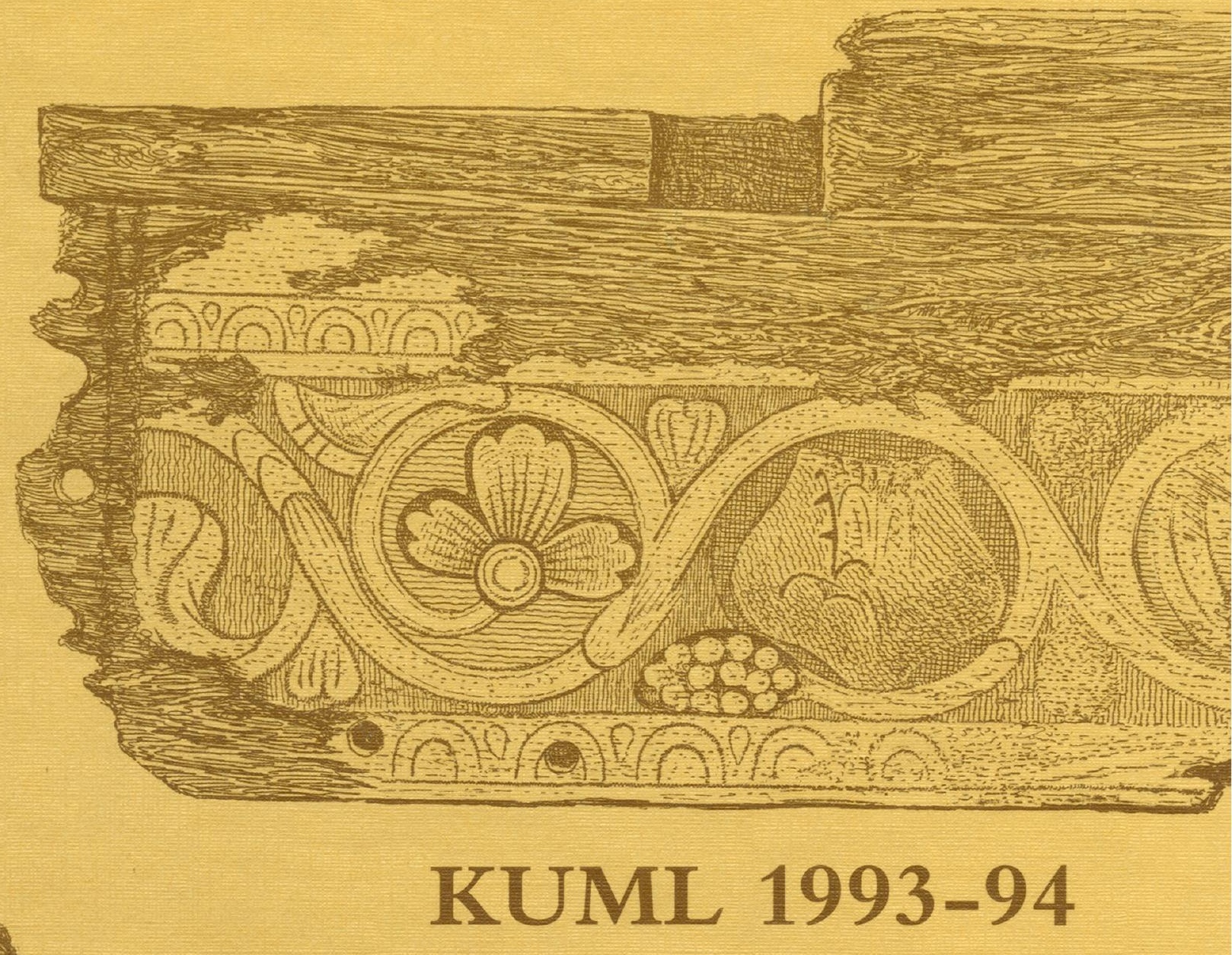




\section{KUML 1993-94}

Årbog for Jysk Arkæologisk Selskab

With summaries in English 
Redaktion: Hans Jorgen Madsen, Poul Kjarum og Birgit M. Rasmussen

Redaktionsudvalg:

Steen W. Andersen, Haderslev

Jens Henrik Bech, Thisted

Steen Hvass, Vejle

Stig Jensen, Ribe

Erik Johansen, Aalborg

Carsten Paludan-Müller, Randers

Ole Schiorring, Horsens

Lay-out og omslag: Jørgen Mührmann-Lund

Grafisk tilrettelagggelse: Elsebet Morville

Tryk: Narayana Press

Skrift: Bembo 11/12

Papir: $115 \mathrm{~g}$ Artik Silk

Copyright 1996 by Jysk Arkaologisk Selskab

ISBN 87-7288-585-8

ISSN 0454-6245 


\section{Indhold/Contents}

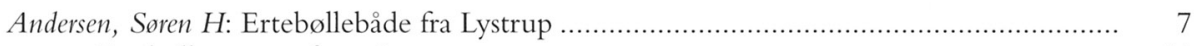

Ertebølle canoes from Lystrup ....................................................................... 36

Ebbesen, Klaus: En jættestue ved Fjersted, Sydvestjylland......................................... 39

A Passage Grave at Fjersted, SW Jutland ................................................... 85

Hansen, Mogens: Træbyggede gravkister fra Enkeltgravskulturen og Senneolitikum ........... 87

Wooden burial cists from the Single Grave Culture and the Late Neolithic .............. 145

Nilsson, Torben: Store Tyrrestrup

En vendsysselsk storgård med bronzedepot fra ældre bronzealder............................ 147

Store Tyrrestrup. A large Early Bronze Age farmstead with bronze hoard .............. 153

Anne-Lonise Haack Olsen og Jens-Henrik Bech. Med bidrag af Svend Th. Andersen,

Pia Bennike, Kjeld Christensen og David Earle Robinson: Damsgård

En overpløjet høj fra ældre bronzealder per. III med stenkiste og ligbrændings-

grube .....

Damsgård. A ploughed-over barrow from Early Bronze Age Per. III with

stone cist and pyre-pit.

Aase Gyldion Andersen: Frugtbarhedsofringer i Sydvestfyns ældre jernalder

Private eller kollektive ofringer?

Fertility Sacrifices in the Early Iron Age of SW Funen. - Private or Collective?..... 210

Torben Egeberg Hansen: Et jernalderhus med drikkeglas i Dejbjerg, Vestjylland .................. 211

Drinking Glasses from an Iron Age settlement from Dejbjerg, West Jutland.............. 237

Mette Iversen og Bjarne H. Nielsen: Brandstrup III.................................................... 239

Grave fra yngre romersk jernalder

Brandstrup III. Graves from the Late Roman Iron Age...................................... 250

Anne Hedeager Krag: Smykkefundet fra Lerchenborg ............................................. 251

Østlige forbindelser i vikingetid

The Lerchenborg Ornaments. Eastern connections in the Viking Age ................ 261

Jens Jeppesen og Holger Schmidt: Rekonstruktion af stavkirken fra Hørning ....................... 263

The reconstruction of the stave church at Hørning ............................................... 275

Bruno Frohlich, Henrik Hjalgrim, Judith Littleton, Niels Lynnerup og Birgitte Sejrsen:

Skeletfundene fra Skt. Peders sognekirkegård i Randers ......................................... 277

Skeletal remains from St. Peder's parish church in Randers .................................. 287

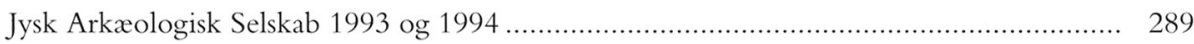




\title{
En jættestue ved Fjersted, Sydvestjylland
}

\author{
Af Klaus EbBesen
}

Jættestuen ligger i Sydvestjylland på den vestslesvigske bakkeø, lige syd for dennes stejle nordskrænt. Fra stedet er der ca. $17 \mathrm{~km}$ mod vest til vadehavskysten ved Hviding og godt $10 \mathrm{~km}$ mod øst til byen Gram (fig. 1). Jættestuen er bygget på den sydlige skråning af en bakkeøkuppel og er omgivet af vandfyldte lavninger. Undergrunden på stedet er gult sand.

\section{Undersøgelsen}

Jættestuen erkendtes først som et oldtidsminde i 1945. Den var ikke synlig på jordoverfladen, men efter anmeldelse fra lodsejeren foretog Hans Neumann, Haderslev Museum, en foreløbig undersøgelse i 1945. Derefter udgravedes anlægget i 1955-59 af Dorthe Ørsnes, Nationalmuseet.

Der gravedes ned oppefra til ca. $1 \mathrm{~m}$ under markens overflade. Derved blev den eneste bevarede dæksten frilagt og toppen af 5 bæresten i kammeret kom til syne. Ligeledes anedes bærestenene i gangen. Anlægget kunne erkendes som en jættestue (fig. 2 og 5-6).

I udgravningsfeltets vægge sås tydeligt en større, moderne nedgravning, som havde ødelagt den vestlige del af kammeret. Fylden i nedgravningen var meget mørk og iblandet trækul. De endnu resterende bæresten i den vestlige del af kammeret var sodsværtede og stenenes overflade var flere steder afsprængt. I fylden lå tillige sprængstykker fra de manglende side- og dæksten.

Den ene, bevarede dæksten fjernedes for at give plads til undersøgelsen af kammeret. Først undersøgtes kammerets østlige, bevarede halvdel, derefter den vestlige. Fylden i den urørte del bestod af ensartet gul til næsten hvidlig sand, som gradvis gik over i undergrundssandet af samme udseende. Kammerets bund kunne derfor ikke iagttages med sikkerhed. Forstyrrelsen i kammerets vestlige ende gik ikke helt til kammerets bund. De nederste $15-20 \mathrm{~cm}$ af kammerets fyld var også her urørt, og standsporene efter mindst 3 bæresten kunne iagttages.

I forskellige niveauer $\mathrm{i}$ hele kammeret fandtes sten, sandsynligvis indfaldne tørmurs- og pakningssten.

Tæt indenfor bærestenen mod nord og forholdsvis højt fremkom et forholdsvis velbevaret lårben og en hofteskål (fig. 7). De øvrige skeletdele, som iagttoges i kammeret, var derimod ret dårligt bevaret (fig. 3). Kun ét sted lå knoglerne sådan, at de kunne stamme fra samme skelet.

Forholdsvis højt i kammerets østlige del fandtes en dobbeltøkseformet og en spoleformet ravperle (fig. 3).

I kammeret fremkom derudover størstedelen af tre lerkar. En tragtskulderskål lå sammentrykket med bunden opad lige indenfor gangmundingen (fig. 3). 


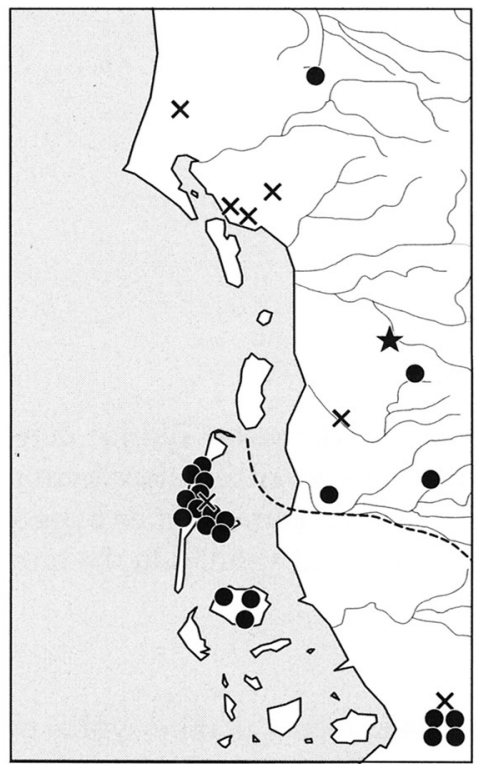

jættestuer

$X$ mellemneolitiske

offerlag

j jættestuen

ved Fjersted

Fig. 1. Jættestuer (punkter) og mellem-neolitiske offerlag (krydser) i Sydvestjylland. Jæettestuen ved Fjersted er angivet med en stjerne.

Passage graves (dots) and Middle Neolithic offering layers (crosses) in SW Jutland. The Fjersted passage grave is indicated by an asterisk.

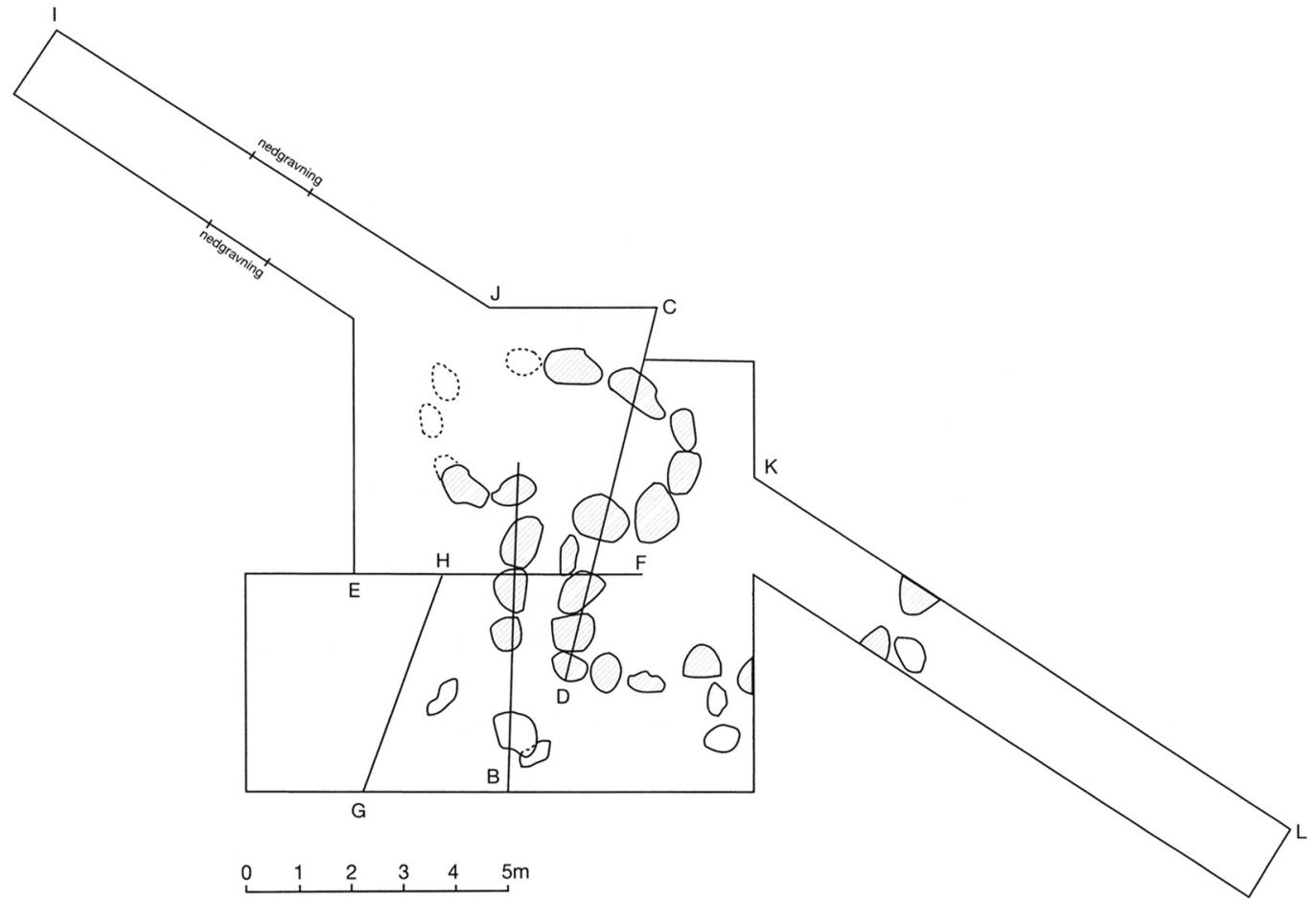

Fig. 2. Plan over udgravningsfeltet.

Plan of the excavation. 


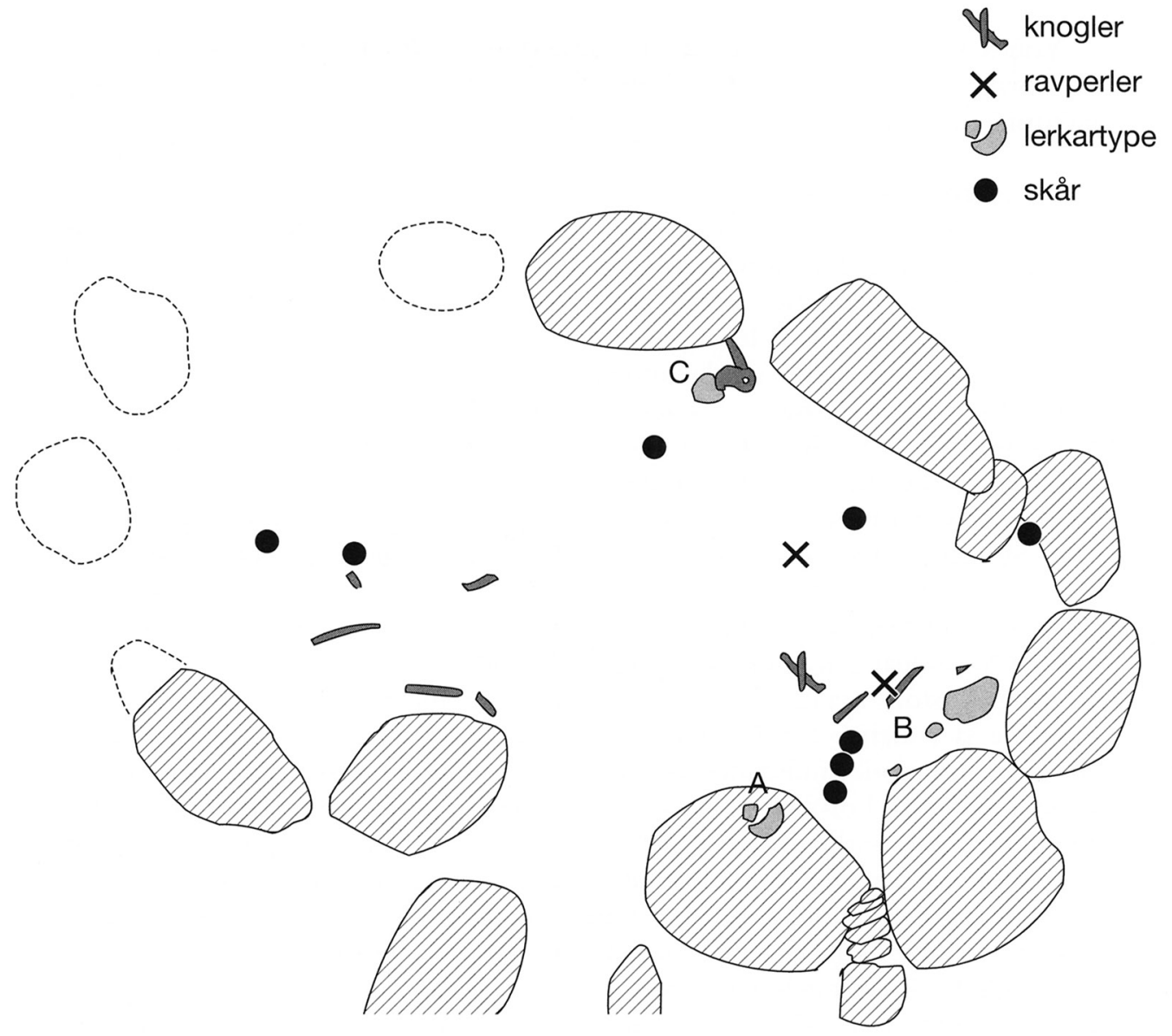

Fig. 3. Grundplan af kammeret med fundene indtegnet.

Plan of chamber showing location of finds.

Længere mod vest i kammeret og i nogenlunde samme niveau fremkom størstedelen af et tøndeformet lerkar, mens skårflagen af en uornamenteret, åben skål lå ved de nogenlunde velbevarede skeletrester mod nord i kammeret.

I kammeret fremkom derudover enkelte, spredte lerkarskår i meget forskellige niveauer. Højdeforskellen var indtil 0,6 m, idet fundene generelt lå højere i den østlige end $i$ den vestlige del af kammeret. Enkelte af skårene indgår i lerkar, som er fundet i offerlagene, vest for indgangen (kat. nr. 20-21 og muligvis 3). De er sandsynligvis tilfældigt kommet ind i kammeret i forbindelse med dettes brug.

Gangen undersøgtes sammen med kammeret. Fylden var ganske som i kammeret og uden lagdeling, og heller ikke her kunne bundniveauet konstateres med sikkerhed. En del hånd- til hovedstore sten, der lå spredt i fylden, er formentlig indskredne pakningssten. En større, aflang sten, der lå på tværs af gangen mellem det inderste par bæresten, skal muligvis opfattes som en tærskelsten, trykket ud af leje af den indskredne, østlige bæresten. 
Yderst var gangen lukket med en ophobning af hovedstore sten (fig. 8), og en større, ret flad sten, der lå udenfor denne stendynge og tildels ovenpå stenpakningen, er sandsynligvis den oprindelige lukkesten i randstenskæden.

Udenom både kammerets og gangens bæresten fandtes en pakning af håndtil hovedstore sten, iblandet en del ubrændt flint (fig. 4a-c og fig. 15). Mod øst og nord iagttoges udenfor kammeret spredte stenlægninger. Stenpakningen om kammer og gang gik endvidere $\mathrm{i}$ et med en uregelmæssig stenlægning, som strakte sig foran gangmundingen og et godt stykke til begge sider for denne. Stenene i stenlægningen lå nogle steder i et kompakt lag, andre steder mere spredt. I og under denne stenlægning fandtes en del lerkarskår.

Øst for gangen var bevaret 6 sten, hvoraf de 4 stod på en række, der sandsynligvis indgår i en randstenskæde. Der lå stenlægninger både foran og bag denne randstensrække (fig. 2), og umiddelbart foran og bag de to randsten nærmest gangen blev der fundet store grupper af lerkarskår (fig. 12) samt enkelte spredte skår. Skårene lå dels over, dels under stenlægningen. En anden skårgruppe lå syd for randstenskæden. Den fremkom på et sted, hvor sandet var rødbrændt og iblandet en del trækulstumper.

Vest for indgangen kunne ikke iagttages randsten eller spor deraf. Her fandtes til gengæld store mængder lerkarskår både over, mellem og under stenlægningen. De lå i mange tilfælde indenfor et afgrænset område (fig. 10-11). Disse skårkoncentrationer indmåltes, mens de fleste andre lerkarskår blot blev optaget kvadratmetervis. Foruden lerkarskår blev også fundet en tværpil og to ravperler. En næsten hel lerske (kat. nr. 20) samt fragmenter af en fodskål (fig. 9a-b), fremkom vest for gangen under stenpakningen bag gangens bæresten.

Som nævnt ovenfor var selve gangmundingen lukket af en stenpakning. Foran denne fandtes kun spredte sten samt forholdsvis fă lerkarskår.

Som led i undersøgelsen anlagdes en ca. $12 \mathrm{~m}$ lang og 1,5 m bred grøft mod øst i kammerets længderetning samt en 9,5 m lang og 1,5 m bred grøft mod vest, ligeledes i kammerets længderetning. Grøfterne blev ført ned til den urørte undergrund. I grøften mod øst fremkom ca. $4 \mathrm{~m}$ fra kammeret ialt 3 sten; de to sandsynligvis opretstående randsten. I den vestlige grøft sås en nedgravning ca. 4,25 m fra kammerets vestende. Det svarer til afstanden fra kammeret til stenene i den østlige grøft og er sandsynligvis spor efter opgravede randsten. Den oprindelige høj har således været mindst $15 \mathrm{~m}$ i diameter.

I de to grøfters profiler fremstod den oprindelige overflade som en mere eller mindre sammenhængende, mørkegul grusstribe. Enkelte steder iagttoges ovenpå denne et mørkt muldlag, som antagelig er det gamle muldlag. Det kunne således i profilerne erkendes, at jættestuens kammer har været gravet ned i undergrunden.

\section{Anloggsbeskrivelse}

Jættestuen (fig. 2) ligger i den sydlige del af en lav høj, opkastet af sand direkte på den gamle markoverflade. Højen har været omsat af randsten, hvoraf 6 registreredes ved højens sydøstlige side. Jættestuens kammer er gravet ca. 0,6-0,8 m ned i det lyse, gule undergrundssand. Gulvet i gangen skråner sandsynligvis fra markoverfladen ned til dette niveau. 

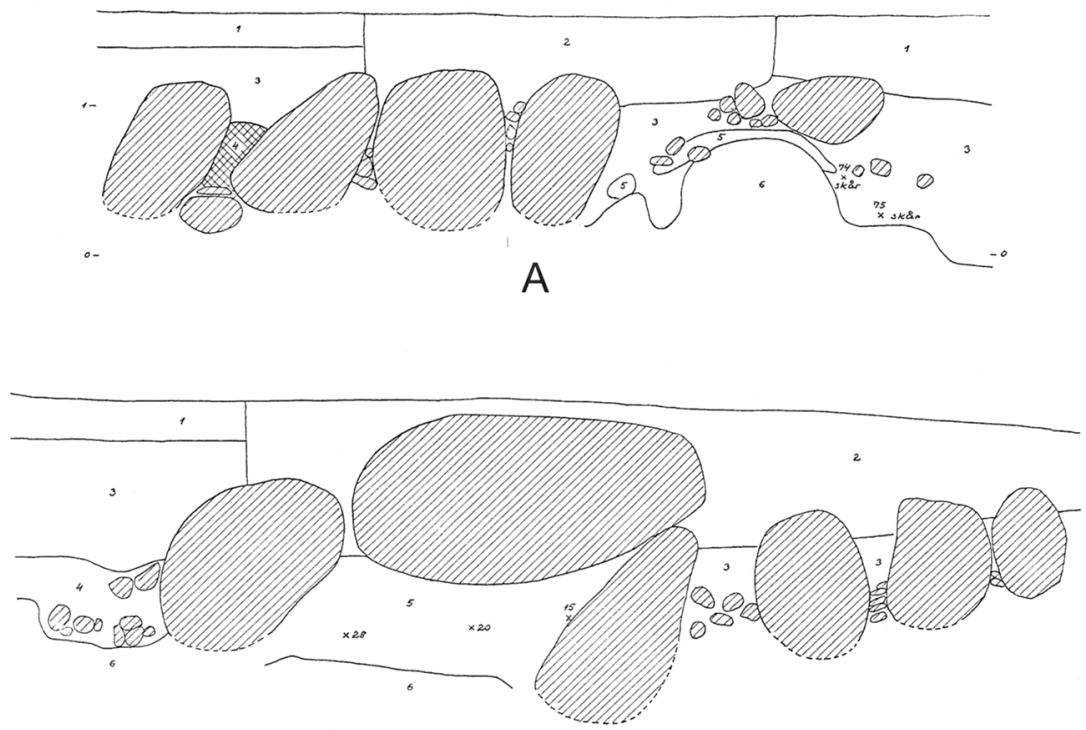

$\mathrm{B}$
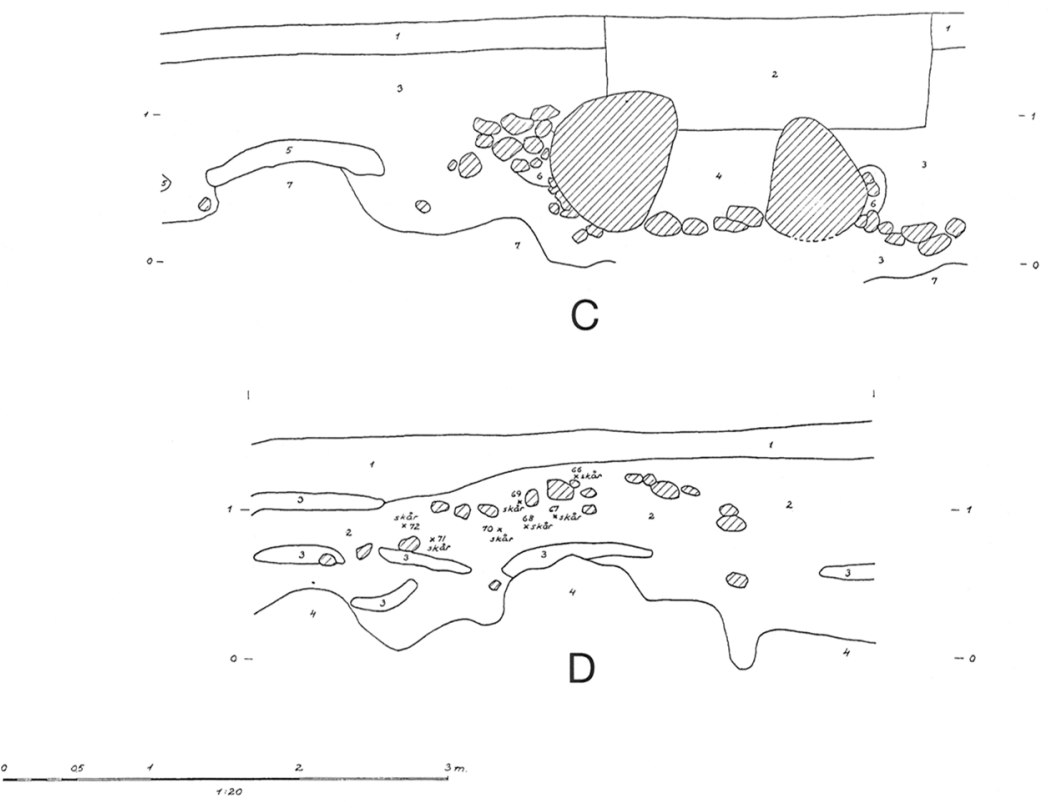

Fig. 4. Snit gennem højen og offerlaget. A. På langs af gangen på dennes vestlige side. B. På tværs af kammeret og på langs af gangen ved dennes østlige side. C. På tværs af gangen ved 2. par bæresten. D. På tværs af offerlaget, vest for gangmundingen.

Sections through the mound and offering layer. A: down western side of the passage. B: across chamber and down eastern side of passage. C: across passage at the second pair of uprights. D: through offering layer W of passage entrance. 


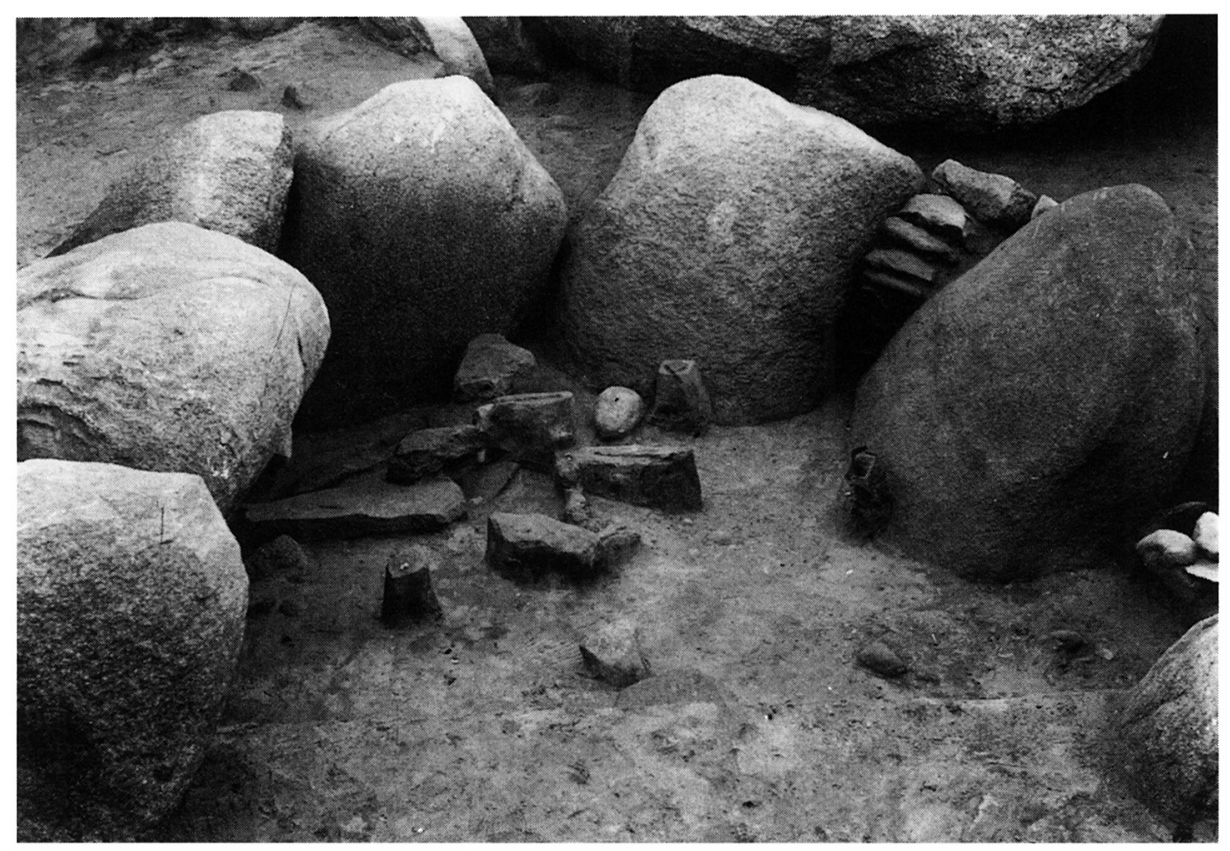

Fig. 5. Anlægget med dæksten set fra sydøst.

View from SE with capstones.

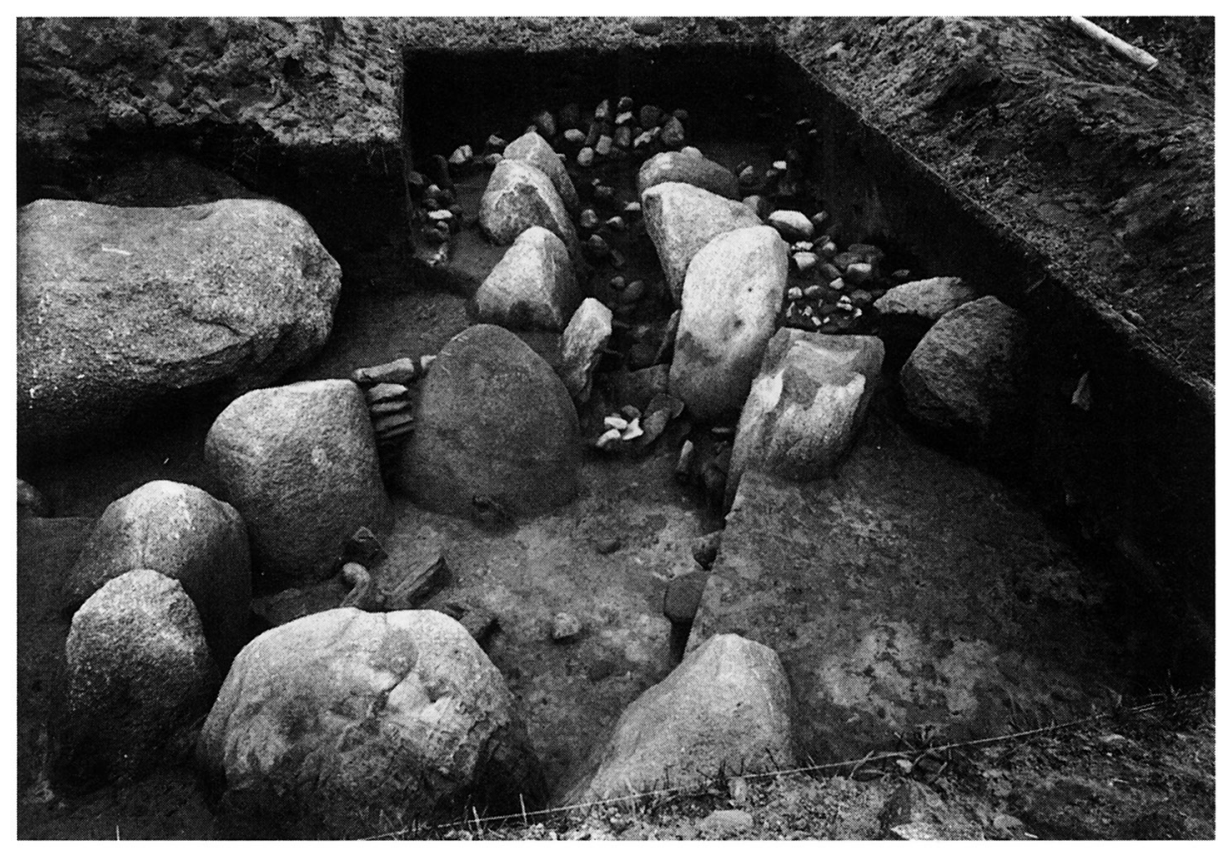

Fig. 6. Anlægget set fra nordvest.

View from NW. 


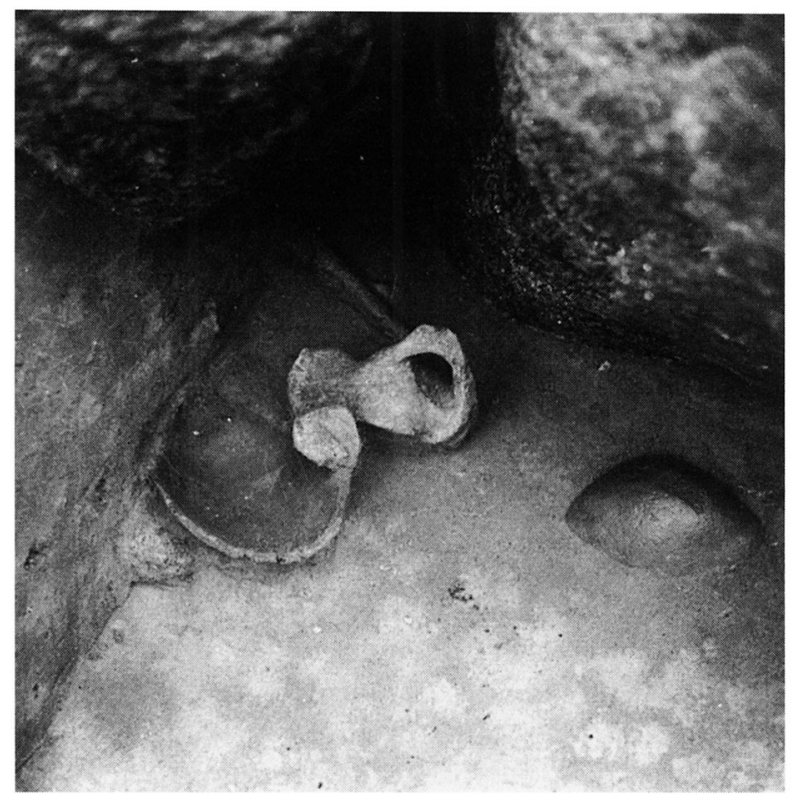

Fig. 7. Skeletrester og skårflage ved kammerets nordlige side.

Human bones and pottery near $\mathrm{N}$ side of chamber.

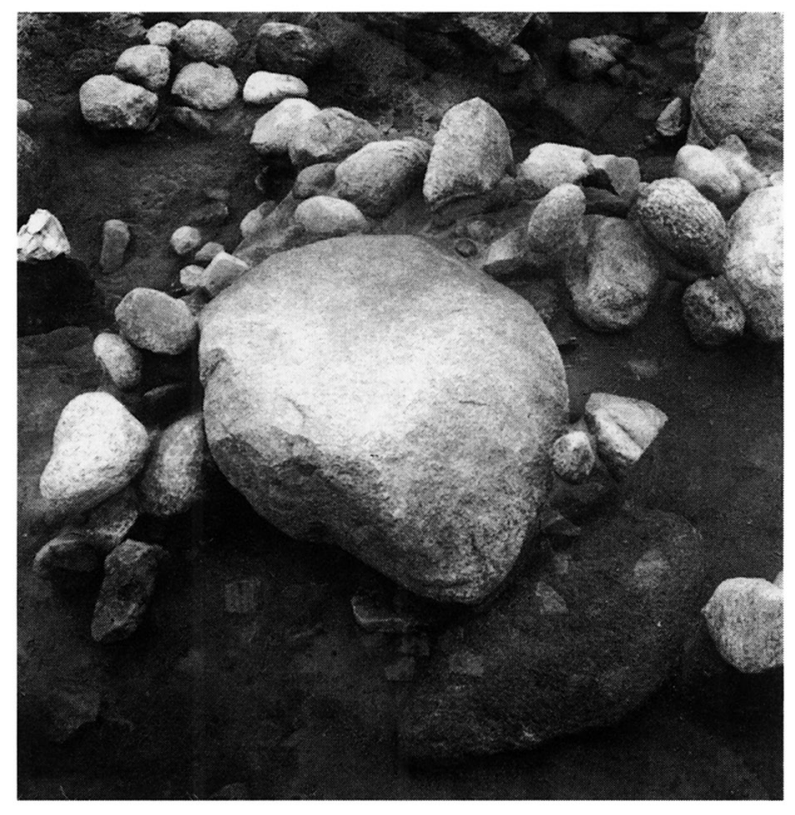

Fig. 8. Stenpakningen ved gangmundingen.

Stone packing at passage entrance. 
Kammeret (fig. 3) har oval grundplan. Det er orienteret $\varnothing-\mathrm{V}$ og har oprindeligt været ca. 3,8 m langt, 1,8 m bredt og 1,1-1,3 m højt. Det har været bygget af 11 bæresten, hvoraf de 8 var bevaret ved undersøgelsen. De resterende 3 bæresten i kammerets vestlige ende var sprængt, men standsporene sås tydeligt $\mathrm{i}$ det lyse sand. En del af de andre bæresten var ligeledes bortsprængt. Ved undersøgelsen hældede alle bærestenene lidt mod sydøst som følge af kammerets sammenstyrtning. Ligeledes var den eneste, bevarede dæksten forskubbet mod sydøst og derved gledet ned i kammeret. Den var ca. $80 \mathrm{~cm}$ tyk. Oprindeligt har kammeret haft 3 dæksten, som lå på tværs af kammerets længderetning.

Mellem bærestenene fandtes forneden rester af en lerpakning, og imellem to af bærestenene øst for indgangen var bevaret tørmur, ligesom mellem de inderste sten i gangen og kammerets bæresten (fig. 13-14). Hverken i kammer eller gang iagttoges noget gulv.

Gangen udgår fra midten af kammerets sydlige langside. Den er ca. $3 \mathrm{~m}$ lang og ca. $0,6 \mathrm{~m}$ bred. Der er bevaret 3 bæresten på vestsiden og 4 bæresten på østsiden, hvoraf de inderste bæresten $\mathrm{i}$ vestsiden og de yderste $\mathrm{i}$ østsiden hælder en del indad. Højden af disse bæresten aftager fra en højde på 0,7 ved gangens udmunding til 1,2 m ved indgangen til kammeret, idet gangens bundniveau, som nævnt, skråner nedad mod det forsænkede kammergulv. Muligvis har der været en tærskelsten mellem det inderste par bæresten. Dæksten var ikke bevaret.

Rundt om både kammer og gang fandtes en pakning af hånd- til hovedstore sten iblandet en del ubrændt flint (fig. 15). Pakningen nåede ind mod bærestenene i en højde af ca. 0,5 m og skrånede derfra nedad, væk fra bærestenene. Pakningen var noget uregelmæssig og ikke lige kompakt overalt og gik i et med en uregelmæssig stenlægning, der strakte sig foran gangmundingen og et godt stykke ud til siderne af den. Under stenpakningen ved gangens yderste bæresten fandtes lerkarskår.

\section{Begravelser $i$ kammeret}

Som nævnt var jættestuen stærkt ødelagt, men dens bundlag var intakt. Her fremkom en del knoglefragmenter, samt et lille antal oldsager. Knoglerne var så fragmenterede, at de dødes antal ikke kan bestemmes. Gravgodset omfatter en dobbeltøkseformet og en spoleformet ravperle (fig. 16,3,2 ), der kun kan dateres til mellemneolitisk tid generelt (2) og tre lerkar: en tragtskulderskål, som kan dateres til MN II (fig. 16,6), ét tøndeformet lerkar (fig. 16,8), som sandsynligvis skal dateres til MN V, samt skårflagen af en uornamenteret, åben miniatureskål (fig. 16,7), muligvis fra samme tid (3).

Der kan således dokumenteres mindst 2 begravelser i jættestuen, henholdsvis i MN II og MN V. Antallet af begravelser har sandsynligvis været betydeligt større, idet man må regne med, at anlægget også har været brugt til begravelser $\mathrm{i}$ hvert fald i MN Ib.

Stendyngen foran indgangen, som blokerede denne og lukkede for adgangen til jættestuen skal sandsynligvis sættes $i$ forbindelse med den seneste begravelse og dateres til MN V. Efter de tidligere begravelser har anlægget sandsynligvis været lukket ved randstenskæden med den flade lukkesten, som fandtes i sekundært leje foran indgangen. 


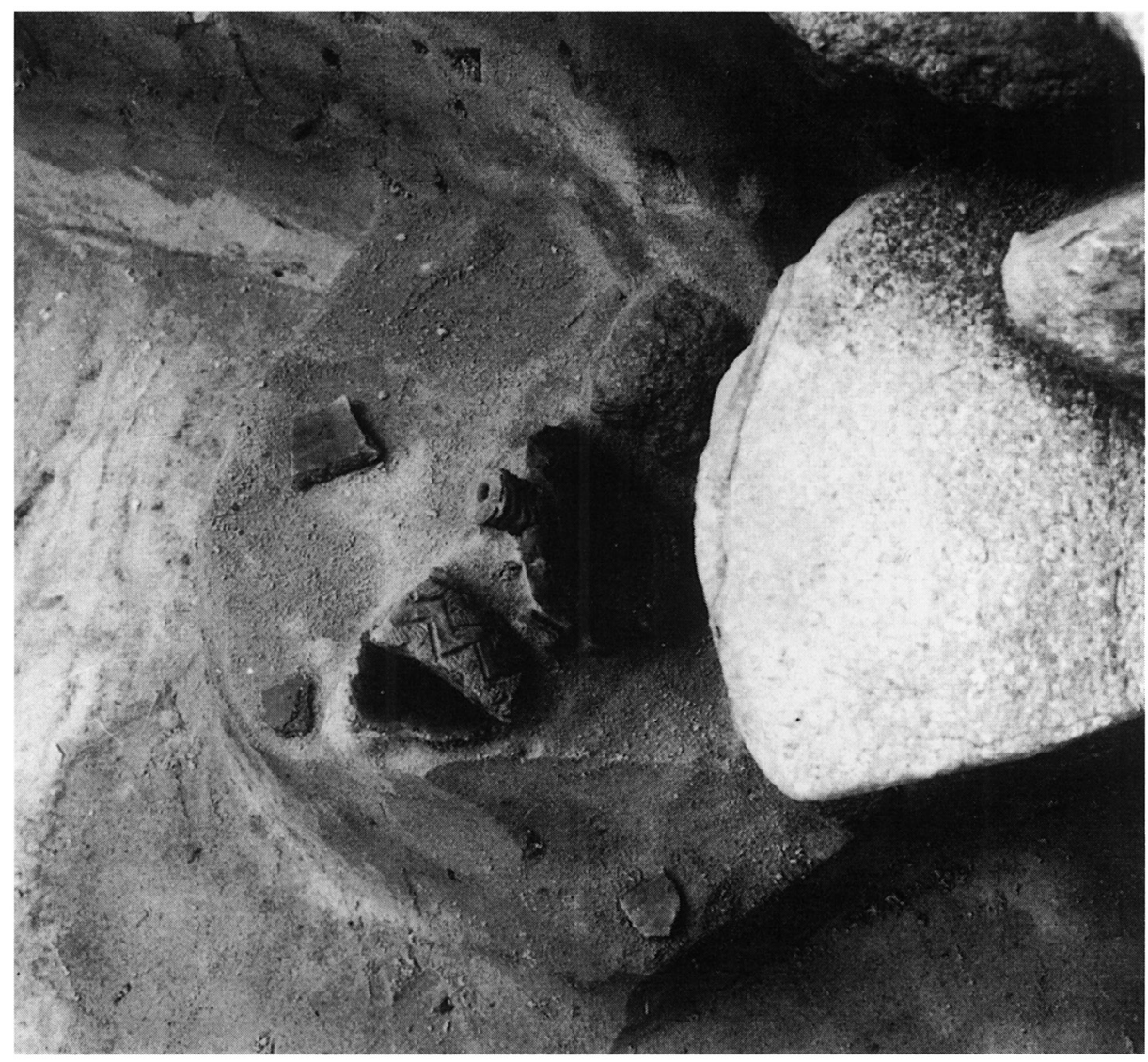

Fig. 9a-b. En lerske og fragmenter af en fodskål, fundet under gangens ydre stenpakning mod vest.

A clay spoon and parts of a pedestal bowl from under the western part of the outer packing of the passage.

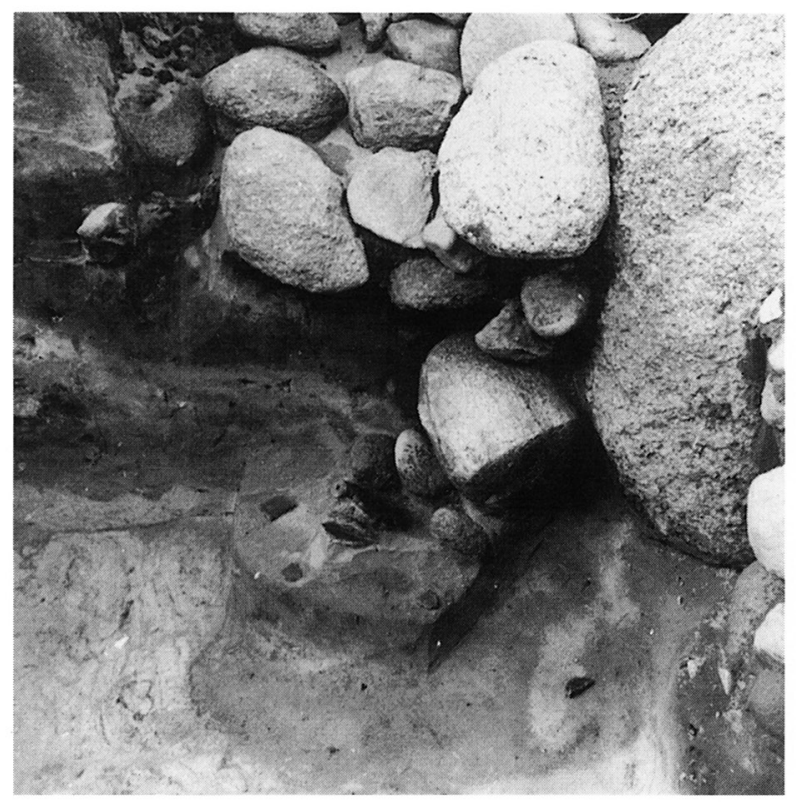




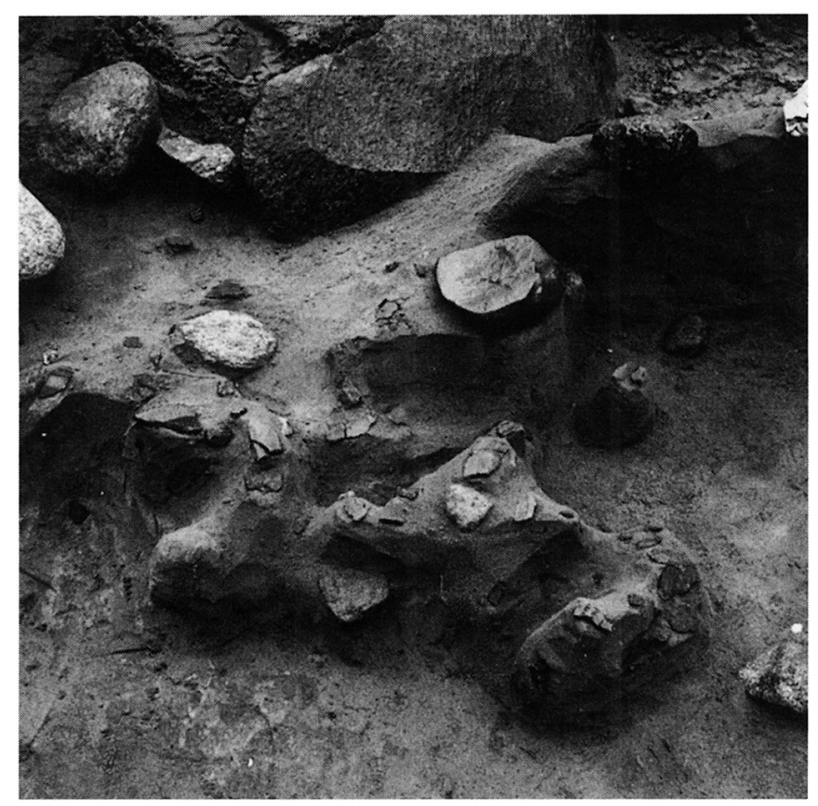

Fig. 10. En større skårgruppe i offerlagets sydlige udkant. Set fra sydøst. Concentration of sherds near southern margin of offering layer, from SE.

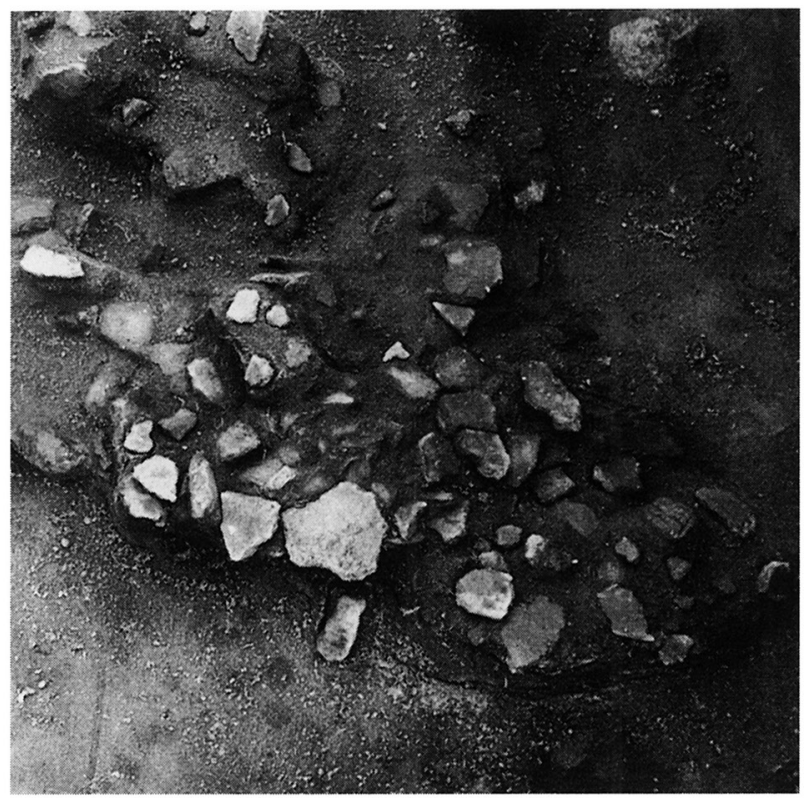

Fig. 11. En større skårgruppe foran randstenene på højens vestside. Set fra nordvest.

Concentration of sherds in front of kerbstones of western side of the mound, from NW. 


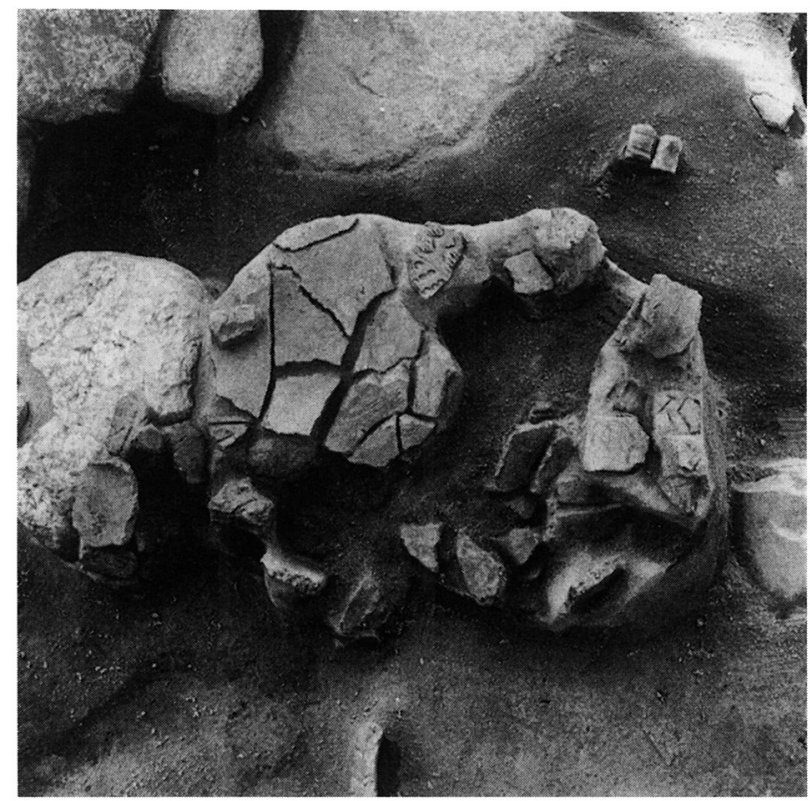

Fig. 12. En større skårgruppe bag randstenene øst for gangen. Set fra nordøst.

Concentration of sherds behind the kerbstones east of the passage, from NE.

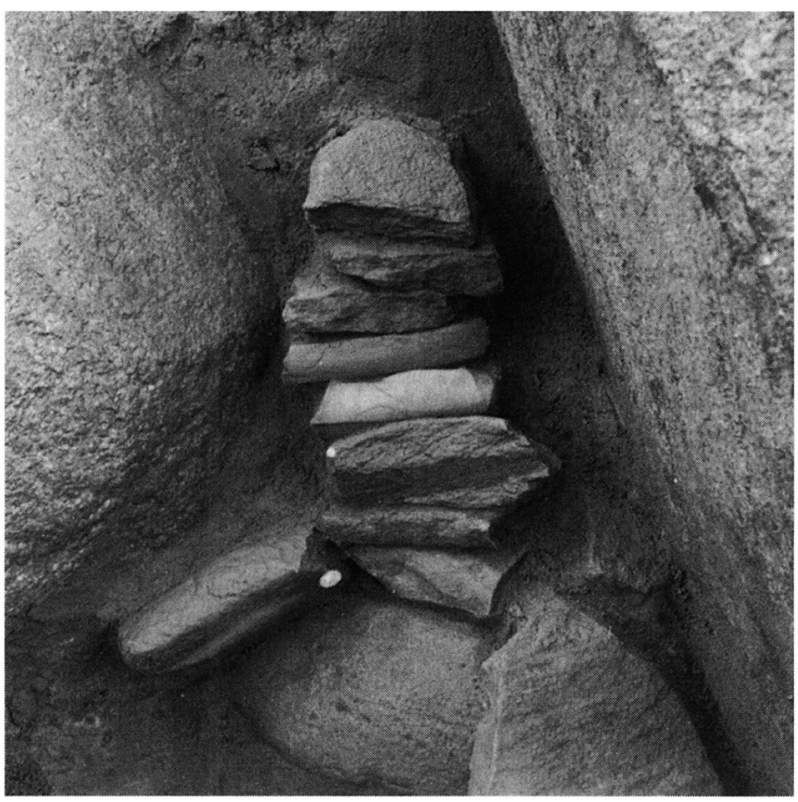

Fig. 13. Tørmurskonstruktion mellem sidestenene i kammerets østende. Dry walling between the uprights of the eastern end of the chamber. 


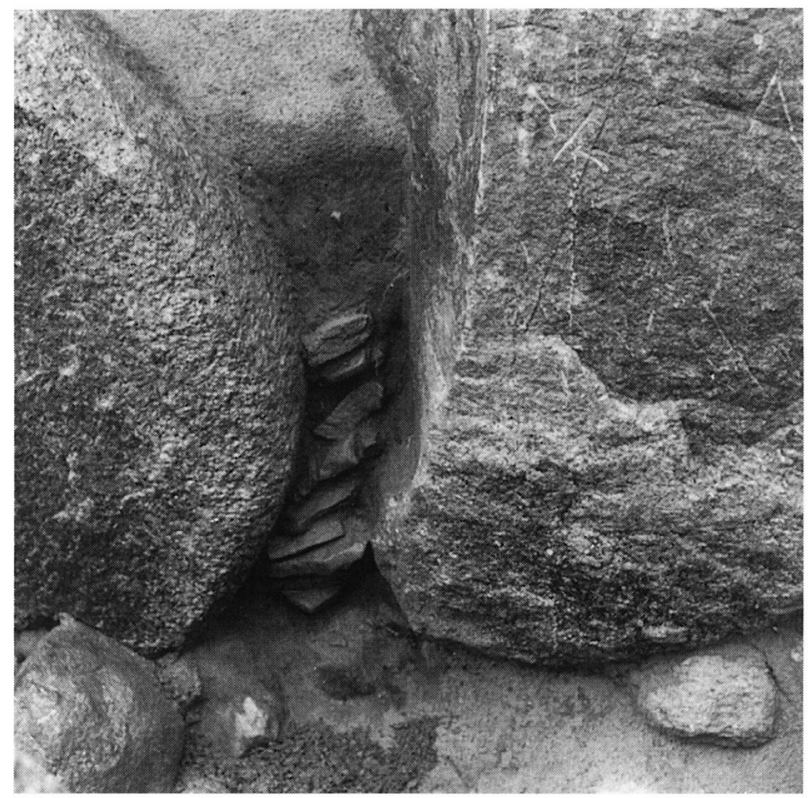

Fig. 14. Tørmurskonstruktion mellem gangens bæresten.

Dry walling between passage uprights.

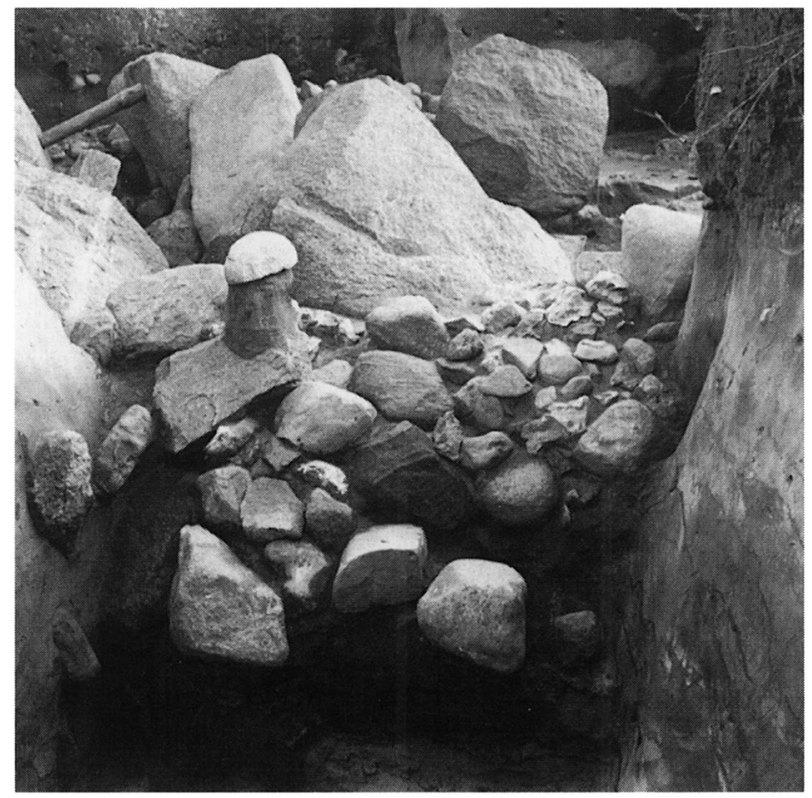

Fig. 15. Stenpakning bag kammerets bæresten.

Stone packing behind chamber uprights. 


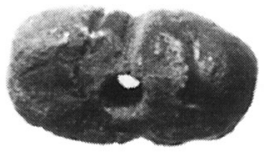

1

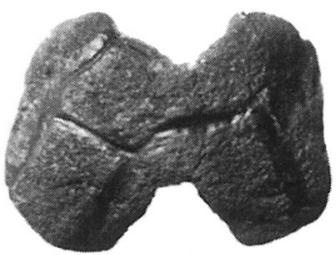

3

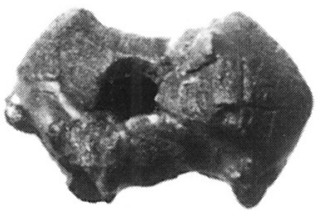

2

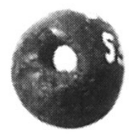

4

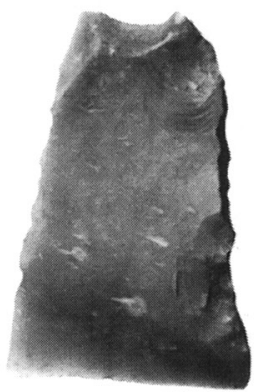

5

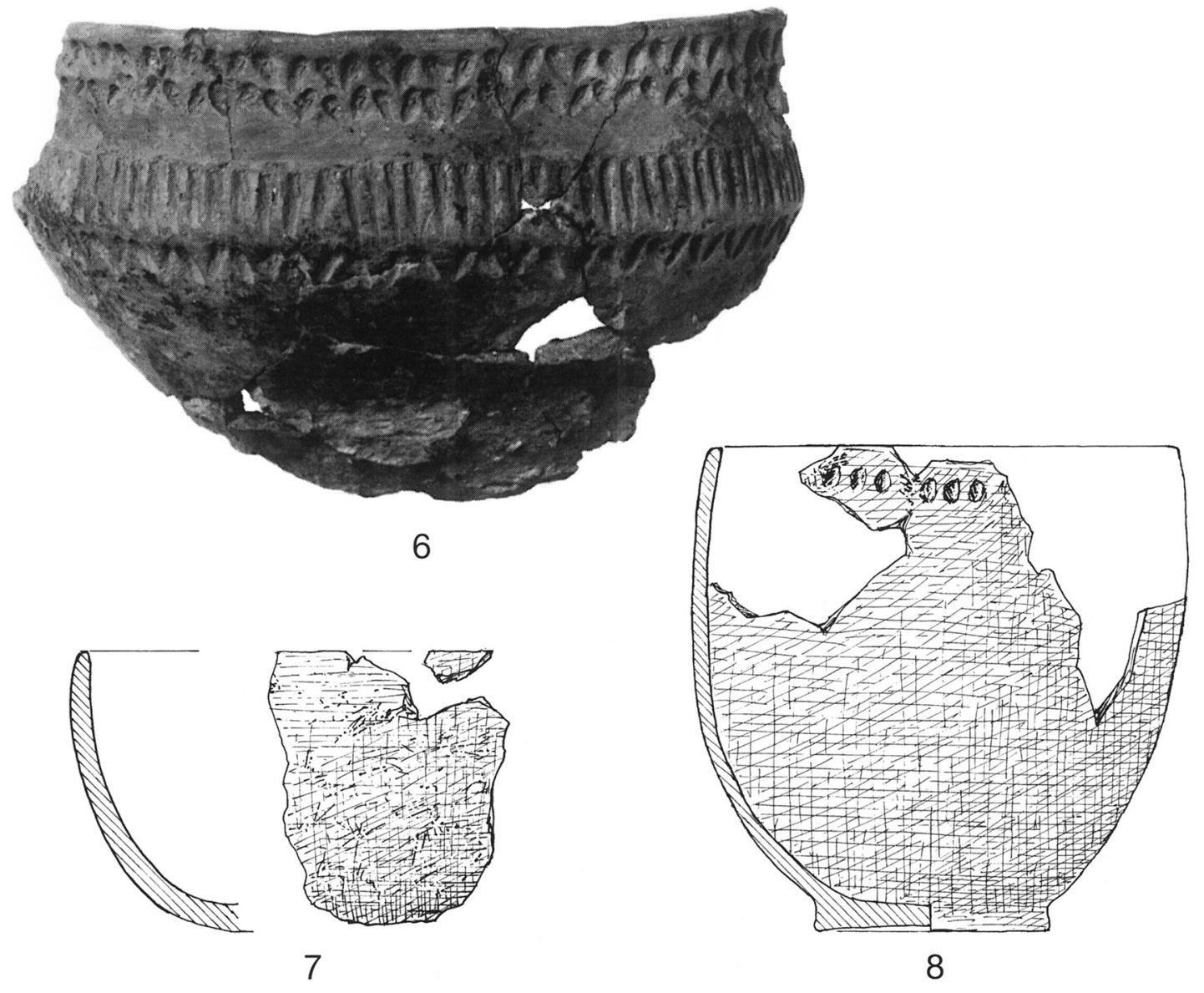

Fig. 16. Lerkar (6-8) og ravperler (1 og 3) fra kammeret samt ravperle og tværpil fra offerlaget (4-5). 2:5.

Pottery (6-8) and amber beads ( 1 and 3 ) from the chamber, and amber beads and transverse arrowhead from the offering layer (4-5). 2:5. 


\section{Offerlaget}

På anlæggets sydlige side fremkom et mindre offerlag, næsten udelukkende af keramik. Enkelte skår fandtes under gangens stenpakning, men størstedelen fremkom i et område umiddelbart sydvest for gangmundingen (fig. 17-25). Skårene lå både foran og bagved randstenene, og skårlaget foran randstenene var - navnlig vest for indgangen - dækket af et kompakt stenlag. I og over dette stenlag fandtes udover keramikken også en tværpil og to ravperler (fig. 16,2, 4-5).

Skårene under gangens stenpakning kan antyde, at keramik er blevet deponeret på stedet før jættestuen er blevet dækket af højen, men hovedparten har efter fundforholdene at dømme været opstillet på eller foran randstenene.

Offerlaget indeholdt resterne af mindst 51 forskellige lerkar og keramiske produkter (tabel 1).

Tabel 1. Keramikken i offerlaget.

15 Fodskåle

3 Lerskeer

3 Skulderkar

5 Troldebjergskåle

1 øskenbæger

10 Tragtbægre

4 Tragtskåle

1 Cylinderhalsbæger

2 Bægre med konkav hals

1 Sfærisk skål

5 Lerskiver

1 Ubest. lerkar
(14 MN Ib og $1 \mathrm{MN}$ I/II )

(alle MN Ib)

(1 MN Ib, $1 \mathrm{MN}$ II og $1 \mathrm{MN}$ I/II )

(4 MN Ib, 1 MN II)

(MN Ib)

(1 MN Ib, 1 MN II, 6 MN I/II og 2 udat.)

(1 MN Ib, 2 MN II, 1 MN I/II)

(MN I/II)

(begge udat.)

(Udat.)

(1 MN I/II og 4 udat.)

( MN II ) 


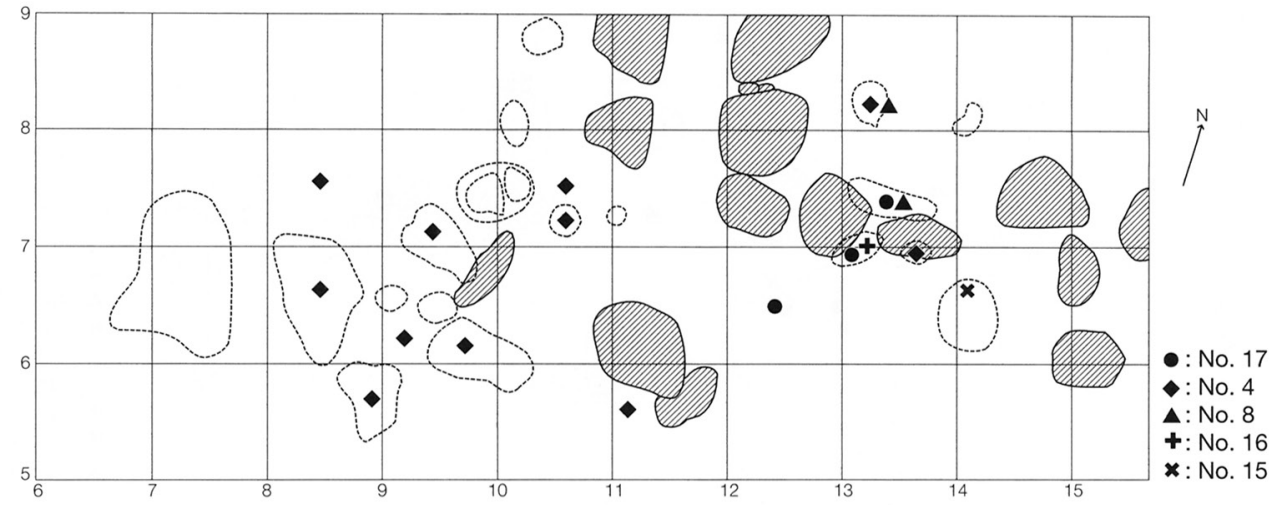

Fig. 17. Spredningen af fodskåle, dateret til MN Ib.

Distribution of pedestal bowls dated to $\mathrm{MN} \mathrm{Ib}$.

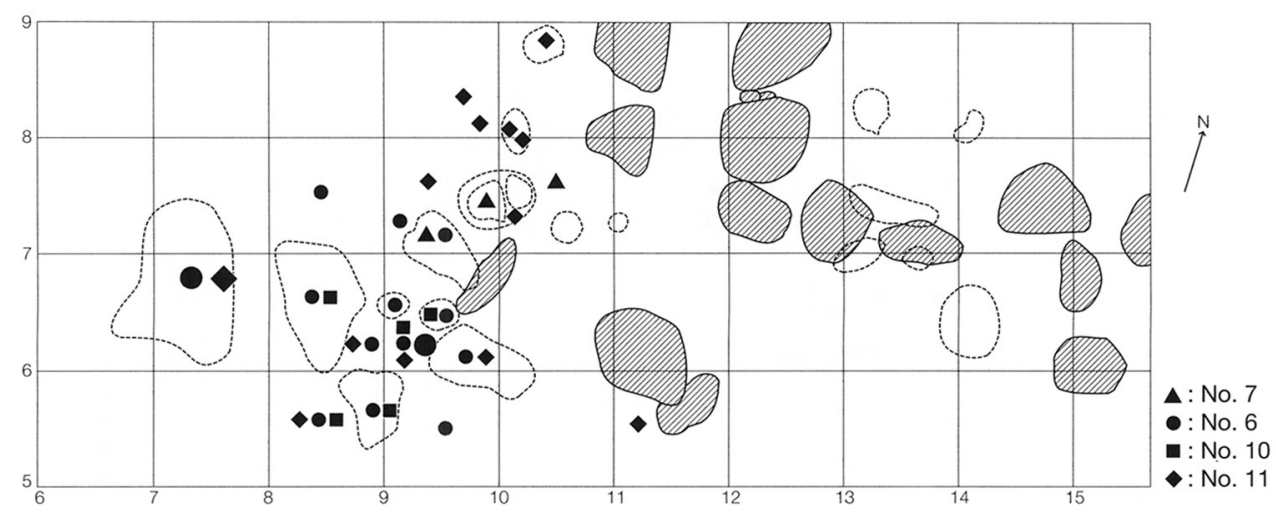

Fig. 18. Spredningen af fodskåle, dateret til MN Ib.

Distribution of pedestal bowls dated to MN Ib.

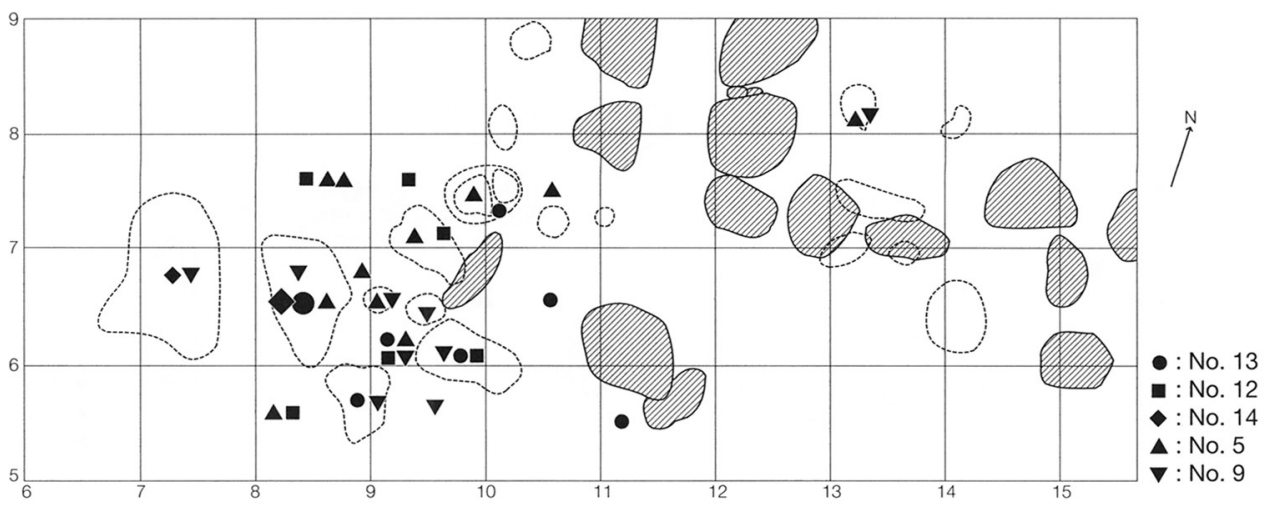

Fig. 19. Spredningen af fodskåle, dateret til MN Ib.

Distribution of pedestal bowls dated to MN Ib. 


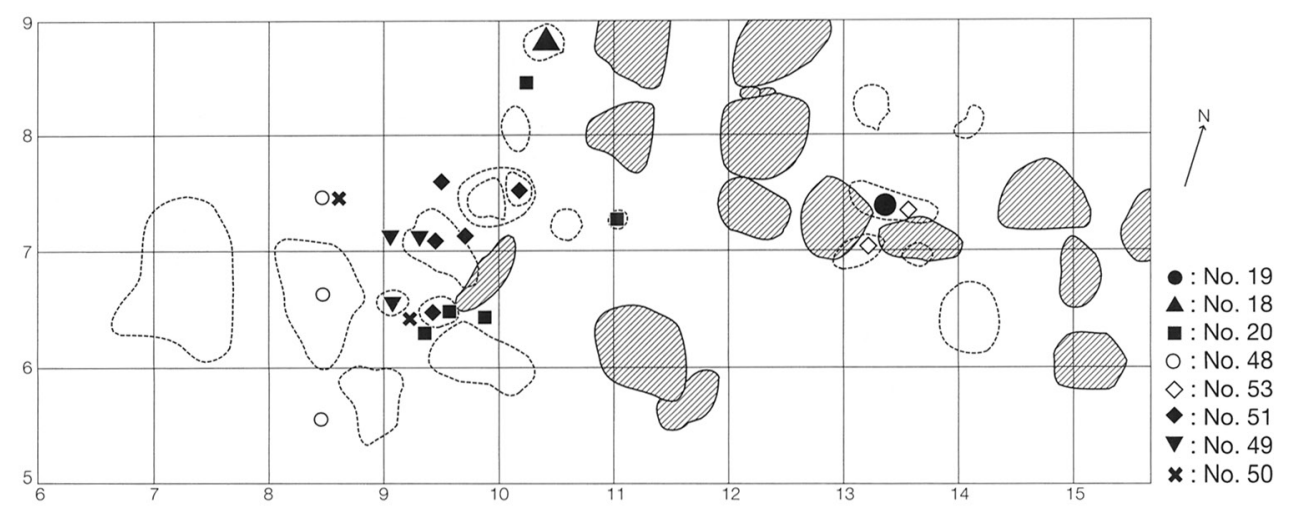

Fig. 20. Spredningen af skår fra lerskeer, lerskiver og en sfærisk skål.

Distribution of sherds of clay spoons, clay discs, and a spherical bowl.

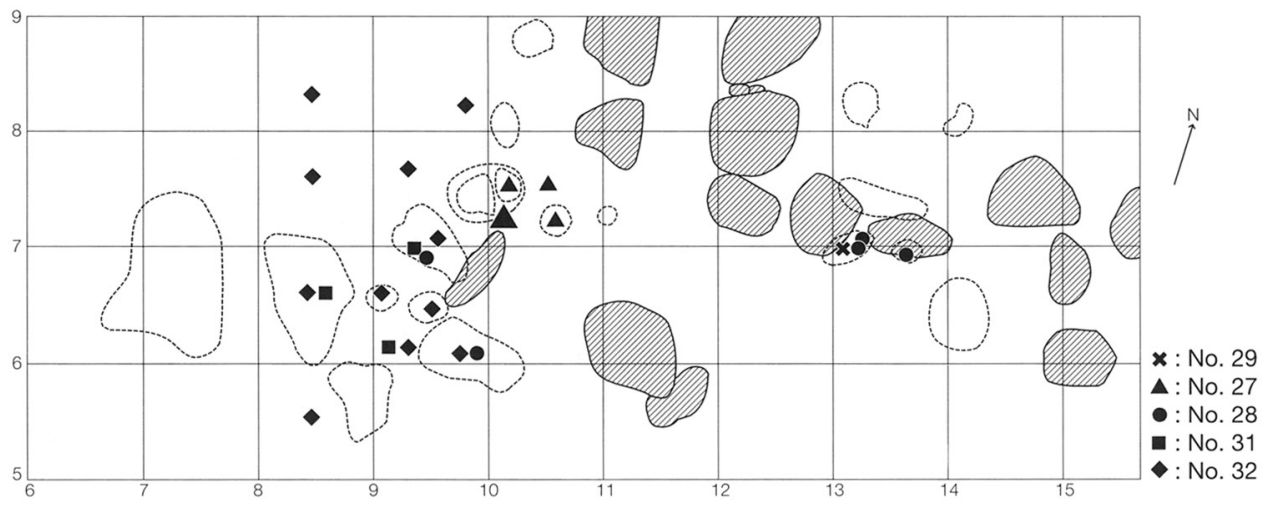

Fig. 21. Spredningen af skulderkar og tragtskåle.

Distribution of shouldered vessels and funnel bowls.

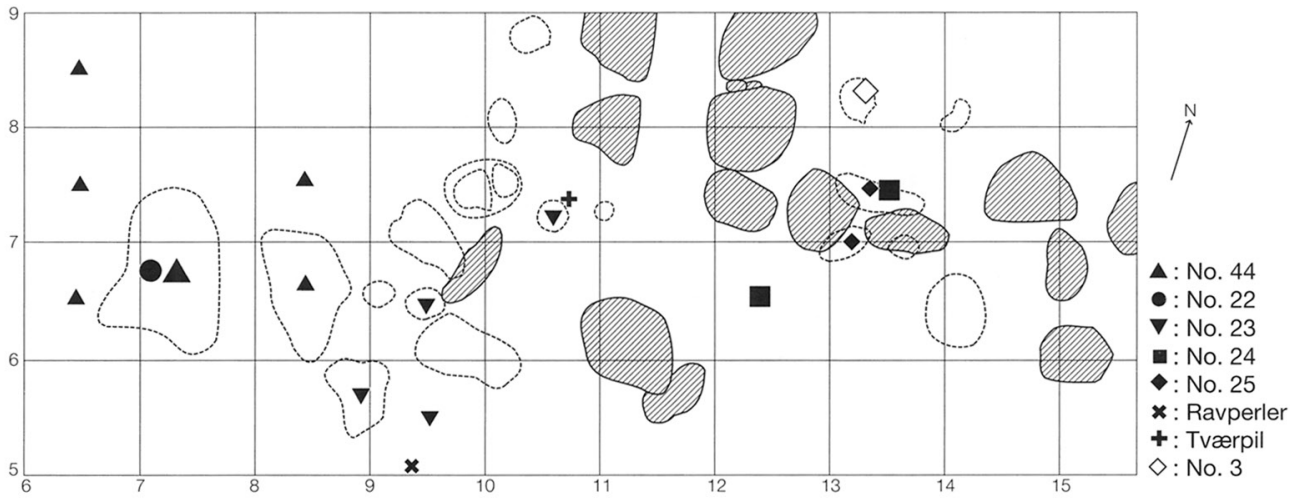

Fig. 22. Spredningen af Troldebjergskåle (dateret til MN Ib), en fodskål og et øskenbæger.

Distribution of Troldebjerg bowls (dated to MN Ib), a pedestal bowl, and a lugged beaker. 


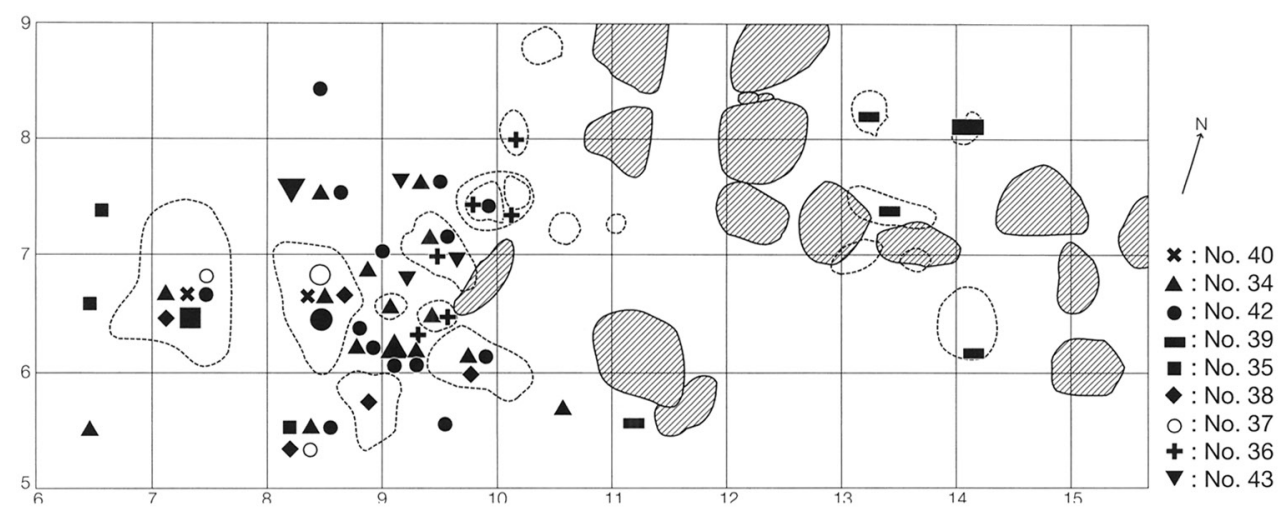

Fig. 23. Spredningen af tragtbægre.

Distribution of funnel beakers.

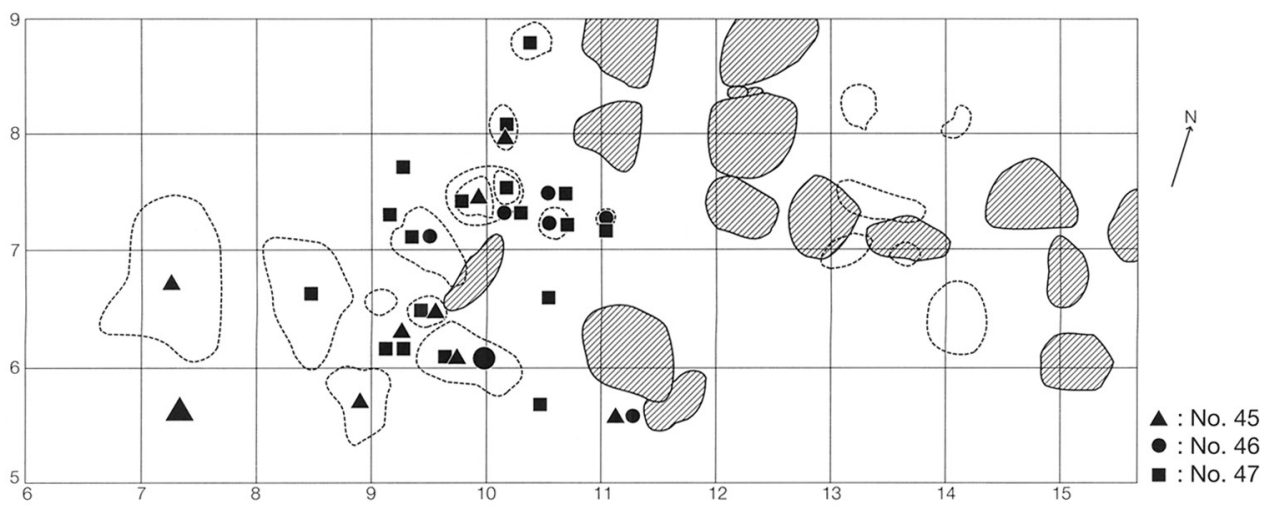

Fig. 24. Spredningen af et cylinderhalsbæger og bægre med konkav hals.

Distribution of a cylindrical neck beaker and beakers with concave necks.

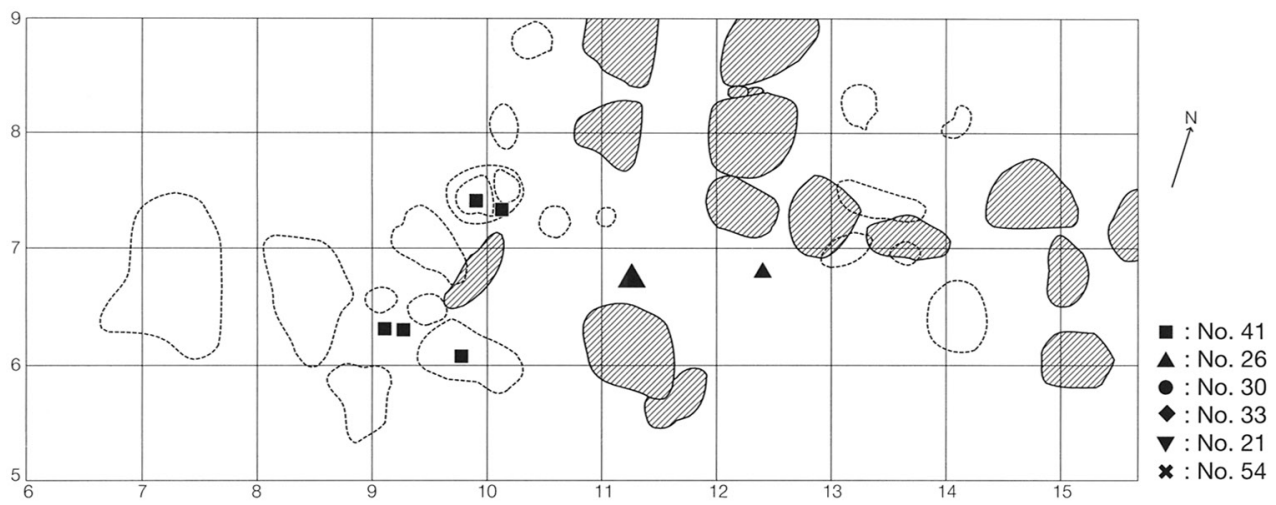

Fig. 25. Spredningen af keramik, som kan dateres til MN II.

Distribution of pottery datable to MN II. 


\section{Fodskåle}

Fodskålene var med mindst 15 kar den dominerende lerkarform.

En af fodskålene (fig. 27,1) har en ekstremt lav, ca. $3 \mathrm{~cm}$ høj fod og kun plastisk antydede øskner. Den er ornamenteret med vinkellinier, kommastiklinier og vinkelbånd. Den kan dateres til MN I/II og fandtes på den oprindelige jordoverflade (?), ca. $1 \mathrm{~m}$ bag randstenene øst for gangmundingen (fig. 22).

De øvrige fodskåle har alle haft almindelige proportioner. Skåldiametren varierer fra ca. 25 til $40 \mathrm{~cm}$, mens foddiametren ligger omkring $20 \mathrm{~cm}$. De har haft to, modstående hanke mellem fod og skål, for så vidt antallet af hanke kan bestemmes. De fleste stykker har en særlig ornamentik ved hankene, som det er almindeligt på fodskåle.

De fleste fodskåle er ornamenteret med vandrette rækker af halvbuestik, men vinkellinier og kommastiklinier er også repæsenteret. På to af fodskålene er ornamentikken endvidere afgrænset af linier udført med beviklet snor. Ikke mindre end 14 af de 15 fodskåle kan således stilistisk dateres til MN Ib. Hverken Troldebjerg- eller Blandebjergstilenes særlige karaktertræk forekommer på nogle af fodskålene.

Fragmenterne af 4 fodskåle er kun fundet øst for gangmundingen (fig. 17). Den ene af disse (fig. 33,4) er ornamenteret med vandrette, udfyldte vinkelbånd. En anden fodskål (fig. 31,8), hvis skår fandtes både foran og bag randstenene er på foden ornamenteret med fladedækkende mønstre af vandrette linier i beviklet snor. Mønstret afgrænses mod hankene af lodrette vinkelrækker.

Mellem 1. og 2. randsten fandtes skårene af en fodskål (fig. 33,1) ornamenteret med vandrette, cardiumudfyldte liniebånd og indrammet af halvbuelinier. Skårene af en stærkt forvitret fodskål (fig. 37,1), der lå foran den 2. randsten, er ligeledes ornamenteret med cardiumudfyldte vinkelbånd.

Skårene af 7 MN Ib-fodskåle fremkom udelukkende vest og sydvest for gangmundingen. Fragmenterne af de fleste kar lå nogenlunde samlet, medens andre var spredt over et større område (fig. 18). Det sidste gælder for yderligere 3 MN Ib-fodskåle, hvor skårene blev fundet både vest og øst for gangmundingen (fig. 18-19). De 9 af disse MN Ib-fodskåle er på skål og fod ornamenteret med et fladedækkende mønster af vandrette rækker af halvbuestik (fig. 27,2; fig. 31,5 og 9 samt fig. 33,7) eller kommastiklinier (fig. 28; fig. 31,7; fig. 32; fig. 34,6 og fig. 37,2). På en enkelt fodskål (fig. 33,3) ses vandrette linier. Ornamentikken ved og på hankene er sædvanligvis lodret-orienteret og består på flere af lodrette vinkellinier eller -rækker, eller af liniebundter. Ornamentikken under randen og ved halsfoden omfatter vandrette vinkellinier og -bånd eller hængende og stående trekanter, evt. udfyldt med skrå- eller krydsskravering. Ved overgangen fra skål til fod kan findes en lignende ornamentik af vinkellinier, vinkelbånd eller trekantrækker. 

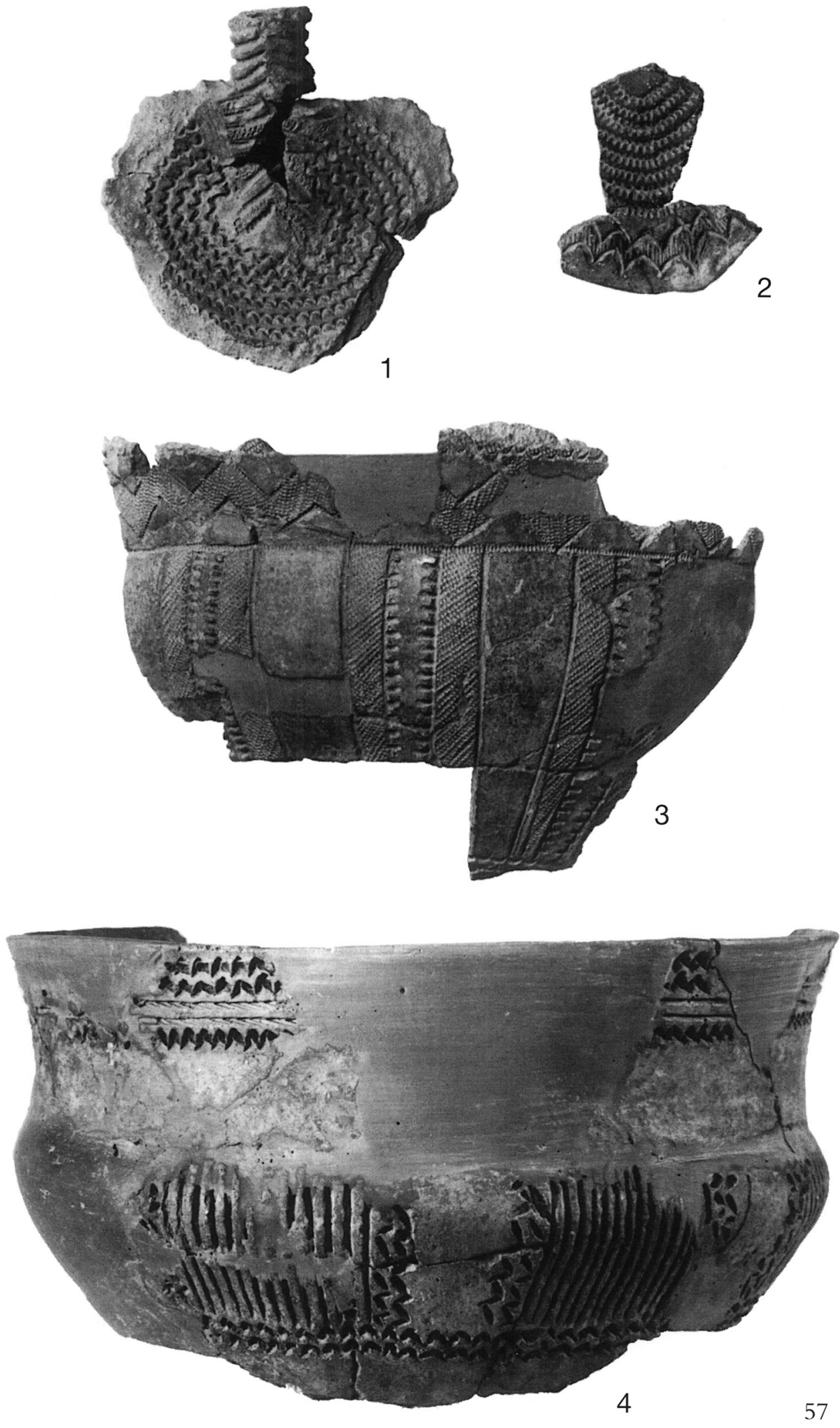


\section{Lerskeer}

Offerlaget omfatter kun 3 lerskeer, som alle kan dateres til MN Ib. De to har rundt blad, og på den ene sidder endnu ved siden af døllen spor af en knop eller et "horn« (fig. 33,2). Den er på horn og dølle ornamenteret med omløbende linier i beviklet snor; på bladet ses afvekslende kommastik- og vinkellinier. Skeen fandtes bag randstenskæden mellem 1. og 2. randsten øst for gangmundingen (fig. 20). Den anden, runde lerske er på døllen ornamenteret med vinkelrækker, ligeledes i beviklet snor, mens der på bladet ses omløbende rækker af halvbuestik (fig. 26,2). Den tilhører muligvis samme pottemagerproduktion som fodskålen (fig. 32), men er fundet under stenpakningen vest for gangen (fig. 20). Den tredje lerske (fig. 26,1) har haft spadeformet blad. Bladet er ornamenteret med omløbende linier i halvbuestik og ved kanten et vinkelbånd. Skårene af denne ske er fundet spredt, sydvest for gangmundingen (fig. 20).

\section{Skulderkar}

Der er kun fremkommet fragmenter af 3 skulderkar i offerlaget. Det ene er en skulderskål (fig. 29,1), ornamenteret med rækker af halvbuestik og vinkellinier under randen, samt lodrette linier i beviklet snor på skulderen. Den kan dateres til MN Ib og fandtes i skår lige vest for gangmundingen (fig. 21). Et andet fragmenteret skulderkar (fig. 37,9) fandtes lige foran indgangen (fig. 25). Det kan dateres til MN II og er på skulderen ornamenteret med hængende trekanter. Af et tredje skulderkar (fig. 31,1) foreligger kun et par halsskår; under randen og ved halsfoden ornamenteret med vinkellinier. De fandtes øst for gangmundingen mellem 1. og 2. randsten (fig. 21). Muligvis repræsenterer en række hals/bugskår et fjerde skulderkar (fig. 34,7). De fandtes stærkt spredt på begge sider af gangmundingen. Karret har været ornamenteret med udskrabede trekanter på skulderen og kan dateres til MN I/II.

Generelt er skårene af de få skulderkar således fundet påfaldende tæet ved gangmundingen, både foran og på begge sider af denne (fig. $21 \mathrm{og} 25$ ).

\section{Troldebjergskåle}

I offerlaget indgår fragmenterne af mindst 5 Troldebjergskåle. De 4 er ornamenteret i Klintebakkestil og kan dateres til MN Ib. Skårene af den ene (fig. 34,3) er fundet samlet, $4 \mathrm{~m}$ vest for gangmundingen (fig. 22). Den er på halsen ornamenteret med et krydsskraveret felt og vinkellinier, mens der på bugen ses lodrette, tredobbelte bånd. Fragmenterne af to Troldebjergskåle er fundet både foran og bagved 1.-2. randsten øst for gangmundingen. De har sandsynligvis været hensat på 1. (eller 2.) randsten mod øst. De er begge ornamenteret med indstemplede vinkellinier på halsen og lodrette, tredobbelte bånd på bugen (fig. 37,7,10). Skårene af en fjerde Troldebjergskål, ornamenteret med vinkellinier og lodrette bånd (fig. 33,8), fandtes stærkt spredt sydvest for gangmundingen (fig. 22). 

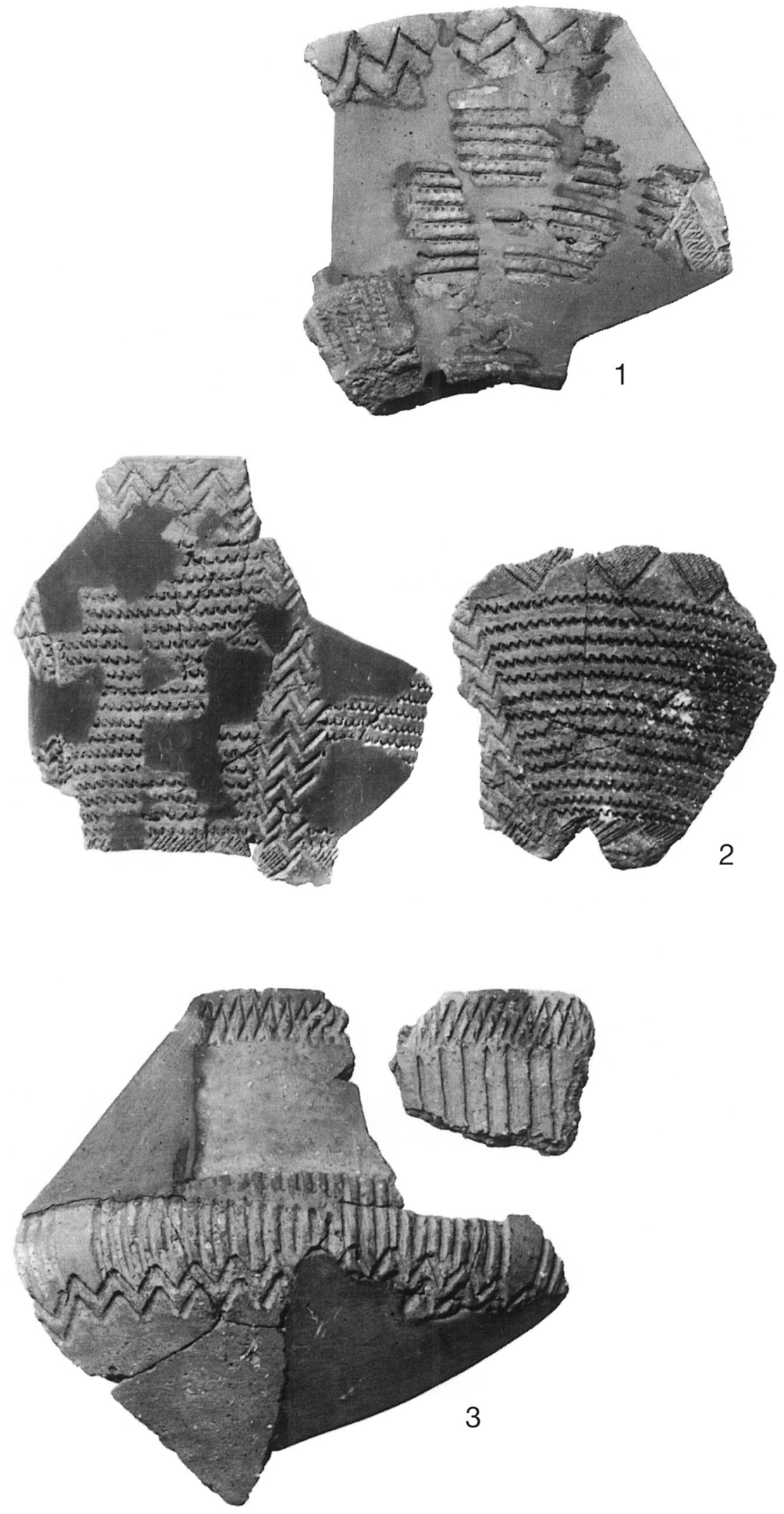


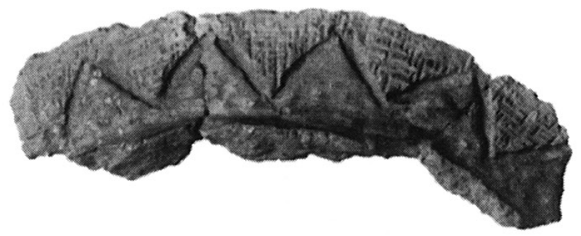

Fig. 28. Fodskål. 2:5.

Pedestal bowl. 2:5.
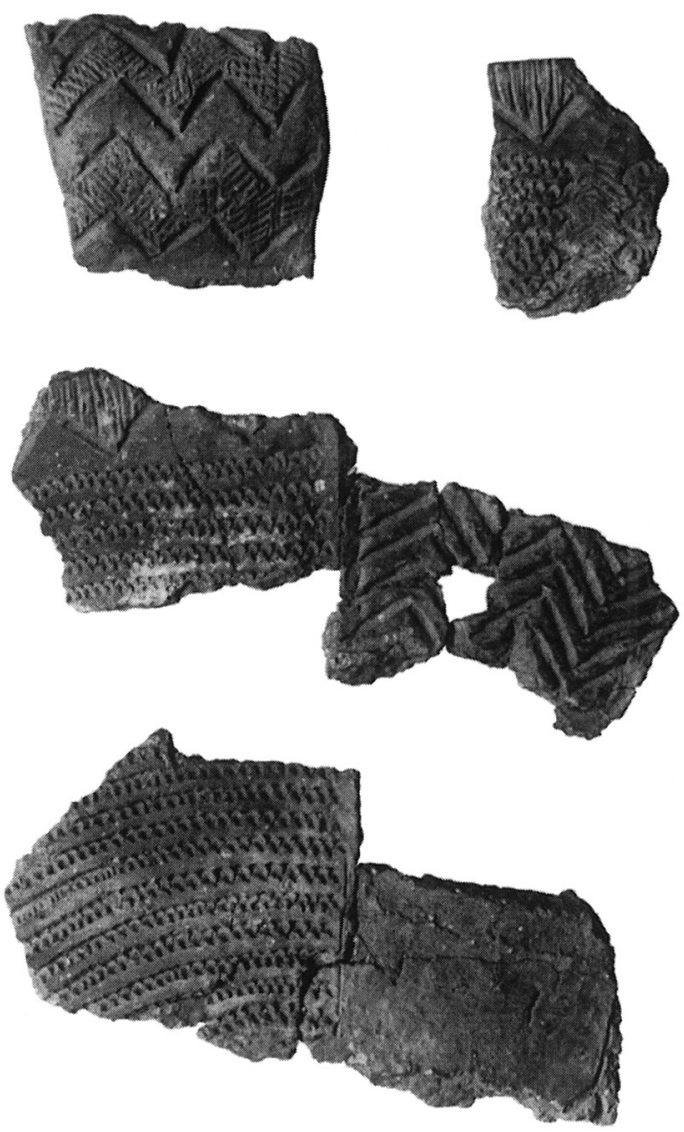

Fig. 29. Skulderskål (1) og tragtbægre (2-3). 2:5.

Shouldered bowl (1) and funnel beakers (2-3). 2:5. $\rightarrow$ 

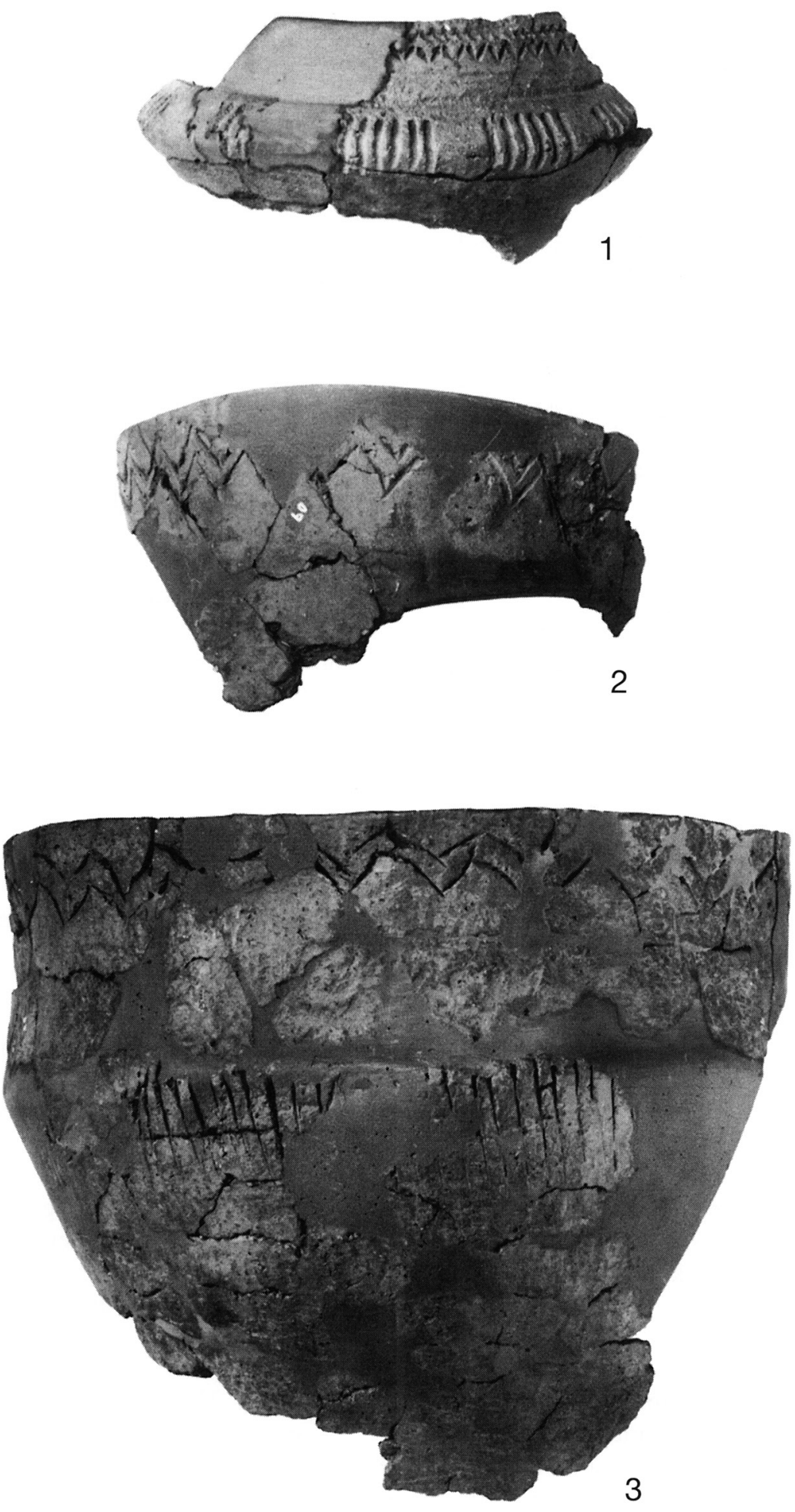
Den sidste Troldebjergskål (fig. 26,3) er forholdsvis velbevaret. Den er ornamenteret i tidlig Ferslevstil og dateret til MN II. På halsen ses et bredt, vandret vinkelbånd, mens der på bugen findes lodrette tredobbelte bånd; det midterste et lynlåsbånd. Skårene af karret er fundet spredt vest for indgangen (fig. 25).

\section{Tragtskåle}

Ved jættestuens front er hensat mindst 4 tragtskåle. Den ene af disse (fig. 34,1) er under randen ornamenteret med en vandret rhomberække, udfyldt med lodrette streger. På den øverste del af bugen ses rækker af halvbuestik og lodrette linier i grov beviklet snor. Karret, der lå spredt ved offerlagets vestlige udkant, kan dateres til MN Ib (fig. 21).

To, forholdsvis velbevarede tragtskåle kan dateres til MN II. På den ene (fig. 27,3 ) ses under randen et krydsskraveret felt; derunder på halsen lodrette liniegrupper, medens bugen er lodret afstribet, nedadtil afgrænset af vandrette vinkellinier. Skårene af den fandtes foran og bag randstenene øst for indgangen (fig. 25). Den anden, omhyggeligt tildannede tragtskål (fig. 26,4) er under randen ornamenteret med et sammensat mønster af vandrette linier og vinkelllinier. På den øverste del af bugen ses lodrette liniegrupper, afgrænset af lodrette dobbeltvinkellinier samt foroven og -neden indrammet af vandrette vinkellinier. Tragtskålen fandtes i spredte skår vest for gangmundingen (fig. 25).

Den sidste, flygtigt tildannede, tragtskål (fig. 33,5) kan kun dateres til MN III. Den er under randen ornamenteret med et krydsskraveret felt; på bugen en lodret afstribning. Skårene af karret fandtes nogenlunde samlet, ca. 4 m sydvest for gangmundingen (fig. 21).

\section{Øskenbagre}

I offerlaget fandtes også fragmenterne af ét rigtornamenteret øskenbæger (et pragtbæger - fig. 36,2). Det kan dateres til MN Ib og er på hals og bug ornamenteret med samme mønster af lodrette, tredobbelte bånd. Skårene fremkom ca. 4 m sydvest for gangmundingen, de fleste på ét sted (fig. 22).

\section{Tragtbagre}

I offerlaget fandtes skår af 10 tragtbægre, hvoraf kun 2 kan opfattes som drikkebægre. Det ene af disse (fig. 37,3) er under randen ornamenteret med lodrette streger og kan dateres til MN Ia/b. Det fandtes sydvest for gangmundingen (fig. 23). Det andet, mindre tragtbæger er udelukkende ornamenteret med en fintandet tandstok i tidlig Ferslevstil (fig. 30,2). Det kan dateres til MN II. Skårene fremkom forskellige steder i den store skårkoncentration sydvest for gangmundingen (fig. 25). De andre tragtbægre er enten store eller mellemstore og repræsenterer »køkkenservicet«.

Et sikkert magnum-tragtbæger er ca. $35 \mathrm{~cm}$ bredt og højt. Det er ornamenteret med vinkellinier under randen og på bugen med den for tragtbægrene almindelige afstribning (fig. 29,3). Det kan dateres til MN I/II. Skårene fandtes stærkt spredt flere meter sydvest for indgangen (fig. 23). Samme ornamentik findes på et lidt mindre tragtbæger (fig. 29,2), som tilhører samme tid, og hvis skår ligeledes fandtes stærkt spredt sydvest for gangmundingen (fig. 23). I det samme område fremkom også størstedelen af et tragtbæger, hvis lodrette bugaf- 

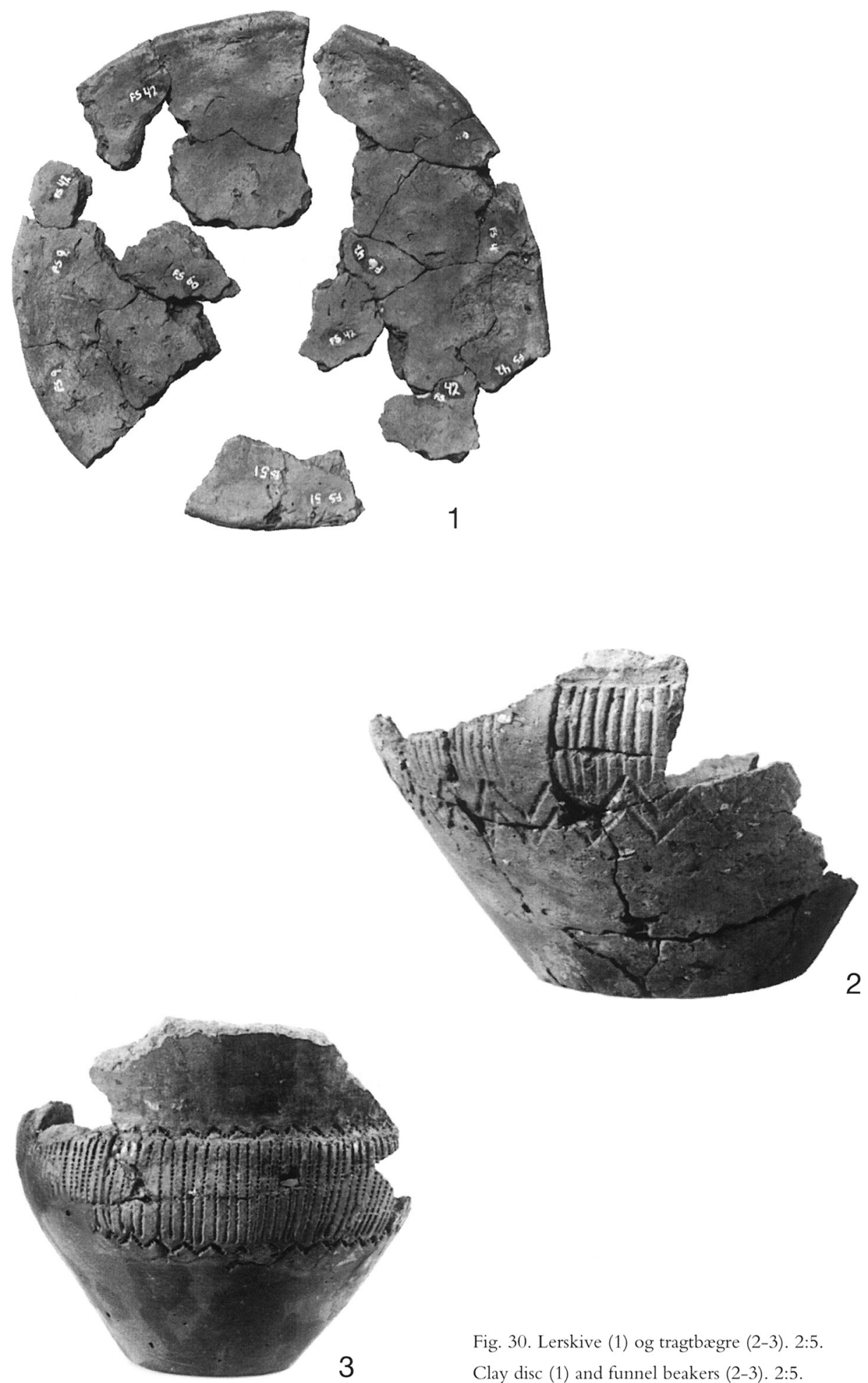

Fig. 30. Lerskive (1) og tragtbægre (2-3). 2:5.

Clay disc (1) and funnel beakers (2-3). 2:5. 
stribning nedadtil afsluttes af en indridset dobbeltvinkellinie (fig. 30,3). Bægret, som har vinkellinier under randen, kan ligeledes dateres til MN I/II.

Ost for indgangen fandtes kun skårene af ét, stort og groft tragtbæger (fig. 36,1). Skårene lå næsten alle bag randstenene (fig. 23). Karret er under randen ornamenteret med en vandret række diffuse indstik og kan dateres til MN I/II. Samme datering gælder for to mellemstore tragtbægre, der under randen er ornamenteret med vandrette rækker af henholdsvis skrå, diffuse indstik (fig. 36,4) og runde gruber (fig. 31,4). Skårene af dem fandtes henholdsvis sydvest og vest for gangmundingen. Her lå også fragmenterne af to uornamenterede, mellemstore tragtbægre (fig. 34,5 og fig. 36,3), som kun kan dateres indenfor tragtbægrenes produktionstid.

Det er karakteristisk, at hovedparten af skårene fra de enkelte tragtbægre fremkom samlet (eller i koncentrationer) på forskellige steder i det store skårlag vest og sydvest for indgangen. Karrene kan således ikke have stået ved siden af hinanden, men har været placeret på forskellige steder indenfor et forholdsvis begrænset område.

\section{Cylinderhalsboeger}

Fundet fra offerlaget omfatter derudover størstedelen af et stort cylinderhalsbæger (fig. 35,2). Det er ca. $40 \mathrm{~cm}$ bredt over mundingen og er revnet ved optørringen. Det er derefter repareret med 2x2 klinkningshuller på overdelen, samt en lille lerflage, lagt over mundingskanten. Mens klinkning af revnede lerkar er almindelig i neolitisk tid, er den tilføjede lerlap over mundingskanten et unikt fænomen. Cylinderhalsbægret er ornamenteret med korte, brede indstik under randen og dybt indstemplede skråstreger på den øverste del af bugen. Det kan dateres til MN I(/II) og er fundet stærkt søndret, men komplet, med en koncentration $4 \mathrm{~m}$ sydvest for indgangen (fig. 24).

Bagre med konkav hals

I offerlaget indgår skårene af mindst 2 store bægre med konkav hals (fig. 34,8 og fig. 35,1). De er begge uornamenterede og kan kun dateres til MN (I/)II. De fandtes begge stærkt spredt vest for gangmundingen (fig. 24).

Sfarisk skål

Der fremkom kun fragmenterne af én sfærisk skål (fig. 37,8). Den er uornamenteret, og skårene fandtes stærkt spredt i offerlagets vestlige del (fig. 20).

\section{Lerskiver}

Fundet omfatter fragmenterne af mindst 5 lerskiver. De er alle ca. $20-25 \mathrm{~cm}$ i diameter og 1-1,5 cm tykke. Den ene (fig. 31,6) er ornamenteret med indstik langs kanten og kan dateres til MN I/II. Skårene af den fandtes på forskellige steder i den store skårkoncentration sydvest for gangmundingen (fig. 20). Her fremkom også noget spredt størstedelen af en velbevaret, uornamenteret lerskive (fig. 30,1). Skårene af en anden, uornamenteret lerskive (fig. 33,9) lå

Fig. 31. Skulderkar (1), tragtbæger (4), lerskive (6), fodskåle (5 og 7-9) samt ubestemmelige lerkar (2-3). 2:5. Shouldered vessel (1), funnel beaker (3), clay disc (6), pedestal bowls (5 and 7-9), and indeterminate pottery (2-3). 2:5. 

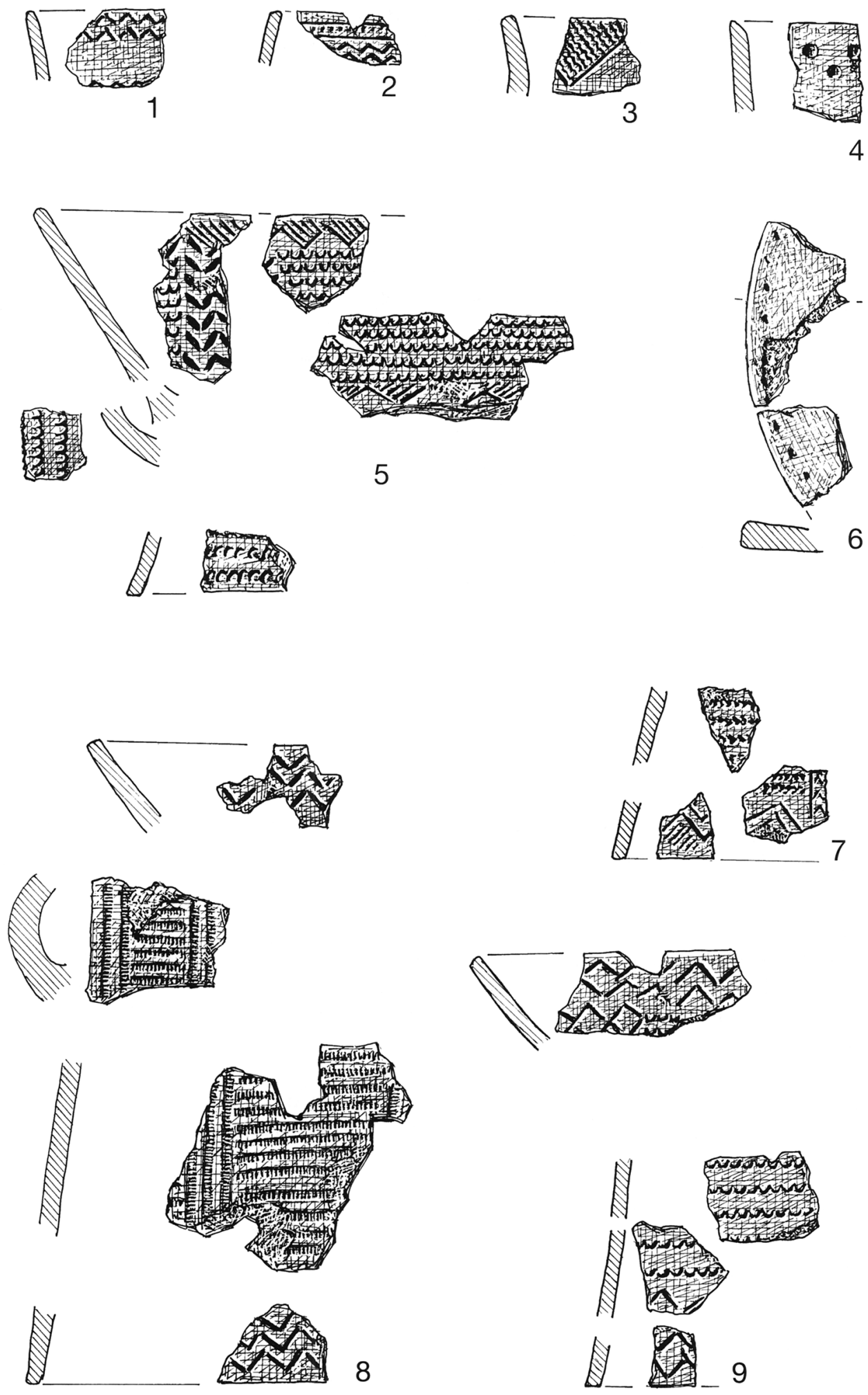


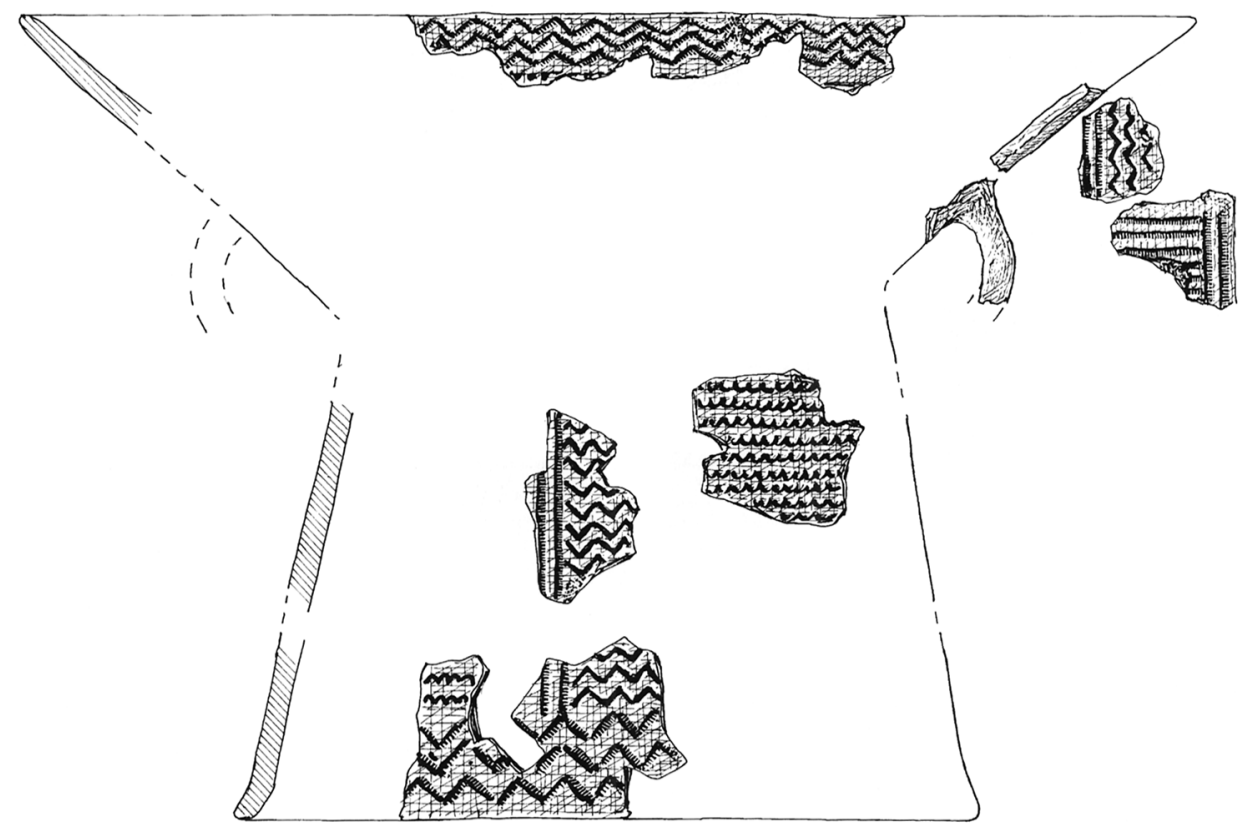

Fig. 32. Fodskål.1:4.

Pedestal bowl. 1:4.

vest for gangen, sandsynligvis der hvor randstenene har stået, mens tre små skår af en fjerde, uornamenteret lerskive lå foran og bag 1. og 2. randsten øst for indgangen. Fragmentet af den sidste lerskive (fig. 37,5) er fundet i profilgrøften mod øst (fig. 20).

\section{Diverse skår}

Herudover er ved indgangen fundet en del ornamenterede og uornamenterede skår fra lerkar, hvis form ikke kan bestemmes. Blandt disse er et randskår (fig. 31,2), ornamenteret med et sammensat, indridset mønster bl.a. i falsk beviklet snor, der kun kendes på dette ene skår, der derfor må repræsentere yderligere et (ubestemmeligt) lerkar. Det kan dateres til MN II.

Derimod kan det ikke afgøres, om nogle af de øvrige skår (fig. 31,3; fig. 34,2; fig. 37,4,6) stammer fra de ialt 51 lerkar, der er beskrevet ovenfor.

Fig. 33. Fodskåle (1, 3-4 og 7), lerske (2), tragtskål (5), Troldebjergskål (8), lerskive (9) og ubestemmelig underdel (6). 2:5.

Pedestal bowls (1, 3-4, 7), clay spoon (2), funnel bowl (5), Troldebjerg bowl (8), clay disc (9), and indeterminate lower body (6). 2:5. 

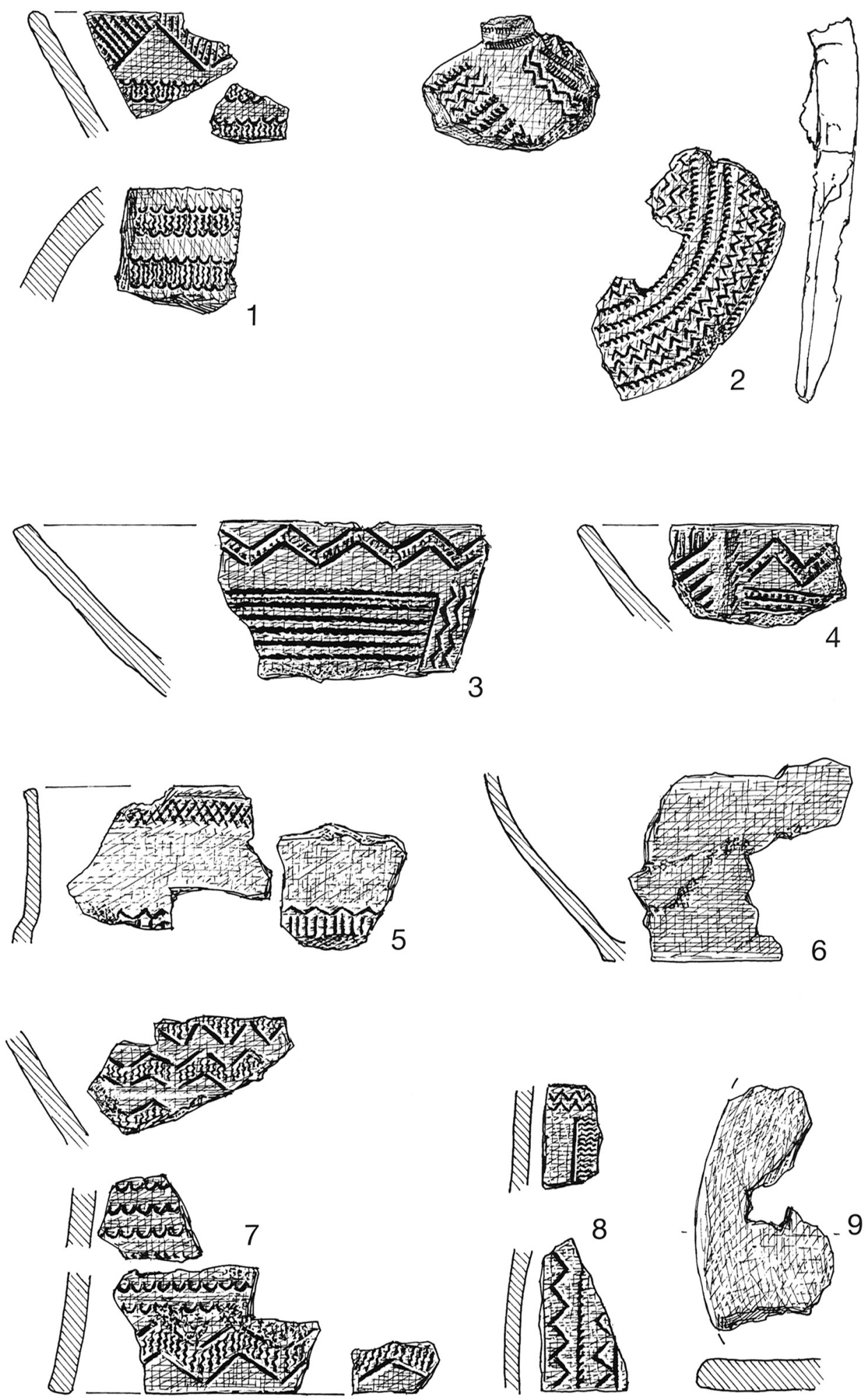


\section{Offerkarrenes placering}

Det fremgår af denne gennemgang, at skårene fra de forskellige lerkar findes ind mellem hinanden, men sådan, at skårene fra det enkelte kar sædvanligvis ligger indenfor et begrænset område. Det er derfor muligt at bestemme deponeringseller standpladsen for et ganske stort antal lerkar. Der er en svag tendens til, at de fă skulderkar er placeret tæet ved indgangen, men ellers har de forskellige lerkartyper ikke særlige pladser.

Hovedparten af keramikken fremkom sydvest og vest for gangmundingen $\mathrm{i}$ navnlig én stor koncentration. Alle lerkarformer og alle keramikstile er repræsenteret i dette område, men antallet af tragtbægre er påfaldende lille. Omvendt er antallet af fodskåle meget stort.

I hvert fald ét skulderkar fra MN II har været placeret lige foran indgangen, mens mindst 12 forskellige lerkar har været placeret øst for indgangen; på begge sider af randstenene og ovenpå disse.

Øst for gangmundingen er fundet 5 fodskåle, hvoraf de 4 er dateret til MN Ib; 1 lerske, dateret til MN Ib (og stilistisk meget lig en fodskål vest for indgangen ); 2 Troldebjergskåle, begge dateret til MN Ib; 1 tragtskål, dateret til MN II; 1 tragtbæger og 1 skulderskål, begge dateret til MN I/II samt en uornamenteret lerskive. Keramikken, som fremkom øst for gangmundingen svarer således både kronologisk og i formfordeling til offerlaget generelt. Påfaldende er også her det enlige tragtbæger og det store antal fodskåle.

Halvdelen af keramikken kan dateres til MN Ib og forekommer i alle dele af offerlaget. Denne gruppe omfatter ialt 25 lerkar, nemlig 14 fodskåle; 3 lerskeer; 1 skulderskål; 4 Troldebjergskåle; 1 tragtbæger; 1 øskenbæger og 1 tragtskål.

Kun 6 kar kan dateres til MN II. Det drejer sig om 1 Troldebjergskål (fig. 26,3), 1 skulderskål (fig. 37,9), 2 tragtskåle (fig. 26,4 og 27,3 ), 1 tragtbæger (fig. 30,2 ) og 1 ubestemmeligt lerkar (fig. 31,2). De tre af karrene er ornamenteret i tidlig Ferslevstil.

Fragmenterne af den ene tragtskål er fundet øst for gangmundingen både foran og bagved randstenene. Den har sandsynligvis været hensat på 2. randsten øst for gangen. Skårene af skulderkarret er fundet tre steder lige foran gangmundingen. Den er sandsynligvis hensat her. Skårene af de øvrige MN II-kar er alle fundet vest for gangmundingen og har alle været hensat foran randstenskæden. Skårene af de enkelte kar lå forholdsvis spredt (fig. 25).

Fragmenterne af den sene keramik er således også fundet i alle dele af offerlaget. Karrene, som stilistisk viser ganske stor variationsbredde, har været hensat både foran og på begge sider af gangmundingen såvel som på og foran randstenene. Der er således ikke tale om én, samlet hensættelse af 6 lerkar, men om mindst tre, og sandsynligvis flere, enkelthensættelser. Det svarer ganske til analyseresultaterne af MN II-keramikken foran stordyssen i Vedsted (4).

Fig. 34. Tragtskål (1), Troldebjergskål (3), tragtbæger (5), fodskål (6), skulderkar (7), bæger med konkav hals (8) og ubestemmelige lerkarfragmenter $(2 \circ \mathrm{og} 4)$. 2:5.

Funnel bowl (1), Troldebjerg bowl (3), funnel beaker (5), pedestal bowl (6), shouldered vessel (7), beaker with concave neck $(8)$, and indeterminate pottery $(2,4) .2: 5$. 

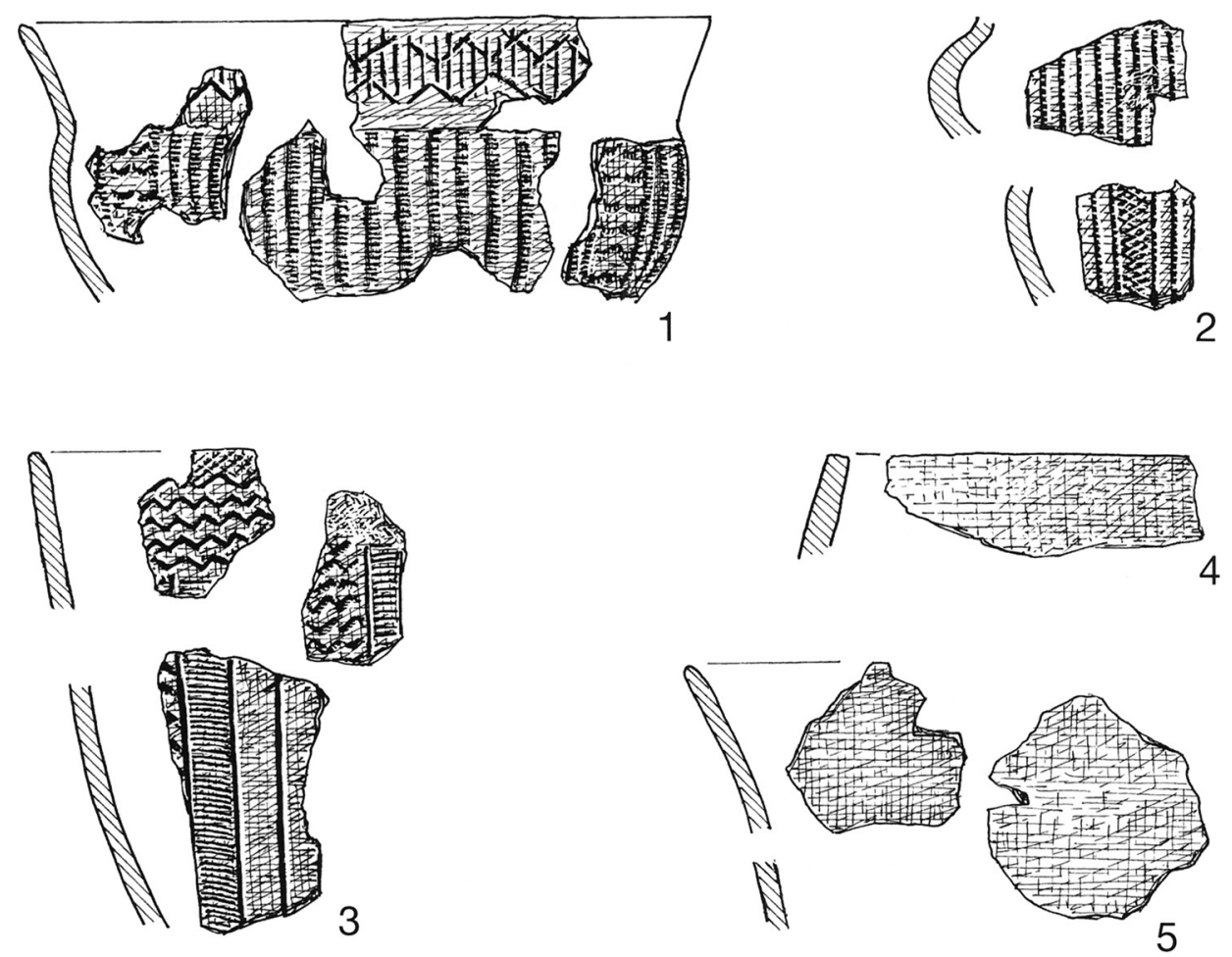

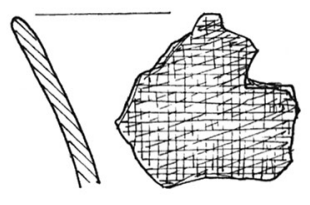

$\mathbb{A}$
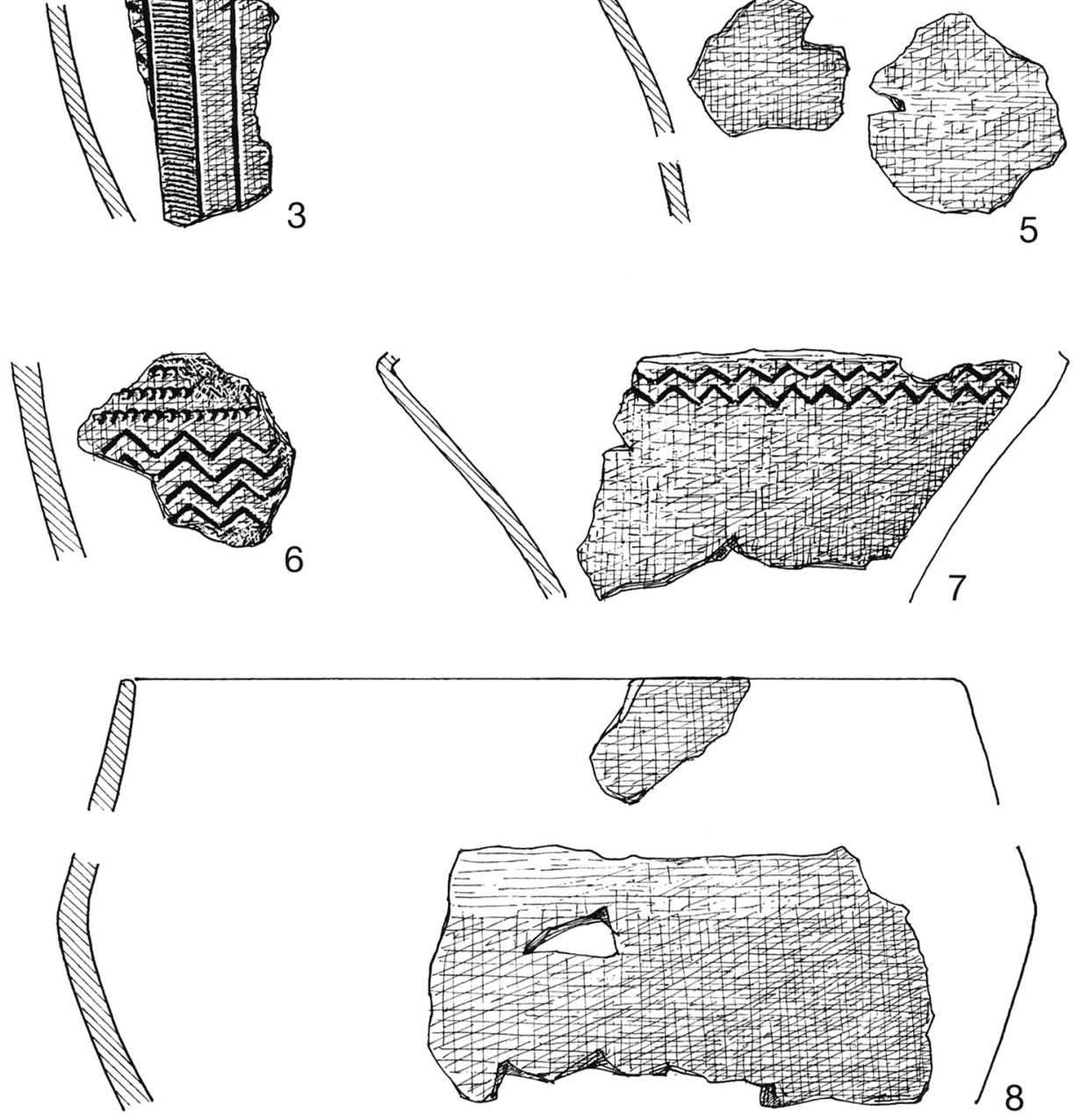


\section{Konklusion}

Jættestuens arkitektur og konstruktion er almindelig for de danske jættestuer (5). De små, ovale jættestuekamre er ligeledes særligt almindelige i Jylland. I den sydlige del af den jyske halvø er det endvidere hyppigt, at kamrene er gravet ned $\mathrm{i}$ undergrunden, og at gangen skråner ned til disse (6). Jættestuen er således bygget $\mathrm{i}$ overensstemmelse med de gængse regler. Det er heller ikke ualmindeligt, som her, at finde anlæggets oprindelige dørsten i randstenskæden henslængt ved siden af højen. Det sekundære lukke med en stendynge i og foran gangmundingen er særligt almindeligt i senneolitisk tid (6), men skal sandsynligvis her dateres til MN V.

Som tilfældet er for alle andre danske jættestuer, er også Fjerstedjættestuen opført i Klintebakkestilens tid (MN Ib). Den er bygget både som gravsted og som kultplads, men antallet af dokumenterede gravlæggelser er meget lille.

Ligeledes er offerlaget med dets kun 51 lerkar beskedent i sammenligning med andre, syd- og sønderjyske offerlag (7). Keramikkens datering til hovedsagelig MN Ib med et lille indslag af MN II-keramik svarer derimod til det almindelige i Syd- og Sønderjylland (7). Blandt lerkarrene har A.B. Gebauer tidligere diskuteret den ejendommelige fodskål (fig. 27,1) med en ekstremt lav fod (8). Ligeledes er det nære slægtskab mellem fodskålen fig. 32 og keramikken i offerlagene ved Over Jersdal, Vedsted sogn tidligere blevet påvist (9). I luftlinie er der kun ca. $25 \mathrm{~km}$ fra Fjerstedjættestuen østpå til jættestuerne i Vedsted, men denne forbindelse på tværs af halvøen er bemærkelsesværdig.

Kun sjældent kan det sandsynligggøres, at en fodskål og en lerske i et offerlag er produceret af samme pottekone, som det muligvis er tilfældet med skeen fig. 26,2 og fodskålen (fig. 32) (cf. ovenfor s. 58). De er dog fundet på hver sin side af indgangen og således ikke hensat samtidig ved siden af hinanden. Som nævint ovenfor er reparationen af cylinderhalsbægret fig. 35,2 unik i neolitisk tid.

Keramikkens formfordeling er påfaldende. Tragtbægrene udgør kun 20\% og blot et enkelt, eller et par bægre har størrelse som almindelige drikkebægre. Ligeledes er antallet af skulderskåle lille. Omvendt er i offerlaget fundet påfaldende mange fodskåle. Med 15 sikre stykker udgør de hele 34\%; den største procentvise andel i Nordeuropa.

Der er for nyligt argumenteret for, at keramikken i offerlagene stammer fra en lang række, ofte indbyrdes forskellige kultiske handlinger, alle dog med tilknytning til anedyrkelsen (10). Det er ligeledes antydet, at et par skårkoncentrationer af tragtbægre ved langdysserne i Frellesvig, Langeland, og Onsved Mark, Hornsherred, muligvis stammer fra store indvielsesfester (11). Spor efter en sådan indvielsesfest mangler ved Fjerstedjættestuen, hvor drikkebægre næsten ikke er fundet. Derimod dominerer fodskålene, der sammen med lerskeerne må opfattes som en slags rituel keramik med særlig tilknytning til gravkulten (10). Fundforholdene viser, at fodskålene og lerskeerne fra tid til anden er hensat på forskellige steder på og ved jættestuens indgangsparti. Det samme gælder for de fleste andre lerkar.

Skårlagene ved jættestuens indgang må således opfattes som resultat af gentagne, rituelle hensættelser af ét eller flere lerkar. Mange af lerkarrene er uden praktisk funktion og er sandsynligvis produceret alene med rituelt formål. 


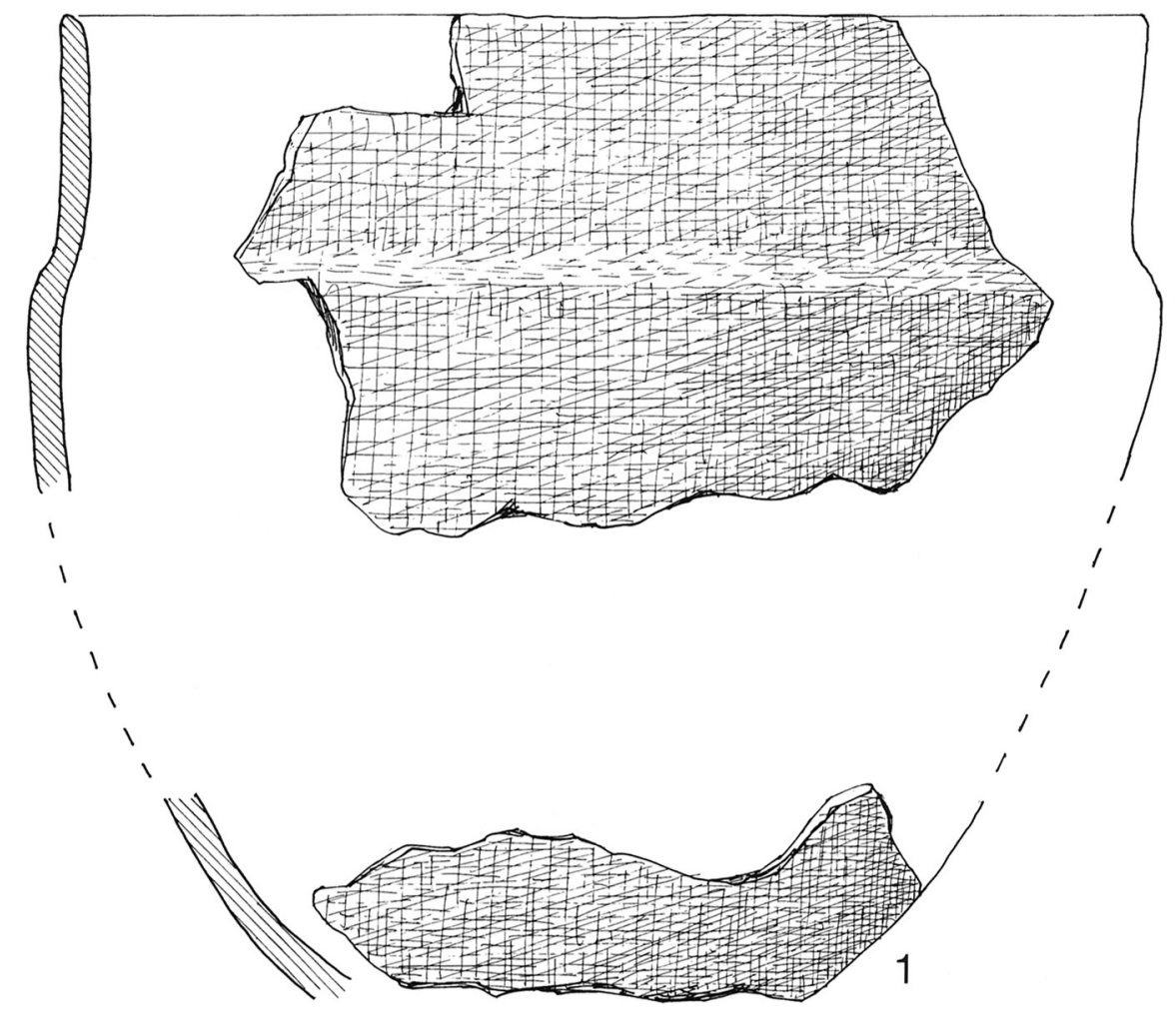

र园田

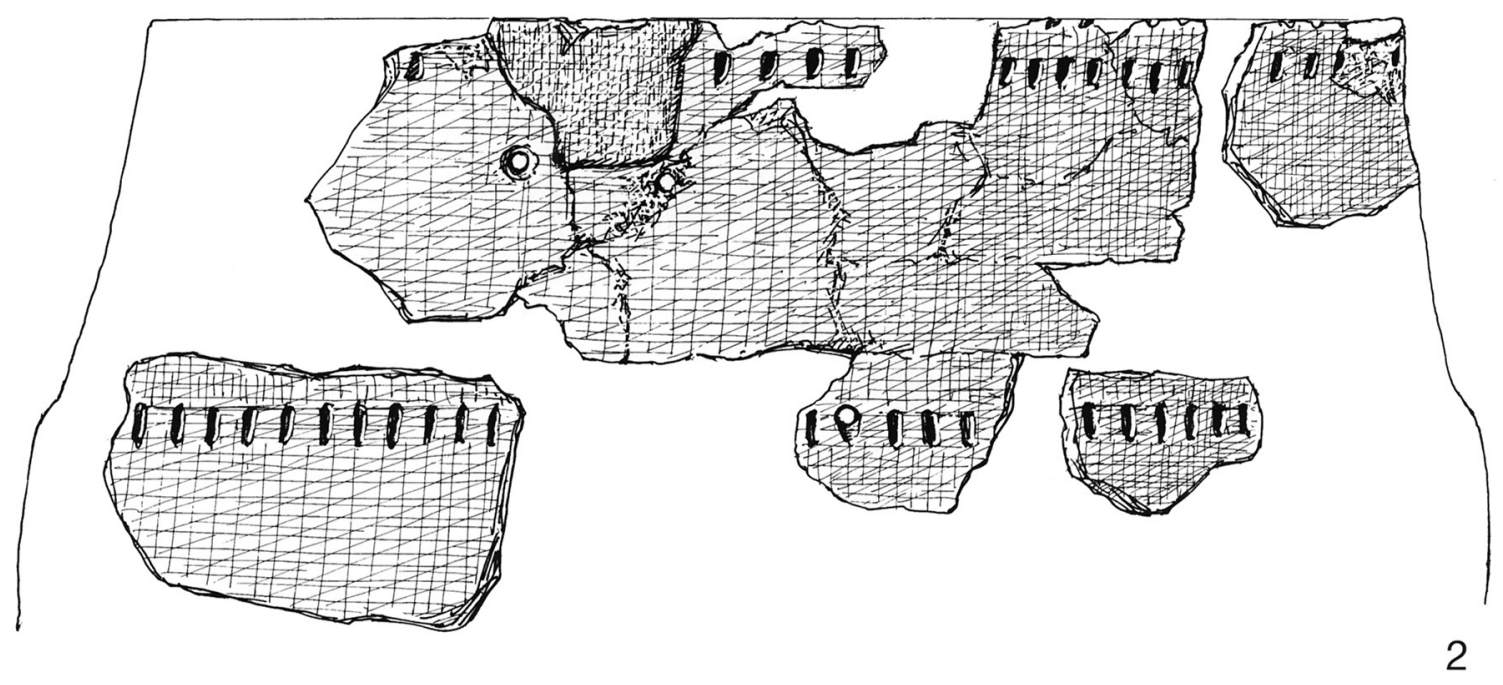

Fig. 35. Bæger med konkav hals (1) og cylinderhalsbæger (2). 2:5.

Beaker with concave neck (1) and cylinder neck beaker (2). 2:5. 

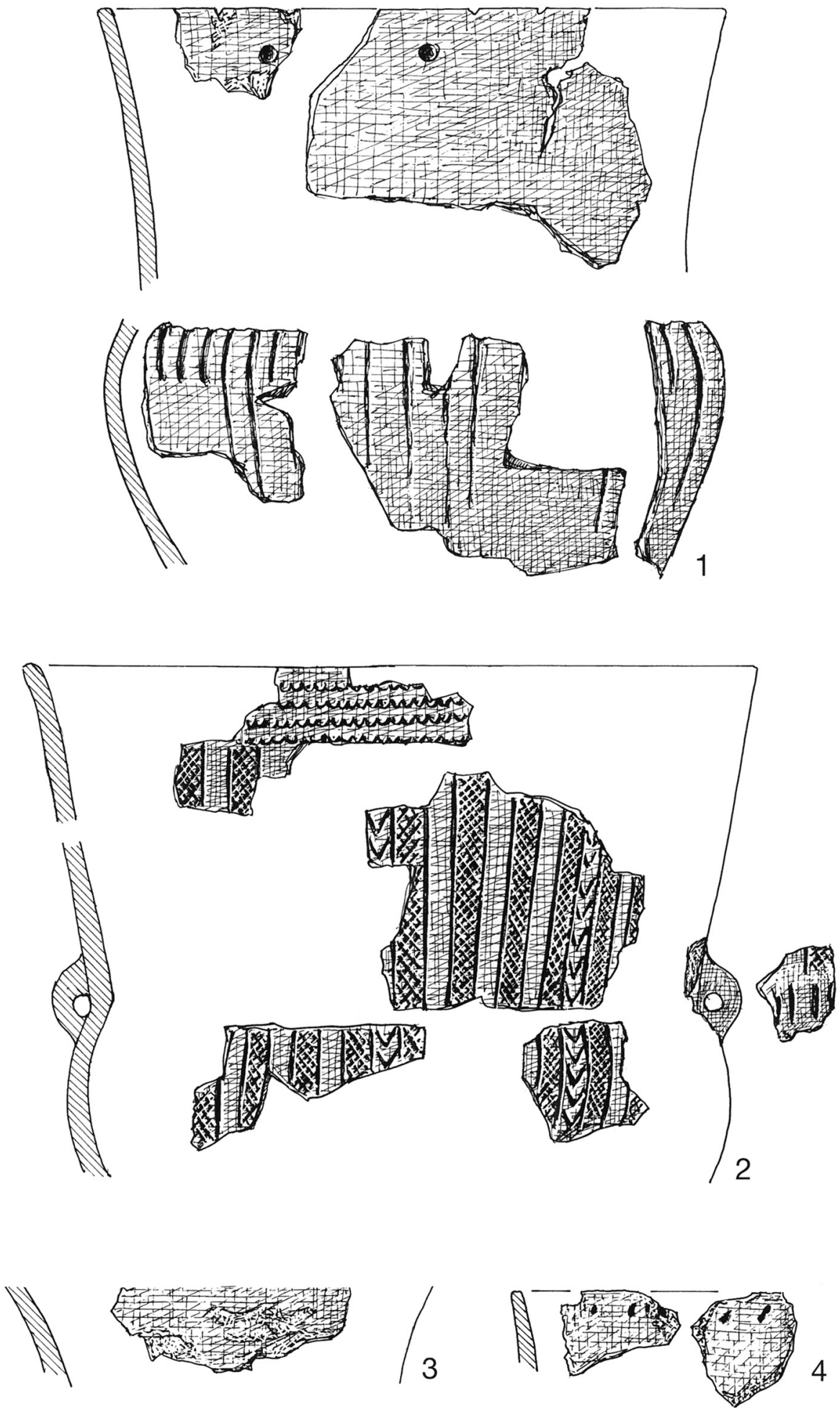


\section{Videre perspektiv}

Jættestuen ved Fjersted ligger forholdsvis isoleret (12). Således er der ca. 4 km mod sydøst til den nærmeste megalitgrav på Spandet Østermark. Det er en langdysse, som er ca. $80 \mathrm{~m}$ lang, $8 \mathrm{~m}$ bred og godt $1 \mathrm{~m}$ høj. Der er iagttaget plyndringshuller efter kamre, og på bunden af det ene er fundet en del brændt flint (13).

På Højrup Præstegård Hede, ca. $10 \mathrm{~km}$ mod VSV, er registeret en langdysse. Den er godt $30 \mathrm{~m}$ lang, men meget ødelagt. Af kammeret er registreret to stående, samt en væltet sten; i kammeret er fundet en brugt, sleben svær tyndnakket retøkse af flint (type IV-VI) (14).

$\leftarrow$ Fig. 36. Tragtbægre (1 og 3-4) og øskenbæger (2). 2:5.

Funnel beakers (1, 3-4) and lugged beaker (2). 2:5.

Fig. 37. Fodskåle (1-2), tragtbæger (3), lerskive (5), Troldebjergskåle (7 og 10), sfærisk skål (8), skulderkar (9) og ubestemmelige lerkarskår (4 og 6). 2:5.

Pedestal bowls (1-2), funnel beaker (3), clay disc (5), Troldebjerg bowls (7, 10), spherical bowl (8), shouldered vessel $(9)$, and indeterminate pottery $(4,6) .2: 5$.
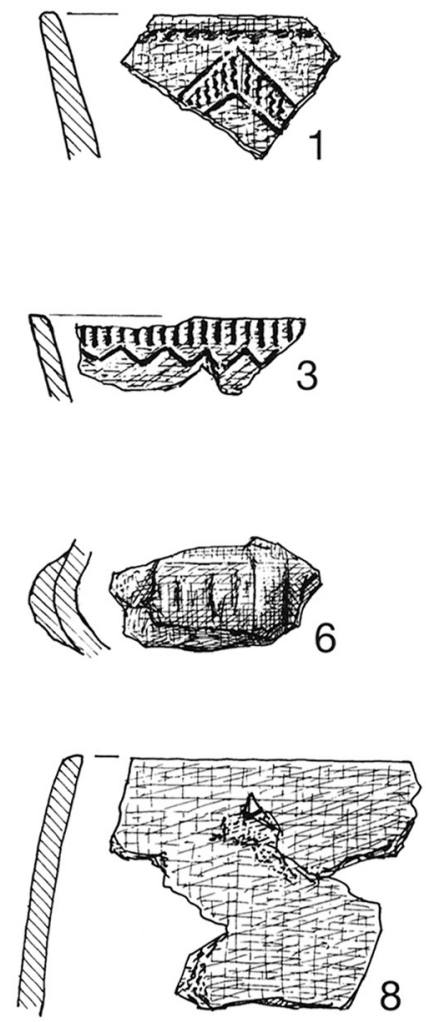
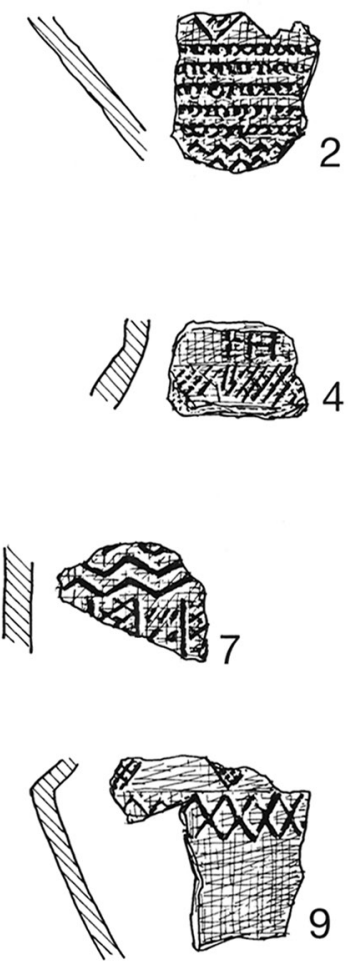
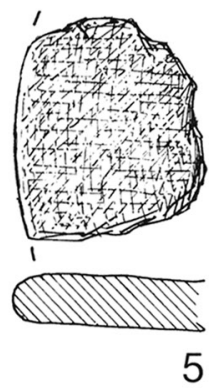

5
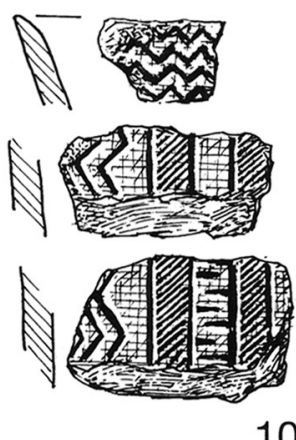

10 
I Lindet Skov, godt $10 \mathrm{~km}$ mod sydvest, er påvist en gruppe på 4 megalitgrave, nemlig to ødelagte langdysser, en runddysse og en jættestue, kaldet »Røverstuen« (15). Højen til "Røverstuen« er rund, ca. $10 \mathrm{~m}$ i diameter og 1,25 m høj. I et hul ses resterne af et kammer, som er orienteret NNØ-SSV. Det er 3,5 m langt og 2,8 m bredt. Den nordlige dæksten findes stadig, mens den anden er fjernet og brugt til et mindesmærke over kejser Vilhelm I i Løgumkloster. Der kan ligeledes ses 2 hjørnesten af kammeret og en 0,5 m bred gangåbning. Gangen er orienteret $\varnothing \mathrm{S} \varnothing-\mathrm{VNV}$, og en af dens dæksten er bevaret.

På Gånsager ved Vodder, ca. $7 \mathrm{~km}$ mod syd, er registreret et nu ødelagt dyssekammer. Der sås to stående bæresten og en afvæltet dæksten (16).

På Stavnagergård i Seem sogn, ca. 7 km mod nordvest, er undersøgt en højtomt. Den var ca. 0,5 $\mathrm{m}$ høj og indeholdt en del spredte sten, bl.a. 3 større sten, som sandsynligvis stammer fra en ødelagt megalitgrav. I højtomten er fundet fragmentet af et hængekar(?), ornamenteret i Ferslevstil; 1 tyndbladet, tyknakket flintøkse med lige æg, en buttet retmejsel, sekundært tildannet af et ægfragment samt 1 flække (17).

Ca. $6 \mathrm{~km}$ mod nordøst ved Enderup Skov i Gram sogn er registreret 2 sløjfede megalitgrave. Det ene anlæg er dokumenteret af lidt brændt flint på et sted, hvor der skal have været en høj med et gravkammer (18). Det andet anlæg er en langdysse, som skal have indeholdt 4 kamre. I de to skal være fundet ravperler, i de to andre en mængde lerkarskår. Et af dyssekamrene er undersøgt af H. Lund, Haderslev Museum, som fandt et uornamenteret randskår og ægfragmentet af en flintøkse. Dyssekammeret var bygget af 4 bæresten, der omsluttede et rektangulært kammer, ca. 1,5 m langt og 0,8 m bredt. Det havde tærskelsten mod nord og var dækket af én tærskelsten. Fra anlægget stammer sandsynligvis også et fund af 2 fragmenterede fodskåle, 1 Troldebjergskål og 1 skulderkar, alle ornamenteret i Klintebakkestil (19).

Noget længere nordpå ved Gram Å er endelig registreret endnu en langdysse. Den var orienteret NØ-SV; ca. $26 \mathrm{~m}$ lang, $11 \mathrm{~m}$ bred og 1,2-1,5 m høj. 12 $\mathrm{m}$ fra den sydvestlige ende er iagttaget et plyndringshul, hvori sås rester af et sprængt kammer. Der er tillige set én randsten (20).

Det fremgår af denne oversigt, at antallet af megalitgrave i omegnen af Fjersted er meget begrænset. Det svarer helt til, hvad der generelt er tilfældet i den vestlige dele af den jyske halvø (21).

Anlægget ved Fjersted er endvidere en af de få jættestuer, og et af de fă keramik-offerlag, som i det hele taget er påtruffet i SV-Jylland og Vestslesvig.

Den nærmeste jættestue er den ovenfor nævnte "Røverstuen« i Lindet Skov, som findes $10 \mathrm{~m}$ mod sydøst.

Mod nord ved Veldbæk i Esbjerg er undersøgt langdyssen "Skibhøj« (22), en langhøj dannet ved en ombygning af to rundhøje. Der registreredes en ødelagt megalitgrav i begge høje. Ved den østlige rundhøj fandtes dele af en randstenskæde og et indgangsparti, samt en stenlægning foran denne. Under stenlægningen fremkom et meget stort offerlag, omfattende ca. 120 lerkar. Offerlaget består af mange Troldebjergskåle, fodskåle, tragtbægre og skulderkar, samt en del lerskeer, lerskiver, tragtskåle, bægre og skåle med konkav hals, åbne skåle, cylinderhalsbægre og hængekar. Hovedparten af keramikken kan dateres til $\mathrm{MN} \mathrm{Ib}$, men enkelte kar er senere. 
Ligeledes i Veldbæk, men lidt derfra, er i 1960-erne ved Veldbæk Skole undersøgt tomten af en langhøj, ved hvis sydside fremkom et stort offerlag (23). Keramikken kan udelukkende dateres til MN I(b). Den omfatter tragtbægre, fodskåle, skulderskåle og -kopper, Troldebjergskåle, åbne skåle, lerskiver og lerskeer.

Længere mod øst findes i Grimstrup krat ved Roust tomten af en jættestue (24). Ved højens sydside er undersøgt et stort offerlag, omfattende tragtbægre, fodskåle, lerskeer, Troldebjergskåle, skulderskåle og -kopper, lerskiver, m.v. Keramikken er overvejende dateret til MN Ib.

Ved Borre, Ål sogn, er undersøgt en høj med et Ø-V-orienteret stordyssekammer (25). Ved indgangen undersøgtes et meget stort offerlag, omfattende mindst 100 forskellige lerkar, hovedsagelig dateret til MN Ib. Mindst én fodskål er ornamenteret i Troldebjergstil, mens et par lerkar kan datereres til MN II og III. Keramikken omfatter fodskåle, lerskeer, Troldebjergskåle, tragtbægre, skulderskåle og -kopper, lerskiver, øskenbægre, åbne skåle, og én sfærisk skål.

I det gamle Ribe amt er herudover kun registreret yderligere to sikre jættestuer, nemlig den kendte jattestue i Mejls ved Varde med et forholdsvis lille offerlag (26), samt en jættestue ved Nyby i Læborg sogn (27-28).

Mod syd er i Steneng ved Bredebro (29) undersøgt to parallelle langdysser, den østlige med ét gravkammer, den vestlige med tre gravkamre. Mellem dysserne undersøgtes et stort offerlag omfattende tragtbægre, Troldebjergskåle, fodskåle, lerskeer, skulderkar, samt enkelte tragtskåle, lerskiver og åbne skåle med konvekse sider. I fundet indgår også en tragtskål, ornamenteret i Lindøstil og et bæger fra MN V. En enkelt fodskål fra offerlaget er ornamenteret i Troldebjergstil; en åben skål med konvekse sider er ornamenteret i Blandebjergstil, mens den øvrige keramik i offerlaget kan dateres til MN Ib.

Sydøstpå ved Bov i Burkal sogn er i 1927 undersøgt tomten af en megalitgrav. Ved højens sydside fremkom et stort offerlag, omfattende tragtbægre, fodskåle, lerskeer, Troldebjergskåle, skulderkar, tragtskåle samt enkelte bægre med konkav hals, åbne skåle og lerskiver. Hovedparten af keramikken kan dateres til $\mathrm{MN} \mathrm{Ib}$, men i fundet indgår flere lerkar, ornamenteret i Ferslevstil og enkelte i Valby-stil (30).

Ude ved Møgeltønder er endvidere registreret en jættestuelignende stensætning af store sten, med en gang mod sydvest. Den skal have haft brolagt bund, hvorpå er fundet en perle (31).

Syd for grænsen skal man på fastlandet helt til Schwesing ved Husum for at finde de nærmeste jættestuer (32). I Schwesing (Grabhügel 4-8) er undersøgt ialt 5 ødelagte megalitgrave, hvoraf de to sandsynligvis er jættestuer i rundhøje; én langhøj, muligvis også med en jættestue samt to andre høje, der er så ødelagte, at de kun tillader en formodning om anlæggenes form. Beklageligvis er fundene fra de enkelte dele af anlæggene ikke holdt adskildt. De fleste af fundene stammer dog fra offerlagene. Ved høj 4 er således undersøgt et offerlag fra $\mathrm{Ib}$ (II) omfattende af fodskåle, lerskeer, tragtbægre og skulderkar. Offerlaget ved høj 5 omfatter fodskåle, Troldebjergskåle og tragtbægre. Det kan ligeledes dateres til $\mathrm{MN} \mathrm{Ib}(-\mathrm{II})$. Fundene fra høj 6 omfatter et rigtornamenteret øskenbæger, Troldebergskåle, tragtbægre, skulderkar, samt en åben uornamenteret miniatureskål. De kan dateres til MN Ib(-II). Fundene fra høj 7 omfatter en uornamen- 
teret lerskive, et øskenbægre, et tragtbæger og en skulderskål, mens fundene fra høj 8 omfatter tragtbægre, skulderskåle og en fodskål.

Noget derfra i Schwesing er undersøgt tomten af yderligere en jættestue. På kammerbunden fandtes en yngreneolitisk retøkse af flint, 5 lerkar (bl. a. tragtskåle og et hankekar) fra slutningen af mellemneolitisk tid samt 4 flækker (33). Længere mod syd er midtvejs mellem Schwesing og Rantrum undersøgt tomten af en jættestue (34), mens der i Schwabstedt ved Ejderen er undersøgt tomten af en jættestue med et stort offerlag, der omfattede fodskåle, lerskeer, skulderkar, tragtbægre, Troldebjergskåle, øskenbæger samt ubestemmelige lerkar (35).

I den øvrige del af det nordfrisiske fastland er ikke registreret sikre jættestuer (36). Derimod er der påfaldende mange jættestuer på øen Sild. Der gælder først og fremmest de berømte jættestuer "Denghoog" og "Strumphoog« 1 Wenningstedt, i hvis kamre der er fundet mange gravgaver fra hele mellem (og yngreneolitisk) tid (37). Dernæst jættestuen »Tjülsekerhoog« i Archsum, hvor der er fremkommet et stort offerlag med keramik, ornamenteret i MN Ib-stil (38). Ved Archsum er yderligere registreret 3 jættestuer (39). I det nærliggende Keitum er undersøgt ét stort offerlag (40). Hertil kommer yderligere mindst 5 jæettestuer i Kampen (41). Indenfor to ganske små geografiske områder på Sild er således dokumenteret mindst 12 jættestuer/offerlag (42). Hertil skal så føjes mindst 28 tomter og andre megalitanlæg, som yderligere er registreret på Sild.

På Föhr er registreret ialt 15 megalitgrave, heriblandt tre jættestuer ved henholdsvis Nieblum, Utersum og Süderende. I alle er fundet gravgaver fra mellemneolitisk tid. (43).

På Amrum er registreret ialt 13 megalitgrave, deriblandt en langdysse med to stordysser samt en ubestemmelig gravhøj med én stordysse. I begge er fundet gravgaver fra mellemneolitisk tid (44).

Betragtes Sydvestjylland og Vestslesvig under ét, tegner sig således et interessant billede. Antallet af jættestuer og tidlige, mellemneolitiske offerlag er generelt beskedent, og sædvanligvis er der ganske langt mellem de enkelte pladser. På Sild derimod findes en meget stor koncentration af jættestuer, hvis betydning hidtil har været overset i dansk arkæologi (45). I luftlinie er der kun ca. $40 \mathrm{~km}$ fra Fjerstedjættestuen til denne koncentration. Næsten $40 \%$ af alle jættestuer/offerlag i Sydvestjylland-Vestslesvig findes her på Silds moræneknolde. Også ved Schwesing og i Esbjerg er fundet mindre koncentrationer af jættestuer og/eller offerlag.

Da ødelæggelsesgraden for megalitgrave generelt er lille i det vestlige Jylland og iøvrigt nogenlunde proportional med det oprindelige antal, er dette billede utvivlsomt et ægte udtryk for den geografiske variation i jættestuernes antal (46).

Man må derfor regne med, at der generelt i Sydvestjylland og Vestslesvig i begyndelsen af mellemneolitisk tid (næsten udelukkende $\mathrm{MN} \mathrm{Ib)} \mathrm{er} \mathrm{bygget} \mathrm{for-}$ holdsvis fă jættestuer/stordysser, og at der generelt har været betydelig større afstand mellem de enkelte anlæg her end i det øvrige, danske område. Specielt på Sild, men også enkelte andre steder, har man derimod opført jættestuer i et stort antal indenfor et forholdsvis lille område. 
Dette afspejler sandsynligvis også befolknings- og bebyggelsesintensiteten omkring år 3200 f.v.t. (MN Ib) (47). Generelt var der større afstand mellem de små, bebyggede områder i Vestjylland og Vestslesvig end længere østpå i Danmark og Nordtyskland. I den forholdsvis svagt bebyggede, vestlige del af den jyske halvø kan der dog også findes strøg med en tættere bebyggelsesintensitet og sandsynligvis samtidig flere mennesker.

Selve bosættelsens overordnede struktur er således ens i hele Sydskandinavien/Nordtyskland. Det samme galder for karakteren af offerhandlingerne ved jættestuerne/stordysserne, selvom der naturligvis kan være individuelle forskelle på hændelsesforløbet det enkelte sted. I keramikken kan endvidere ses klare stilistiske fællestræk mellem Øst- og Vestjylland. Vi må derfor regne med, at samfundets struktur og organisationsform har været den samme i Sydvestjylland/Vestslesvig som i det øvrige Sydskandinavien/Nordtyskland. 


\section{Katalog}

\section{A. Fund fra kammeret}

1. Fragm. og forv. symm. dobbeltøkseformet ravperle med halvcirkelformede ægblade og rektangulære indskæringer ved gennemboringen. $2,0 \mathrm{~cm} \mathrm{l,} 1,5 \mathrm{~m} \mathrm{~cm} \mathrm{h,} 0,5 \mathrm{~cm}$ t. gb. $0,3 \mathrm{~cm}$. MN I-V. Fig. 16,3.

2. Fragm. og forv. symm. spoleformet ravperle med smalt mellemstykke og halvkugleformede

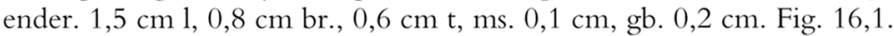

3. Størstedelen af en tragtskål med antydning af en skulder på den nederste del af halsen. Her ses et vandret felt af lodretstreger, indstemplet med et uregelmæssigt, dråbeformet stempel. Under randen er karret ornamenteret med en indstemplet dobbeltvinkellinie, mens der på den øverste del af bugen findes en, ligeledes indstemplet vinkellinie. Md. $18 \mathrm{~cm}$. Ca. $11 \mathrm{~cm} \mathrm{h.} \mathrm{MN} \mathrm{II.} \mathrm{Fig.}$ 16,6 .

4. Størstedelen af et tøndeformet lerkar, med meget skarpt afsat fod. Lige over største bredde ses en flygtig udført, vandret række grove, skrå indstik. Spor af et øsken/en knop(?) ses. Bd. 7,4 cm. $>16 \mathrm{~cm}$ høj. MN V. Fig. 16,8.

5. Skårflage af en uornamenteret, sfærisk miniatureskål med rund bund. Den er lavet af groftblandet gods. Md. $12 \mathrm{~cm}$. Ca. $9 \mathrm{~cm}$ høj. Udateret. Fig. 16,7

6. Uornamenterede lerkarskår.

\section{$B$. Fund fra offerlaget}

Flint og rav

1. En tværpil, tildannet af et skiveformet afslag med en bagfra lavet retouche på de lange kanter. $2,5 \mathrm{~cm} \mathrm{l,} \mathrm{1,6} \mathrm{cm} \mathrm{br.} \mathrm{Fig.} \mathrm{16,5.}$

2. Fragm. og forv. symm. spoleformet ravperle med langt, dybt indskåret mellemstykke. $1,9 \mathrm{~cm} \mathrm{l,}$ ms. 0,9 cm. Fig. 16,2.

3. Forvitret rørformet ravperle med brugsspor. $0,5 \mathrm{~cm} \mathrm{l,} 0,6 \mathrm{~cm}$ i diam. Gb. $0,2 \mathrm{~cm}$. Fig. 16,4.

Fodskåle.

3. Fragm. af fodskål med ekstremt lav fod. Foden er kun ca. $3 \mathrm{~cm}$ høj. Den er ornamenteret med en vandret, indridset dobbeltvinkellinie. Skålen er under randen ornamenteret med vandrette, indridsede vinkellinier, derunder af vandrette kommastiklinier, som danner en meget dyb fure. Ét sted på den nederste del af skålen ses en bred og flad fortykkelse som imiterer en hank. Den er ornamenteret med lodrette linier i falsk beviklet snor. Modsat hankimitationen ses et lodret mønster af vandrette vinkelbånd; afvekslende glatte og udfyldt med krydsskravering. MN I-II. Fig. 27,1.

4. Fragm. af en fodskål. Under randen er skålen ornamenteret med en indstemplet vinkellinie og et krydsskraveret felt. Derunder ses et fladedækkende mønster af vandrette linier i halvbuestik; sandsynligvis ved hankene afbrudt af lodrette felter med vandrette vinkler udfyldt med skrå tandstokindtryk. Ved fodkanten ses et vandret indstemplet vinkelbånd, udfyldt med lodrette cardiumindtryk. Derover findes på foden vandrette rækker af store, grove halvbuestik.

Md. ca. $26 \mathrm{~cm}$. MN Ib. Fig. 33,7.

5. Størstedelen af en fodskål. Under randen ses en vandret række hængende, skråskraverede trekanter, udført i beviklet snor. Derunder findes på skålen et fladedækkende mønster af vandrette halvbuestiklinier. De afbrydes af lodrette dobbeltvinkelrækker i beviklet snor. Nedadtil afsluttes skålens ornamentik af en vandret række hængende trekanter. Indramningen er udført i beviklet snor og skråstregerne er indridsede. På foden ses samme mønster som på skålen, blot med nedadrettede halvbuer og med en vandret række stående trekanter øverst. Ved fodkanten findes 3 vandrette linier i beviklet snor. Md. $36 \mathrm{~cm}$. Fd. ca. $20 \mathrm{~cm}$. MN Ib. Fig. 27,2

6. Størstedelen af en fodskål. Under randen og ved fodkanten ses 3 vandrette vinkellinier i beviklet snor. Derunder og -over er skål og fod ornamenteret med vandrette rækker af kommastiklinier. Denne ornamentik afbrydes ved hankene. På foden ses ved hankene et felt af vandrette, indstemplede vinkellinier, omgivet af lodrette linier i beviklet snor, nogle steder tillige i kombination med lodrette, plastiske lister. På skålen findes ved hankene et tilsvarende mønster, blot bestående af lodrette vinkellinier. Hankene er ornamenteret med vandrettte linier, indrammet af lodrette linier i beviklet snor. Md. ca. 40 cm. Fd. ca. 24 cm. MN Ib. Fig. 32 . 
7. Dele af fodskål. Under randen ses et groft indridset, vandret vinkelbånd med krydsskravering. Derunder er karret på skålen ornamenteret med vandrette, indridsede linier. Et sted afbrydes ornamentikken af lodrette, indstemplede vinkellinier. Md. $32 \mathrm{~cm}$. MN Ib. Fig. 33,3.

8. Randskår af en fodskål. Lerkarret er under randen ornamenteret med et groft indridset vinkelbånd med skrå linieudfyldning. Derunder findes vandrette liniebånd, også disse udfyldt med skrå indstik. Et sted afbrydes ornamentikken af en hængende trekant. Derunder ses spor af grov, lodret vinkelrække. MN Ib. Fig. 33,4.

9. Fragm. af fodskål. Under randen og ved overgangen til foden ses vandrette rækker af indridsede, hængende trekanter med skråstreger. Derunder findes på skålen et fladedækkende mønster af vandrette linier $\mathrm{i}$ halvbuestik med åbningerne opad. På et kantskår af foden ses vandrette halvbuestiklinier med åbningerne nedad. Hanken er ornamenteret med lodrette linier i halvbuestik. Md. ca. 38. MN Ib. Fig. 31,5.

10. Fragm. af fodskål. Under randen og ved fodkanten er den ornamenteret af vandrette, indridsede dobbeltvinkellinier som udsparer glatte rhomber. Ved hankene forsætter dette mønster ned $i$ et lodret felt af vandrette vinkellinier. På den øverste del af foden og nederste del af skålen ses indridsede vinkellinier. Fodskålen er i øvrigt ornamenteret med vandrette linier af halvbuestik. MN Ib. Fig. 31,9.

11. Fragm. af fodskål. Under randen og nederst på skålen ses en vandret række hængende trekanter, omgivet af en indstemplet vinkellinie, og udfyldt med lodrette, indstemplede streger. Derimellem ses et fladedækkende mønster af vandrette kommastiklinier; sandsynligvis ved hankene afbrudt af felter med vandrette vinkellinier. Et sted på skålen ses lodrette vinkelbånd, udfyldt med krydsskravering. På foden ses ligeledes vandrette kommastiklinier, men her ved hankene afbrudt af blanke felter. Hankene er ornamenteret med vandrette, indstemplede vinkelbånd med krydsskravering. Md. ca. $34 \mathrm{~cm}$. MN Ib. Fig. 28.

12. Fragm. af fodskål. Under kanten er den ornamenteret med en indridset dobbeltvinkellinie. De derved fremkomne trekanter er udfyldt med skråskravering. Derover findes på foden vandrette kommastiklinier; ved hanken? afbrudte felter med lodrette vinkelrækker. MN Ib. Fig. 31,7.

13. Skår af en fodskål. Under randen er den ornamenteret med mindst 2 indstemplede vinkellinier. Derunder ses et fladedækkende mønster af kommastiklinier, sandsynligvis afbrudt ved hanken af en anden ornamentik, indrammet af lodrette vinkelllinier. Nederst på skålen ses ligeledes spor af vinkler. MN Ib. Fig. 37,2.

14. Fragm. af en fodskål. På skålen er den ornamenteret med vandrette kommastiklinier og derunder 4-dobbelte, indstemplede vinkellinier. MN Ib. Fig. 34, 6.

15. Tre skår af en stærkt forvitret fodskål. På skålen ses under randen en vandret linie med uregelmæssige indstik i bunden og derunder et indstemplet vinkelbånd, udfyldt med lodrette cardiumindtryk. MN Ib. Fig. 37,1.

16. Fragm. af fodskål. Under randen ses en vandret række hængende, indridsede trekanter med skravering. Derunder findes på skålen og den ca. $5 \mathrm{~cm}$ brede, båndformede hank vandrette liniebånd, indrammet af store halvbuelinier og udfyldt med lodrette cardiumindtryk. Et skår, hvorpå ses indstemplede vinkelbånd, udfyldt med lodrette cardiumindtryk, hører sandsynligvis med til denne fodskål. Md. ca. $36 \mathrm{~cm}$. MN Ib. Fig. 33,1.

17. Fragm. af fodskål. Under randen og ved fodkanten ses tre vandrette, indstempelde vinkellinier. På foden ses et fladedækkende mønster af vandrette linier i beviklet snor. Det afbrydes af et mønster beståede af lodrette 3-dobbelte linier, som indrammer et felt af lodrette vinkelrækker. På hankene ses vandrette linier, indrammet af lodrette linier, også disse i beviklet snor. MN Ib. Fig. 31,8 .

\section{Lerskeer}

18. Størstedelen af en lerske med rundt blad og fremstående dølle. Den har glat, hvælvet overflade. På døllen er den ornamenteret med vinkelstillede liniestykker i beviklet snor. På fladen ses et fladedækkende mønster af omløbende rækker af halvbuestik. Ved døllens forlængelse ind mod bladets midte findes et mønstrer af enkelte vinkelbånd, hvor hver anden er udfyldt med cardiumindtryk. De omgivende linier er lavet i beviklet snor. Ca. $15 \mathrm{~cm}$ i diam. Døllen er $3 \mathrm{~cm} 1 \mathrm{og} \mathrm{ca}$. $3 \mathrm{~cm}$ i diam. Hullet er ca. $0,9 \mathrm{~cm}$ i diam. MN Ib. Fig. 26,2.

19. Fragmenter af en lerske med rundt blad og fremstående, uornamenteret dølle. Ved siden af døllen er til den ene side bevaret dele af en fremstående knop. Denne er på oversiden ornamenteret med omløbende linier i beviklet snor. Spor af mindst 4 tilsvarende linier ses ved overgangen 
fra blad til dølle. På bladet er den ornamenteret med et fladedækkende mønster af omløbende linier. De består af afvekslende halvbuestik, sammensat til kommastiklinier og indstemplede, 3dobbelte vinkellinier. MN Ib. Fig. 33,2.

20. Fragment af lerske med spadeformet blad og en lille, ikke særlig fremtræedende dølle. På kanten af den yderste del af bladet ses en indstemplet vinkelrække. På bladet findes et fladedækkende mønster af omløbende rækker af tætstillede halvbuestik. Bladets centrum er glat. Yderst langs kanten findes et indstemplet vinkelbånd udfyldt med lodrette streger. MN Ib. Fig. 26,1.

\section{Troldebjergskåle}

21. Størstedelen af en Troldebjergskål. Under randen ses et vandret bånd, omgivet af vandrette rækker af halvbuestik og udfyldt med korte, skrå tandstokindtryk. På halsen findes et stort vinkelbånd i tandstok og udfyldt med lodrette tandstokindtryk. Ved overgangen fra hals til bug ses en vandret tandstoklinie. Bugen er ornamenteret med 3-dobbelte bånd; det midterste udfyldt med en fin lynlåsornamentik, de omgivende med skrå tandstokindtryk. Ornamentikken afsluttes nedadtil af 2 vandrette rækker af halvbuestik. Md. ca. $22 \mathrm{~cm}$. Bd. ca. $10 \mathrm{~cm}$. Ca. $16 \mathrm{~cm} \mathrm{h.} \mathrm{MN} \mathrm{II}$ (tidlig Ferslevstil). Fig. 26,3.

22. Fragm. af Troldebjergskål. Under randen ses et vandret, krydsskraveret felt og derunder mindst 4 vandrette, indstemplede vinkellinier. På bugen ses lodrette 3-dobbelte bånd; det midterste udfyldt med en grov lynlåsornamentik og/eller lodrette vinkelrækker, de omgivende med fint indstemplede skråstreger. Nogle steder - under øsknerne ? - findes flerdobbelte, lodrette vinkelrækker. MN Ib. Fig. 34,3.

23. Fragm. af Troldebjergskål. Under randen er den ornamenteret med indstemplede vinkellinier. På bugen ses lodrette bånd, udfyldt med vandrette cardiumindtryk. På et skår (muligvis under en øsken) ses lodrette, indstemplede vinkellinier, omgivende en groft indridset, lodret linie. MN Ib. Fig. 33,8.

24. Fragm. af Troldebjergskål. Under randen er den ornamenteret med mindst 4 vandrette, indstemplede vinkellinier. På bugen ses lodrette, tredobbelte bånd; det midterste udfyldt med lynlås, de omgivende med skråstreger i en fin tandstok. Her findes også lodrette enkeltbånd, udfyldt med fine, skrå tandstokindtryk samt lodrette, indstemplede 3-dobbelte vinkellinier. MN Ib. Fig. 37,10 .

25. To skår af Troldebjergskål. Under randen ses mindst 3-dobbelte, vandrette, indstemplede vinkellinier. På bugen ses lodrette, tredobbelte bånd; det midterste udfyldt med en lodret vinkelrække, de omgivende med krydsskravering. MN Ib. Fig. 37,7.

\section{Skulderkar}

26. Frag. af skulderkar. På skulderen ses en vandret række hængende, skråskraverede trekanter. Øverst på bugen ses to vandrette, indstemplede vinkellinier, som udsparer små, glatte rhomber mellem sig. MN II. Fig. 37,9.

27. Fragm. af en skulderskål. Under randen ses en vandret række halvbuestik og en indstemplet vinkellinie. Ved halsfoden findes en vandret linie, mens skulderen er ornamenteret med lodrette liniegrupper. Mønstrene på og ved skulderen er lavet i beviklet snor. Md. ca. $14 \mathrm{~cm} .>9 \mathrm{~cm} \mathrm{~h}$. Md. ca. $12 \mathrm{~cm}$. MN Ib. Fig. 29,1.

28. Fragm. af skulderkar. På skulderen ses hængende, udskrabede trekanter. På den øverste del af bugen er karret oramenteret med en indstemplet dobbeltvinkellinie. MN I-II. Fig. 34,7.

29. Tre halsskår af et skulderkar. Under randen og ved halsfoden ses henholdsvis to og én vandret, indstemplet vinkellinie. MN I/II. Fig. 31,1.

\section{Tragtskåle}

30. Tragtskål med stærkt udfaldende rand og glattet overflade. Under randen ses et vandret, krydsskraveret felt. På halsen findes lodrette, bredt indridsede liniegrupper. På den øverste del af bugen er karret ornamenteret med lodret afstribning, der nogle steder er afbrudt af glatte felter. Ornamentikken afsluttes nedadtil af en indstemplet dobbeltvinkellinie. Md. $26 \mathrm{~cm},>14 \mathrm{~cm} \mathrm{~h}$. MN II. Fig. 27,3.

31. Størstedelen af en tragtskål. Under randen ses en vandret linie og et krydsskraveret felt. Ved overgangen fra hals til bug ses en indstemplet vinkellinie og derunder lodret afstribning. Ornamentikken er flygtigt lavet. Md. ca. 30. MN I-II. Fig. 33,5.

32. Størstedelen af en tragtskål. På halsen ses en vandret rhomberække, udfyldt med lodrette streger. Ornamentikken er meget flygtigt udført. På en øverste del af bugen findes et mønster af lod- 
rette linier i en grov, beviklet snor, nogle steder afvekslende med lodrette rækker af halvbuestik. Md. ca. $20 \mathrm{~cm}$. MN Ib. Fig. 34,1.

33. Størstedelen af en tragtskål. Under randen ses et sammensat, vandret mønster af to indstemplede vinkellinier, to indridsede linier og en indstemplet vinkellinie. Ved hals/bugovergangen og nederst på bugen ses henh. én og to indstemplede vinkellinier. Derimellem findes på den øverste del af bugen lodrette, indridsede liniegrupper omgivet med lodrette, indstemplede dobbeltvinkellinier. Md. ca. $26 \mathrm{~cm} .>12 \mathrm{~cm}$. MN II. Fig. 26,4.

\section{Tragtbagre}

34. Størstedelen af et magnum-tragtbæger. Under randen findes to vandrette, flygtigt indridsede vinkellinier. På den øverste del af bugen ses lodrette, forholdsvis korte bugafstribninger, ligeledes flygtigt udført. Md. ca. $34 \mathrm{~cm}$, bd. ca. $10 \mathrm{~cm}$. Ca. $35 \mathrm{~cm}$ h. MN I-II. Fig. 29,3.

35. Fragmenter af et stort tragtbæger med glattet overflade. Under randen ses to vandrette rækker indstemplede, runde gruber. MN I-II. Fig. 31,4.

36. Fragm. af stort, uornamenteret tragtbæger. Md. ca. 20 cm. Udat. Fig. 36,3.

37. Fragm. af stort, uornamenteret tragtbæger med glattet overflade. Md. ca. $18 \mathrm{~cm}$. Bd. ca. 10 cm. Udat. Fig. 34,5 .

38. Fragm. af tragtbæger. Under randen er karret ornamenteret med en vandret række skrå, diffuse indstik. Md. 15-20 cm. MN I-II. Fig. 36,4.

39. Fragm. af tragtbæger med glattet overflade. Under randen ses en vandret række runde indstik. På den øverste del af bugen ses en flygtigt udført, grov, lodret afstribning, som nogle steder når helt ned til bunden. Md. ca. $25 \mathrm{~cm}$. MN I-II. Fig. 36,1.

40. Fragm. af et tragtbæger. Under randen er det ornamenteret med en vandret række lodrette streger og en vinkellinie. Md. $15 \mathrm{~cm}$. MN I. Fig. 37,3.

41. Størstedelen af et fint udført tragtbæger. Under randen ses et vandret bånd, indrammet af en vandret linie og en vinkellinie samt udfyldt med skrå indtryk. Ved hals/bugovergangen og nederst på bugen ses en vandret vinkellinie. Derimellem findes på den øverste del af bugen lodrette linier. Al ornamentikken er udført med et fintandet tandstokstempel. Md. ca. $14 \mathrm{~cm}$. Bd. ca. $5,0 \mathrm{~cm}$. Ca. $12 \mathrm{~cm} \mathrm{h.} \mathrm{MN} \mathrm{II} \mathrm{(tidlig} \mathrm{Ferslevstil).} \mathrm{Fig.} \mathrm{30,2.}$

42. Fragm. af et stort, groft tragtbæger. Under randen findes en indridset dobbeltvinkellinie. På den øverste del af bugen ses lodret afstribning. Md. ca. 29 cm. MN I-II. Fig. 29,2.

43. Størstedelen af et tragtbæger. Under randen ses en dobbeltvinkellinie. På den øverste del af bugen findes et mønster af lodrette, indridsede liniegrupper. Ornamentikken afsluttes nedadtil af en dobbeltvinkellinie. Md. $18 \mathrm{~cm}$. Bd. 7,0 cm. Ca. $20 \mathrm{~cm} \mathrm{h.} \mathrm{MN} \mathrm{I/II.} \mathrm{Fig.} \mathrm{30,3.}$

\section{Oskenbagre}

44. Størstedelen af et øskenbæger (pragtbæger). Det er under randen ornamenteret med 4 vandrette rækker af halvbuestik. Derunder ses på hals og bug et mønster af afvekslende lodrette, krydsskraverede bånd og lodrette 3-dobbelte bånd. Det midterste bånd i disse er udfyldt med en lodret vinkelrække; de omgivende med krydsskravering. Krydsskraveringen er lavet i tandstok. Øsknerne er ornamenteret med lodrette liniegrupper. Md. $28 \mathrm{~cm}$. MN Ib. Fig. 36,2.

\section{Cylinderhalsboegre}

45. Størstedelen af et cylinderhalsbæger, som under randen er ornamenteret med en vandret række korte, brede indstik. Der er tværstreger i randkanten. På den øverste del af bugen ses ligeledes en vandret række, dybt indstemplede skråstreger. Karret er revnet i brændingen og derefter klinket. Ca. $4 \mathrm{~cm}$ under randen og ved hals/bugovergangen ses $2 \times 2$ klinkningshuller på hver sin side af revnen. Over mundingen er lagt et nyt stykke ler til yderligere reparation. Md. 40,0 cm. MN I/II. Fig. 35,2.

Bagre med konkav hals

46. Fragm. af uornamenteret bæger med konkav hals og glattet overflade. Md. ca. $24 \mathrm{~cm}$. Udat. Fig. 34,8 .

47. Størstedelen af et uornamenteret bæger med konkav hals. Det har glattet overflade og stærkt markeret overgang fra hals til bug. Md. ca. $30 \mathrm{~cm}$. MN II(?). Fig. 35,1.

Sfariske skåle

48. Fragm. af uornamenteret, sfærisk skål. Md. ca. 34 cm. Udat. Fig. $37,8$. 


\section{Lerskiver}

49. Fragm. af lerskive; på den ene side langs kanten ornamenteret med en række flygtigt indstemplede, uregelmæssige indtryk. $22 \mathrm{~cm}$ i diam., ca. 1,0 cm t. MN I-II. Fig. 31,6.

50. Fragm. af uornamenteret lerskive. Ca. $20 \mathrm{~cm}$ i diam. og 1,1 cm t. Udat. Fig. 33,9.

51. Størstedelen af en uornamenteret lerskive. Ca. $23 \mathrm{~cm}$ i diam. og ca. 1,0 cm t. Udat. Fig. 30,1.

52. Fragm. af en uornamenteret lerskive. Ca. $22 \mathrm{~cm}$ i diam. og 1,4 cm t. Udat. Fig. 37,5.

53. Tre små fragmenter af en uornamenteret lerskive. Ca. $20 \mathrm{~cm}$ i diam. og ca. $1,1 \mathrm{~cm} \mathrm{t}$. Udat.

Ubestemmelige lerkar

54. Randskår af lerkar. Under randen ses 4 vandrette linier i henholdsvis falsk, beviklet snor og indridset. Derunder ses mindst en dobbelt vinkellinie. MN II. Fig. 31,2.

55. Randskår, hvorpå ses hængende trekanter, udfyldt med skrå cardiumindtryk. Fig. 31,3.

56. Fire randskår, hvorpå ses spor af skrå cardiumindtryk i et vandret bælte.

57. Et randskår. Under randen ses et vandret, krydsskraveret felt.

58. Randskår af lerkar, som under randen er ornamenteret med en vandret, indstemplet vinkellinie.

59. Randskår med mindst tre, indridsede vinkellinier under randen.

60. Ni randskår, hvorpå ses vandrette vinkellinier under randen.

61. To ornamenterede randskår.

62. 24 uornamenterede randskår af forskellige lerkar. Fig. 34,4.

63. 7 uornamenterede skår, de to randskår. Muligvis jernalder.

64. Tre halsskår med spor af lodrette liniegrupper.

65. Hals/skulderskår. På skulderen er karret ornamenteret med skråstreger. På halsen ses lodrette linier med tværstreger til siderne. Fig. 37,4.

66. Fragm. af en hals/bugovergang.

67. Hank, ornamenteret med lodrette liniegrupper i fin tandstok. Fig. 34,2.

68. To fragm. hanke ornamenteret med lodrette linier i beviklet snor, den ene ildmærket.

69. Flere hank- og sideskår, ornamenteret med groft indstemplede, vandrette vinkellinier.

70. Et sideskår, hvorpå ses indstemplede vinkellinier.

71. To bugskår, hvorpå ses lodrette, plastiske lister. Fig. 37,6.

72. Et sideskår, hvorpå ses en pålagt, plastisk liste.

73. To bugskår af et lerkar, som på bugen er ornamenteret med afvekslende, lodrette linier i tandstok og med lodrette, krydsskraverede bånd. MN Ib. Fig. 34,2.

74. To sideskår med grov, lodret afstribning.

75. 23 bugskår, hvorpå ses lodret afstribning.

76. 29 ornamenterede sideskår, som er så fragmenterede og forvitrede, at ornamentikkens art ikke kan bestemmes.

77. Fragmenter af 3 uornamenterede lerkar-underdele. Fig. 33,6.

78. 2 uornamenterede lerkarbunde.

79. Uornamenterede sideskår. 


\section{NOTER}

1) Jættestuen har nr. 21.01.08.86. Fundet opbevares på Nationalmuseet A 50.304. FS 1-111 (dele deponeret på ASR).

2) K. Ebbesen i tryk a.

3) K. Davidsen 1978: 180, nr. 28.

4) K. Ebbesen 1979.

5) K. Ebbesen 1993. S. Hansen 1993.

6) K. Ebbesen 1978.

7) K. Ebbesen 1978-1979.

8) A.B. Gebauer 1978: $137 \mathrm{ff}$.

9) K. Ebbesen 1979: $41 \mathrm{ff}$.

10) H. Berg og K. Ebbesen i tryk.

11) F. Kaul 1987: 71 ff. H. Berg og K. Ebbesen i tryk

12) På et sted ca. $600 \mathrm{mmod}$ øst (Spandet sg, sb. 43) skal der have været et underjordisk gravkammer, hvis sten er bortført. Ca. $1 \mathrm{~km}$ mod VNV ses på samme bakkeskråning tomten af en sløjfet høj (Spandet sg, sb. 69). Den er ca. $21 \mathrm{~m}$ i diameter og $0,85 \mathrm{~m}$ høj. Der er registrertet mange sten i højen, og der skal have været et stenkammer. Såvidt det er oplyst en mandslang kiste. Ingen af dem er dog sikre som megalitgrave.

13) Spandet sg, sb. 82 .

14) Højrup sg, sb. 80. NM A 38.875 .

15) Højrup sg, sb. 13.

16) Vodder sg, sb. 48

17) Seem sg, sb. 60. Fundet (NM A 37.902-6) er i 1938 indsendt af lodsejeren. K. Davidsen 1978: 114, fig. 57c. A.B. Gebauer 1978: App.A, nr. 4. K. Ebbesen 1978: fl. A nr. 114.

18) Gram sg, sb. 86.

19) Gram sg, sb. 87. K. Langenheim 1934: 43. H. Schwabedissen 1953: 32, T. 4,k-1.

20) Gram sg, sb. 62.

21) C.J. Becker 1954: 100 ff. N. Thomsen 1971: 5 ff. 1974: 5 ff. 1977: 5 ff. A.B. Gebauer 1978: 117 ff. K. Ebbesen 1978: Fl. A. 1979a: 51 ff. 1986: 118 ff. J. Hoika 1990.

22) Jerne sg, sb. 179. NM j. 534/52. C.J. Becker 1954: fig. 23. N. Thomsen 1971: 8 f. A.B. Gebauer 1978: App. A, nr. 5. K. Ebbesen 1978: fl. A nr. 115

23) N. Thomsen 1971: $19 \mathrm{f}$.

24) Grimstrup sg, sb. 41. FHM 1457. A.B. Gebauer 1978: 117 ff.

25) Borre, Aal sg, sb. 101. FHM 1669. J. Koch og A.B.Gebauer 1976: 12 ff.

26) Varde ldsg, sb. 32. NM A 19.566-77. S. Müller 1913: 263 ff. C.A. Nordman 1917: 87 ff. A.B. Gebauer 1978: App. nr. 11. K. Ebbesen 1978: fl.A. nr. 111.

27) Læborg sg, sb. 87. Anlægget er sløjfet i 1928. Højen var ca. $12 \mathrm{~m}$ i diameter. Heri fandtes en jættestue med kammer og gang. Kammeret var aflangt og orienteret $\varnothing-V$. Det var 2,65 m langt mod nord og 2,8 m langt mod syd. Det var 1,4 m bredt. Kammeret var bygget af 7 bæresten og 5 dæksten, som alle var afvæltede. Væggene var tætnet med småsten. I kammerets øst- og vestende stod 1 sten; nordvæggen var sat af 3 bæresten, mens sydvæggen var dannet af 2 sten, hvorimellem der fandtes en gangåbning. Den var $0,85 \mathrm{~m}$ høj; ca. $0,5 \mathrm{~m}$ bred foroven og $0,55 \mathrm{~m}$ bred for neden. Dækstenen over indgangen hvilede på gangens bæresten. Gangen var orienteret N-S. Den var 3,3 m lang, 0,5 m bred og 0,7 m høj. I gangens sider stod 4 sten mod vest og 3 sidesten mod øst. På højens sydside iagttoges 6 randsten.

28) Ved Gårde Skole, Tistrup sg (sb. 5. - FHM 1613) er endvidere undersøgt tomten af en meget ødelagt megalitgrav. Fundene omfatter bl.a. et par tragtbægre og fodskåle samt en lerske. Muligvis er der ligeledes her tale om et offerlag.

29) Brede sg, sb. 4 (NM j. 405/62). O. Voss 1963: 18. K. Davidsen 1978: 114, fig. 57a og p. 180, nr. 26. K. Ebbesen 1978: fl. A nr. $154 \mathrm{ff}$.

30) Bov, Burkal sg. K. Davidsen 1978: Pl. 109, b-e. K. Ebbesen 1978: Fl. A nr. 155.

31) Møgeltønder, sb. 20. I højen er nord for bundbrolægningen fundet en urne, sandsynligvis fra en sekundær begravelse.

32) H. Hinz 1954: 188 ff, Schwesing, Grabhügel 4-8. H. Schwabedissen 1953: $14 \mathrm{ff}$.

33) H. Hinz 1954: 194, T. 17 og 18.8-11. Grossteingrab 48.

34) H.J. Kühn 1990: 413 ff.

35) H. Hingst 1985: 57 ff. J. Hoika 1990: T. 8-9.

36) Jf. K. Ebbesen 1986: 117 ff; 1987. J. Hoika 1990: 53 ff.

37) F. Wibel 1869. H. Handelmann 1873; 1882. K. Kersten og P. la Baume 1958. Wennningstedt, Steingrab 85 og 91.

38) H. Schwabedissen 1953: 23 ff. K. Kersten og P. la Baume 1958: 365 ff. Archsum, Steingrab 71.

39) K. Kersten og P. la Baume 1958: Archsum, Steingrab 68 (Kolkingehoog) - Riesenbett 74. - Steingrab 76 (Merelmershoog). 
40) K. Kersten og P. la Baume 1958: Keitum, Grabhügel 42.

41) K. Kersten og P. la Baume 1958: Kampen, Steingrab 2, 78, 99 og 99. Tillige Kampen (Kupferkanne), Grabhügel Arla 44.

42) K. Kersten og P. la Baume 1958. K. Ebbesen 1987.

43) K. Kersten og P. la Baume 1958: Nieblum, Grabhügel 40; Utersum, Grabhügel 8 (Hünjbruatberg). J. Hoika 1977-78: 40 ff. H. Hingst 1985: 62 f. - Süderende, Grabhügel 3.

44) K. Kersten og P. la Baume 1958: 112 ff.

45) J.J.A. Worsaae 1865. S. Müller 1913: 197 f. J. Brøndsted 1932: 57 ff. P.V.Glob 1946.

46) K. Ebbesen 1985: tabel 3; 1986: 117 ff.

47) K. Ebbesen 199?

\section{LITTERATUR}

Baume, P. la og K. Kersten. 1958: Vorgeschichte der nordfriesischen Inseln. Neumünster 1958.

Becker, C.J. 1954: Die mittel-neolithischen Kulturen in Südskandiavien. Acta Archaeologica 25, 1954: 49-150.

Berg, H. \& K. Ebbesen i tryk: Keramikofre ved en langhøj i Frellesvig, Langeland. Vil fremkomme i Aarboger f. nord. Oldkynd. og Hist.

Brøndsted, J. 1932: Oldtidsminderne. G. Knudsen \& K. Kretzschnig (eds.). 1932: Sydslesvig I, Kbh. 1932: $57-$ 62.

Davidsen, K. 1973: Neolitiske lerskiver belyst af danske fund. Aarboger f. nord. Oldk. og Hist. 1973: 5-65.

- 1978: The Final TRB Culture in Denmark. Arkxologiske Studier V. Kbh. 1978.

Ebbesen, K. 1975: Die jüngere Trichterbecherkultur auf den dänischen Inseln. Arkæologiske Studier II. Kbh. 1975.

- 1978: Tragtbagerkultur $i$ Nordjylland. Nordiske Fortidsminder B 5. Kbh. 1978.

- 1979: Stordyssen $i$ Vedsted. Arkæologiske Studier VI. Kbh. 1979.

- 1979a: Nordvestjyllands dysser og jættestuer. Holstebro Museum, Årsskrift 1979: 51-102.

- 1984: Megalithic Graves in Schleswig-Holstein. Acta Archaeologica 55, 1984: 117-42.

- 1985: Fortidsminderegistrering i Danmark.

- 1987: Sydslesvigske oldtidsminder. Granseforeningens årbog 1987.

- 1993: Stendysser og jottestuer. Odense 1993.

- 199?: Megalithic Tombs in Denmark. Vil fremkomme.

Gebauer, A.B. 1978: Mellemneolitisk tragtbægerkultur i Sydvestjylland. Kuml 1978: 117-57.

Glob, P.V. 1946: Sydslesvigs Oldtid. Sydslesvig gennem tiderne. 1946.

Handelmann, H. 1873: Die amtlichen Ausgrabungen auf Sylt 1870; 1871 und 1872. Kiel 1873.

- 1882: Die amtlichen Ausgrabungen auf Sylt 1873; 75; 77 und 1880. Kiel 1882.

Hansen, S. 1993: Jottestuer i Danmark. Hørsholm 1993.

Harck, O. et alii 1974: Grossteingräber am Sylter Westrand. Offa 31, 1971: 126-32.

Hingst, H. 1985: Grossteingräber in Schleswig-Holstein. Offa 42, 1985: 57-112.

Hinz, H. 1954: Vorgeschichte des nordfriesischen Festlandes. Neumünster 1954.

Hoika, J. 1978-79: Funde aus einem Megalitgrab in Kampen, Sylt. Kölner Jahrbuch 1978-79: 40-53.

- 1990: Megalithic Graves in the Funnel Beaker Culture of Schleswig-Holstein. Przeglad Archeologiczny 37, 1990: 53-119.

Kaul, F. 1987: Neolitiske gravanlæg på Onsved Mark, Horns Herred, Sjælland. Aarbøgerf. nord. Oldk. og Hist. 1987: 27-83.

Koch, J. og A.B. Gebauer 1976: En dysse fra Aal sogn. Mark og Montre 1976: 12-24.

Kühn, H.J. 1990: Rantrum (LA 1). Offa 1990: 423-26.

Langenheim, K. 1935: Die Tonware der Riesensteingräber in Schleswig-Holstein. Neumünster 1935.

Müller, S. 1913: Sønderjyllands Stenalder. Aarbøger f. nord. Oldk. og Hist. 1913: 169-322.

Nordman, C.A. 1917: Gånggrifter i Danmark. Nya fund. Nordiske Fortidsminder II,2. Kbh. 1917.

Schwabedissen, H. 1953: Fruchtschalen aus Schleswig-Holstein. Offa 12, 1953: 14-63.

Sprockhoff, E. 1966: Atlas der Megalithgräber Deutschlands I. Schleswig-Holstein. Bonn 1966

Thomsen, N. 1971: Tragtbægerkultur i Sydvestjylland. 1. Mark og Montre 1971: 5-12.

- 1974: Tragtbægerkultur i Sydvestjylland. 2. Mark og Montre 1974: 5-16.

- 1977: Tragtbægerkultur i Sydvestjylland. 3. Mark og Montre 1977: 5-17.

Voss, O. 1963: Steneng. Skalk 1963,1: 18-19.

Wibel F. 1869: Der Gangbau der Denghoogs bei Wenningstedt am Sylt. 29. Kieler-Bericht 1869: 1-88.

Worssae, J.J.A. 1865: Om Slesvig eller Senderjyllands Oldtidsminder. En sammenlignende Undersøgelse. Kbh. 1865. 


\section{A Passage Grave at Fjersted, SW Jutland}

The passage grave is situated ca. 10 km E of Gram on the west Schleswig moraine island. The subsoil is yellow sand and there are flooded depressions around the site.

The excavation took place in 1955-59. It was found that the western part of the chamber was destroyed, but the lowest 15-2() $\mathrm{cm}$ were intact and the extraction holes of the uprights could be determined. The surviving undis-turbed chamber fill was of homogeneous yellow, nearly whiteish sand passing gradually downwards into natural subsoil sand. Its exact base could not be distinguished. The only finds were a few poorly preserved human bones, a double-axe shaped amber bead (MN Ia-V), a spool-shaped amber bead (MN IA-V), most of a shouldered bowl from MN II, a barrelshaped pot from $\mathrm{MN} \mathrm{V}$, and a decorated open bowl perhaps from the same period. The passage grave must thus have been used for burials at least twice - in MN II and in MN V. Probably it was used more often - perhaps also in $\mathrm{MN}$ Ib.

The exact floor level could not be determined in the passage either, but the bottom probably sloped down towards the chamber. The fill was similar to the chambers's. The outer end of the passage was closed by a pile of headsized stones. This blocking dated probably from $M N V$, while the original doorstone had been in line with the kerb and now lay flat on the pile.

Outside the entrance was a layer of stones covering an abundant layer of pottery offerings. Stones and sherds were densest $W$ and SW of the entrance. Two amber beads and a transverse arrowhead were also found in this layer.

The burial chamber lay in the southern part of a mound of sand standing on the original ground surface, originally with a stone kerb. The floor of the chamber had been sunk ().(6(). $8 \mathrm{~m}$ into the natural subsoil.

The plan of the chamber was oval with EW orientation, length ca. $3.8 \mathrm{~m}$, breadth 1.8 $\mathrm{m}$, and height 1.1-1.3 $\mathrm{m}$. There were 11 uprights, of which 8 survived in place. Dry walling was preserved at some place, and both the chamber and passage were surrounded by a packing of stones and clay mixed with shatte- red flint. There had originally been three transversely placed capstones. The passage was $3 \mathrm{~m}$ long and ().6 $\mathrm{m}$ wide, and joined the middle of the southern side of the chamber. Three uprights survived in place of its western and 4 of its eastern side. There may have been a sillstone at its inner end.

The offered pottery at the entrance of the tomb derived from at least 51 different vessels. These were 15 pedestal bowls (one with remarkably low pedestal), 5 Troldebjerg bowls, 1) funnel beakers, 1 richly decorated lugged beaker, 4 funnel bowls, 3 pottery spoons (one made probably by the same potter as the pedestal bowls), 3 shouldered vessels, 2 beakers with concave neck, 1 repaired beaker with cylindrical neck, 1 spherical bowl, 5 clay discs, and 1 indeterminate pot.

The pottery is datable to MN Ib-II, and the Troldebjerg (or Gingst) style is not represented. Half the material (25 pots) can be dated to MN Ib, while 6 pots ( 1 funnel beaker, 2 funnel bowls, 1 shouldered bowl, 1 Troldebjerg bowl, and 1 indeterminate form) can be dated to $\mathrm{MN}$ II. Three of these are decorated in the early Ferslev style. The sherds of the different pots lay mixed, but usually those of any one vessel had a limited range. It could therefore be established where many of the pots had been placed. Most of the pottery was found SW and W of the entrance, but at least 12 pots had been placed $\mathrm{E}$ of the entrance, some in front of, others on top of or behind the kerbstones. There was a tendency for the pedestal bowls to be near the entrance. (Otherwise there was no systematic pattern of placing. Sherds of the late pottery were found throughout the offering layer. The late pots had been placed in front of the entrance and on both its sides on top of and in front of the kerbstones. The case was the same with the pots decorated in Klintebakke style.

The number of funnel beakers, especially those the size of drinking beakers, was remarkably low. The number of pedestal bowls on the other hand was very high $(34 \%$ - the highest ratio in the whole of northern Europe). Pedestal bowls and clay spoons are generally regarded as ritual pottery connected especially with burial cult. It is clear that repeated depositions 
of one or more pots had taken place in the vicinity of the tomb entrance. Many of these vessels were without practical function and were probably made for this ritual only.

The Fjersted passage grave lies geographically somewhat isolated, as do most megalithic tombs in western Jutland and Schleswig-Holstein. The distance in any direction to the next megalithic tomb is $4-10 \mathrm{~km}$. This is one of the few passage graves and few offering layers known from SW Jutland and western Schleswig. The nearest other passage grave is "Roverstuen" in Lindet wood. Further passage graves or offering layers are known from Veldbæk, Borre, and Grimstrup Krat. Around Esbjerg there are Mejls near Varde, Nyby near Lxborg, Steneng at Bredebro, Bov, and Møgeltønder. East of Husum near the town of Schleswig six destroyed megaliths have been recorded. Most were passage graves or great dolmens with offering layer. Three passage graves been recorded on Föhr, and on Sylt there are no less than twelve passage graves or offering layers. Ca. 4()$^{*} \%$ of the passage graves in SW Jutland and western Schleswig lie in a small geographical area on this island's hummocky moraine. The distance from Fjersted to this remarkable concentration, whose importance has not earlier been noted in Danish archaeology, is 4() $\mathrm{km}$ as the crow flies.
The number of recorded passage grave appears to be proportional to the number originally existing, and the same can be said of their geographical distribution. The presence of passage graves and offering layers can therefore be seen as a reflection of settlement and population density at around 32()() B.C. (MN Ib).

In SW Jutland and western Schleswig there were considerably greater distances between the small cultivated areas where the inhabitants lived than there was further east in the Baltic area. There may nevertheless have been places with many passage graves and probably many people.

The basic settlement pattern was thus uniform throughout southern Scandinavia and northern Germany. The same may be said of the offering rituals at passage graves and great dolmens. Clear shared features in pottery style can be seen joining eastern and western Jutland together. Hence it may be concluded that society had the same form of organization in SW Jutland and western Schleswig as in the rest of Demmark. The Fjersted passage grave and its offering layer is the first evidence of social differentiation in Denmark. Like the other passage graves it was built as a place of burial and ritual for the Stone Age chieftains and their families.
Klaus Eblesen
Institut for Arkæologi og Etnologi
Københavns Universitet

Oversattelse: David Liversage 